\title{
HYDROLOGIC PROVINCES OF MICHIGAN
}

\author{
U.S. GEOLOGICAL SURVEY
}

Water-Resources Investigations Report 91-4120

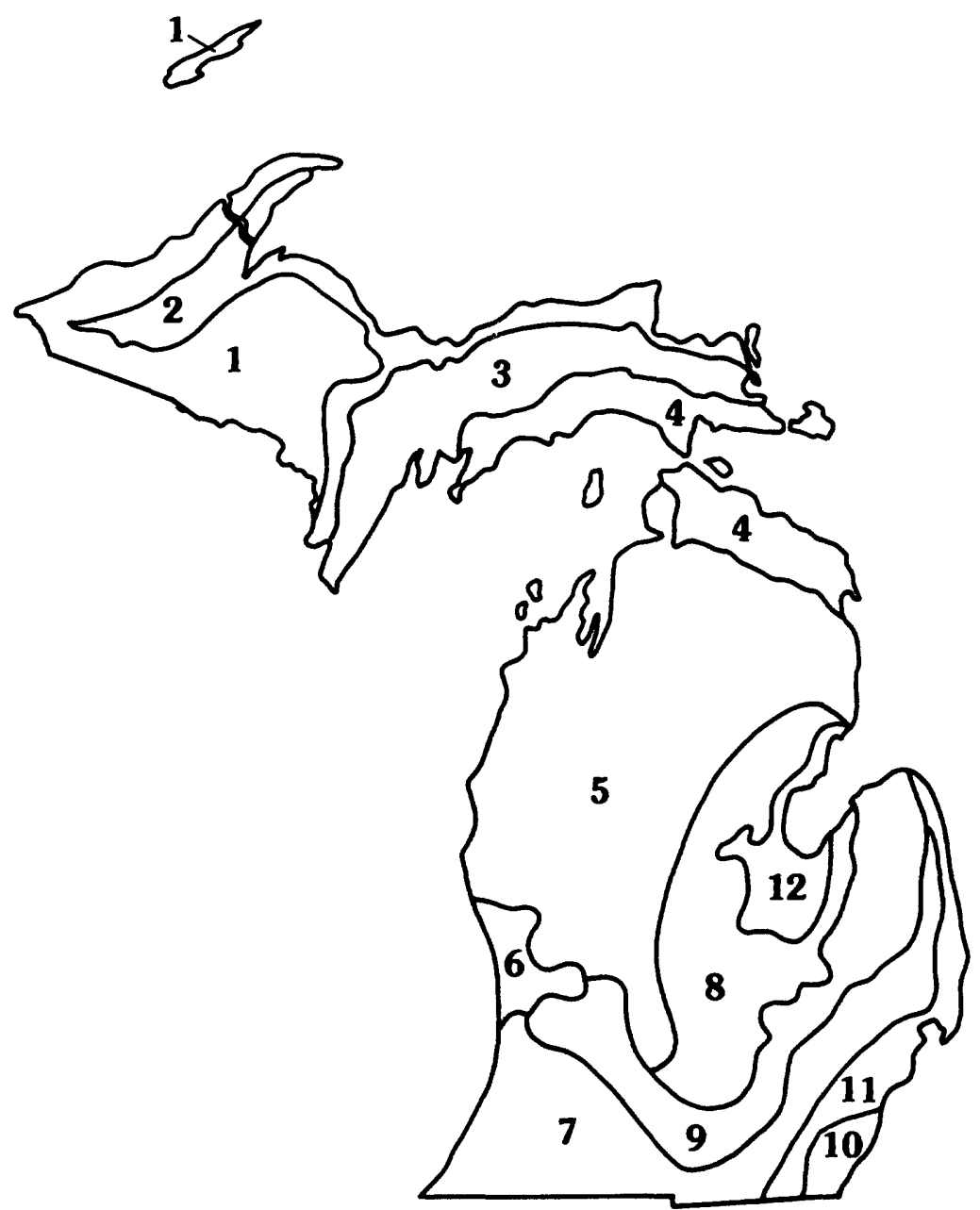

Prepared in cooperation with the

MICHIGAN DEPARTMENT OF NATURAL RESOURCES GEOLOGICAL SURVEY DIVISION 
HYDROLOGIC PROVINCES OF MICHIGAN

By S.J. Rheaume

U.S. GEOLOGICAL SURVEY

Water-Resources Investigations Report 91-4120

Prepared in cooperation with the

MICHIGAN DEPARTMENT OF NATURAL RESOURCES

GEOLOGICAL SURVEY DIVISION

Lansing, Michigan

1991 
U.S. DEPARTMENT OF THE INTERIOR

MANUEL LUJAN, JR., Secretary

U.S. GEOLOGICAL SURVEY

Dallas L. Peck, Director

For additional information

write to:

District Chief

U.S. Geological Survey

6520 Mercantile Way, Suite 5

Lansing, MI 48911
Copies of this report can

be purchased from:

U.S. Geological Survey

Books and Open-File Reports Section

Federal Center, Building 810

Box 25425

Denver, Co 80225-0425 


\section{CONTENTS}

Page

Abstract -

Introduction - 1

Purpose and scope -

Methods of investigation

General description of Michigan

Hydrologic provinces -

Province 1--Western Upper Peninsula

Physical setting - 16

Surface water - 19

Availability - 19

Quality - 19

Ground water - 20

Availability - 20

Quality - 20

Province 2--Northern Upper Peninsula

Physical setting - 21

Surface water - 21

Availability - 21

Quality

Ground water - 22

Availability _- 22

Quality - 23

Province 3--East-Central Upper Peninsula

Physical setting - 23

Surface water - 23

Availability 24

Quality - 24

Ground water - 24

Availability - 25

Quality - 25

Province 4--Northern Lower and southeastern Upper Peninsula - - 25

Physical setting - 26

Surface water -26

Availability - 26

Quality - 27

Ground water - 27

Availability - 27

Quality - 28

Province 5--North-Central Lower Peninsula

Physical setting - 28

Surface water - 29

Availability - 29

Quality - 29

Ground water - 30

Availability - 30

Quality 30 
Province 6--West-Central Lower Peninsula -- 30

Physical setting - 30

Surface water - 31

Availability

Quality - 31

Ground water - 31

Availability - 32

Quality - 32

Province 7--Southern Lower Peninsula - 32

Physical setting - 33

Surface water - 33

Availability - 33

Quality - 33

Ground water - 34

Availability - 34

Quality - 34

Province 8--Central Lower Peninsula - 35

Physical setting - 35

Surface water - 35

Availability - 35

Quality - 36

Ground water -- 36

Availability - 36

Quality -- 37

Province 9--South-Central Lower Peninsula - 38

Physical setting - 38

Surface water - 38

Availability - 38

Quality - 39

Ground water - 39

Availability - 40

Quality - 40

Province 10--Southeastern Lower Peninsula -- 40

Physical setting - 41

Surface water - 41

Availability - 41

Quality -- 41

Ground water - 42

Availability - 42

Quality - 42

Province 11--Eastern Lower Peninsula - 42

Physical setting - 43

Surface water - 43

Availability - 43

Quality - 43

Ground water - 44

Availability - 44

Quality - 44 
CONTENTS--Continued

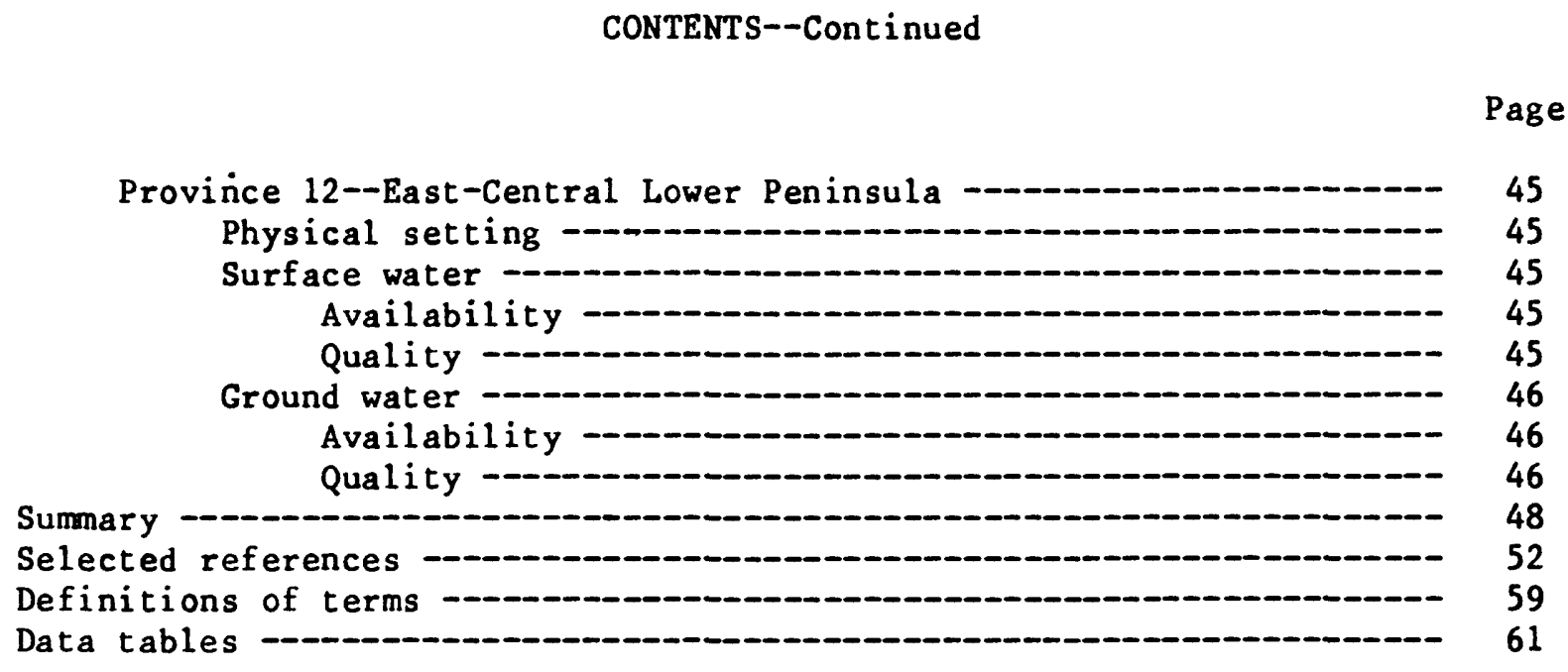




\section{ILLUSTRATIONS}

Page

Plate 1. Map showing hydrologic provinces of Michigan In pocket

Figures 1-12. Maps showing:

1. Great Lakes basin boundary and physiographic divisions and subdivisions of Michigan - 4

2. Average annual precipitation 5

3. Average annual runoff 5

4. Major drainage basins in Michigan 6

5. Average discharge of streams in Michigan

6. Areas where principal bedrock aquifers are exposed or directly underlie glacial deposits - 9

7. Bedrock stratigraphy of Michigan - 10

8. Potential yield of ground water from wells in glacial deposits - 13

9. Potential yield of ground water from wells in bedrock ---- 14

10. Approximate depth from land surface to base of fresh ground water - 15

11. Locations of streamflow and surface-water-quality sampling sites --

12. Locations of selected ground-water-quality sampling sites -_-_-

TABLES

Table 1. Selected streamflow characteristics of major rivers in Michigan -

2. Physical and chemical characteristics of streams during low flow, 1974-89

3. Median values of selected chemical and physical characteristics of ground water, by hydrologic province and aquifer -- 


\section{CONVERSION FACTORS AND VERTICAL DATUM}

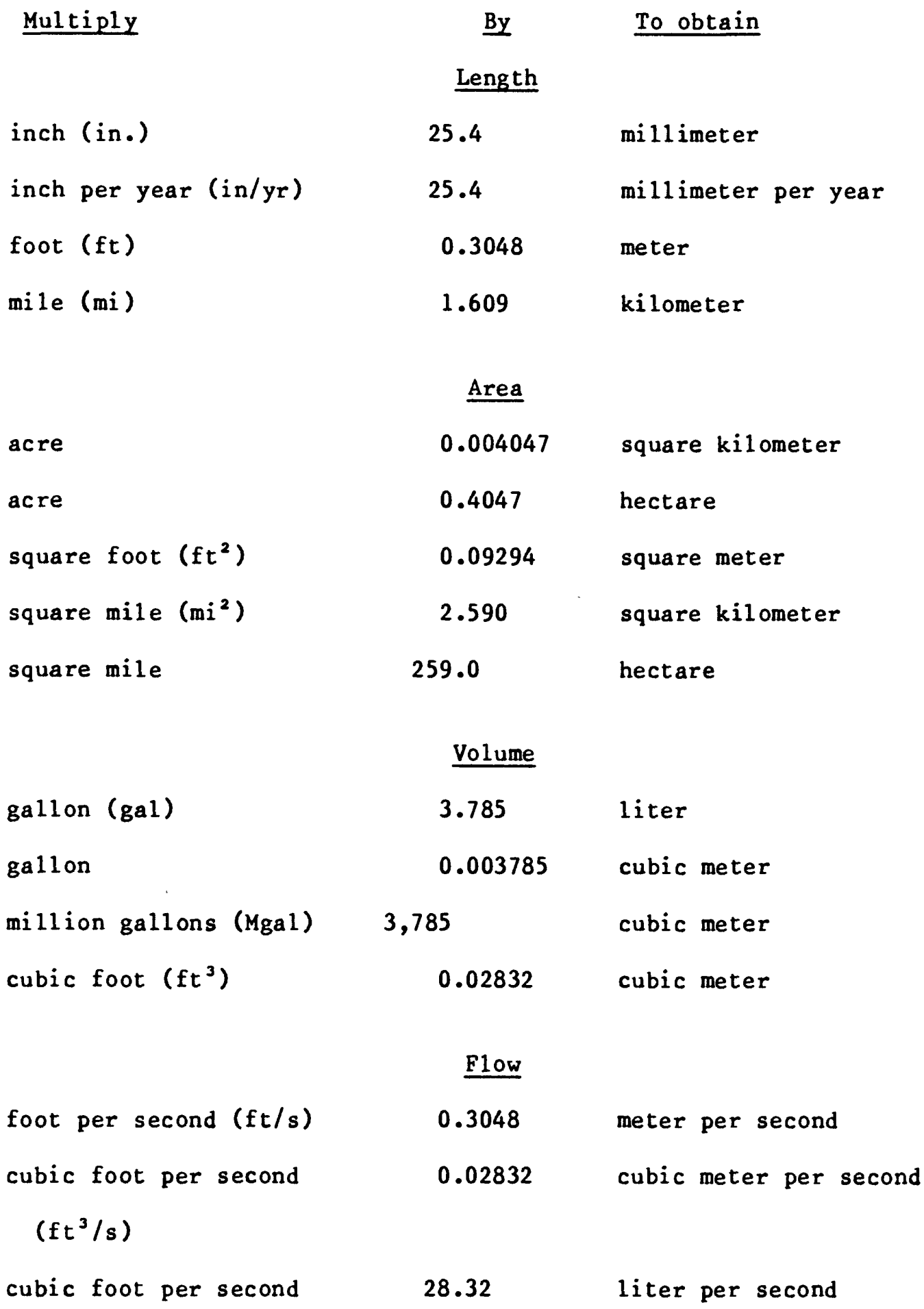


CONVERSION FACTORS AND VERTICAL DATUM--Continued

$\begin{array}{lcc}\text { Multiply } & \text { By } & \text { To obtain } \\ \text { gallon per minute (gal/min) } & 0.06308 & \text { liter per second } \\ \begin{array}{l}\text { million gallons per day } \\ (\text { Mgal/d) }\end{array} & 0.04381 & \text { cubic meters per day }\end{array}$

\section{Transmissivity}

foot squared per day $\quad 0.09290 \quad$ meter squared per day $\left(f t^{2} / d\right)$

\section{Temperature}

Degree Celsius $\left({ }^{\circ} \mathrm{C}\right)$ may be converted to degree Fahrenheit $\left({ }^{\circ} \mathrm{F}\right)$ by use of the following equation:

$$
{ }^{\circ} \mathrm{F}=\left(1.8 \times{ }^{\circ} \mathrm{C}\right)+32
$$

The following abbreviations are also used in this report:

microgram per liter ( $\mu g / L)$

microsiemens per centimeter at 25 degrees Celsius $(\mu \mathrm{S} / \mathrm{cm})$

milligrams per liter (mg/L)

Sea level: In this report, "sea level" refers to the National Geodetic Vertical Datum of 1929 (NGVD of 1929)--a geodetic datum derived from a general adjustment of the first-order level nets of the United States and Canada, formerly called Sea Level Datum of 1929. 


\section{HYDROLOGIC PROVINCES OF MICHIGAN}

by S.J. RHEAUME

ABSTRACT

This report presents the results of a study by the U.S. Geological Survey, in cooperation with the Michigan Department of Natural Resources, Geological Survey Division, to describe the statewide hydrologic variations in Michigan's water resources. Twelve hydrologic provinces, which are based on similarities in aquifer lithology, yield, recharge, and ground-water- and surface-water-quality data, are described. The definition of statewide hydrologic characteristics and the delineation of hydrologic provinces improves the understanding of Michigan's water resources and provides a firm basis for realistic water-manangement decisions.

The 12 provinces identified areas where bedrock aquifers provide most of the potable ground water (five provinces), where glacial-deposit aquifers provide most of the potable ground water (three provinces), and where problems with water quantity and (or) quality have limited the use of ground water as a water supply (four provinces). Subprovinces are defined on the basis of regional surface-water flow directions toward each of the Great Lakes.

\section{INTRODUCTION}

The hydrologic features of Michigan are quite variable statewide. In some areas of the State, abundant supplies of ground water and surface water of potable quality are available; but, in other areas, suitable water supplies are difficult to obtain. Although natural ${ }^{1}$ surface-water quality does not differ greatly statewide, variations in geology appear to be the primary cause of differences in natural ground-water quality across the State (Cummings, 1989 , p. 1). At some locations, the low permeability of the geologic deposits restricts the yield of wells. In other areas, saline water is near the land surface.

Although geologic maps of glacial deposits and bedrock lithologies are available, maps delineating hydrologic characteristics and their effect on availability and quality of the State's water supply had not previously been prepared. This investigation, a cooperative effort of the Michigan Department of Natural Resources, Geological Survey Division, and the U.S. Geological Survey, was done to define these hydrologic variations in water quantity and

1 The term "natural" is used to characterize water exhibiting no readily detectable modification by human activity. It is probable that few, if any, of the waters normally sought as supplies are completely free of effects of human activities. 
quality statewide and group areas of similar hydrologic characteristics into hydrologic provinces. The investigation required an assessment of aquifer thickness, lithology, yield, recharge, surface-water availability, and groundwater and surface-water-quality data. The definition of hydrologic characteristics statewide and the delineation of hydrologic provinces improves the understanding of Michigan's water resources and provides a firm basis for realistic water-management decisions.

\section{Purpose and Scope}

This report, which is based on information from published reports and unpublished file data of the Michigan Department of Natural Resources, Geological Survey Division, and of the U.S. Geological Survey, documents the delineation and description of 12 hydrologic provinces in Michigan. Much of the stratigraphic nomenclature, especially that in figure 7, follows the usage of the Michigan Department of Natural Resources, Geological Survey Division. Data on physical setting, surface-water and ground-water resources, and water quality for each of the hydrologic provinces were compiled and included in this report.

\section{Methods of Investigation}

Michigan was divided into 12 hydrologic provinces on the basis of similar hydrologic characteristics ( $\mathrm{pl}$. 1). As an initial step in defining these hydrologic provinces, principal bedrock aquifers were delineated on state maps of bedrock type by Milstein (1987) and Reed and Daniels (1987); and maps of yield by Twenter (1966a). Province boundaries were adjusted by overlaying maps of Quaternary geology by Martin (1955, 1957a) and Farrand and Bel1 (1984) and delineating additional principal glacial-deposit aquifers on maps of thickness by Passero and others (1981); and maps of yield by Twenter (1966b). Province boundaries were further readjusted on the basis of analyses of ground water from 354 wells sampled by the U.S. Geological Survey from 1977 through 1988 (Huffman, 1978-86, 1988; Huffman and Whited, 1988; Dannemiller and Baltusis, 1990). Areas were identified where ground water contained high dissolved-solids concentrations or where major differences in the natural ground-water quality were noted.

Analyses of natural surface-water quality revealed little variation statewide, so no further attempts to readjust boundaries were made; however, subprovinces were defined on the basis of regional surface-water flow to each of the Great Lakes ( $\mathrm{pl}, 1$ ). 


\section{GENERAL DESCRIPTION OF MICHIGAN}

Michigan lies entirely within the Great Lakes basin (fig. 1) and is divided into the Upper and Lower Peninsula. The two principal physiographic divisions in Michigan are the Superior Upland in the western Upper Peninsula and the Central Lowland in the remainder of the State. The Superior Upland is underlain by igneous, metamorphic, and sedimentary bedrock of Precambrian age. The Central Lowland is underlain by sedimentary bedrock of Precambrian, Paleozoic, and Mesozoic age. Glacial deposits of Pleistocene age cover most of the State. Topography ranges from level to gently rolling in the eastern part of the Upper Peninsula and southern part of the Lower Peninsula to hilly and rugged in the western part of the Upper Peninsula and the north-central part of the Lower Peninsula.

The climate of Michigan is affected by the surrounding Great Lakes. The lakes have a stabilizing effect on temperature, and, because of prevailing westerly winds, winters are milder and summers are cooler than in other States at identical latitudes.

Precipitation averages about 31 in. annually (National Oceanic and Atmospheric Administration, 1986) ( $\mathrm{fig}$. 2). Annual snowfall ranges from 160 in. in the western part of the Upper Peninsula to 30 in. in the southeastern part of the Lower Peninsula (Miller and Twenter, 1986, p. 277).

Runoff is geographically variable ( $\mathrm{fig}$. 3 ); it is as much as $20 \mathrm{in} / \mathrm{yr}$ in areas of heavy snowfall. Highest monthly runoff generally is during March, April, and May, when snowmelt and rainfall saturate soils (Miller and Twenter, 1986, p. 277).

Annual recharge to unconfined aquifers in Michigan ranges from 3 to $18 \mathrm{in} / \mathrm{yr}$ (Grannemann and others, 1985, p. 256). Some recharge moves to deep aquifers; however, most recharge flows from shallow aquifers to nearby streams and accounts for about 55 percent of the State's streamflow (Grannemann and others, 1985, p. 256).

Michigan borders nearly 20 percent of the world's fresh surface water; the State boundary includes about $3,000 \mathrm{mi}$ of shoreline along the Great Lakes. About 11,000 inland lakes, which total $1,150 \mathrm{mi}^{2}$ in area, are distributed throughout Michigan. There are 242 streams, whose combined length is 36,350 mi, that flow into the Great Lakes (Miller and Twenter, 1986, p. 277). The State's major drainage basins are shown on figure 4. Average discharge of major streams within those basins is shown in figure 5 .

Freshwater withdrawals from surface-water and ground-water sources average about $12,000 \mathrm{Mgal} / \mathrm{d}$ (Sweat, 1990, p. 305). The majority of Michigan's population ( 57 percent) depend on surface water from the Great Lakes for water supply. Most large municipal withdrawals are in the heavily populated counties in the southern part of the Lower Peninsula and are from surfacewater sources. The remainder of the state's population depends primarily on ground water for its water supply. 


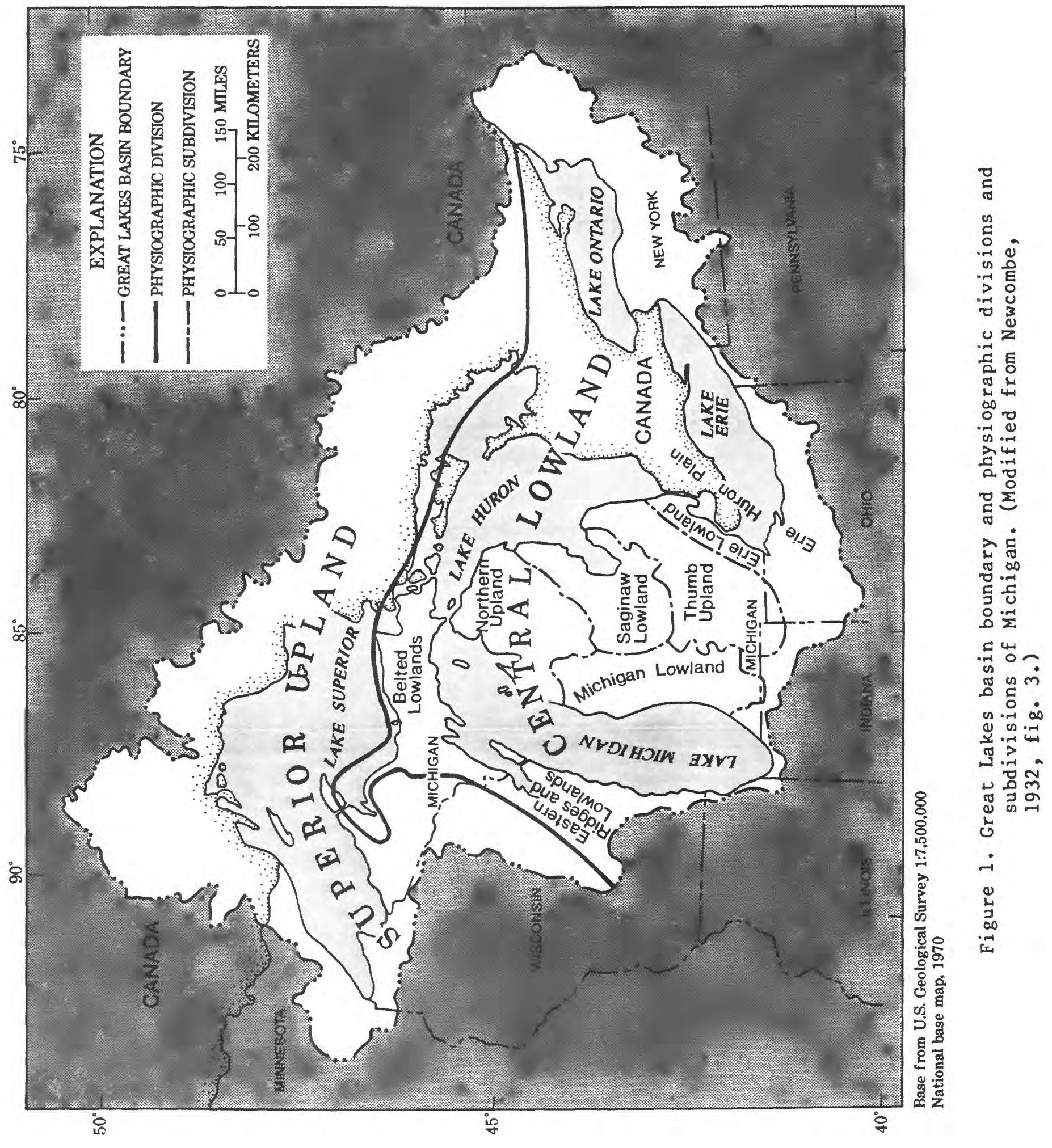


Figure 2. Average annual precipitation. (Data from National Oceanic and Atmospheric Administration, 1986.)

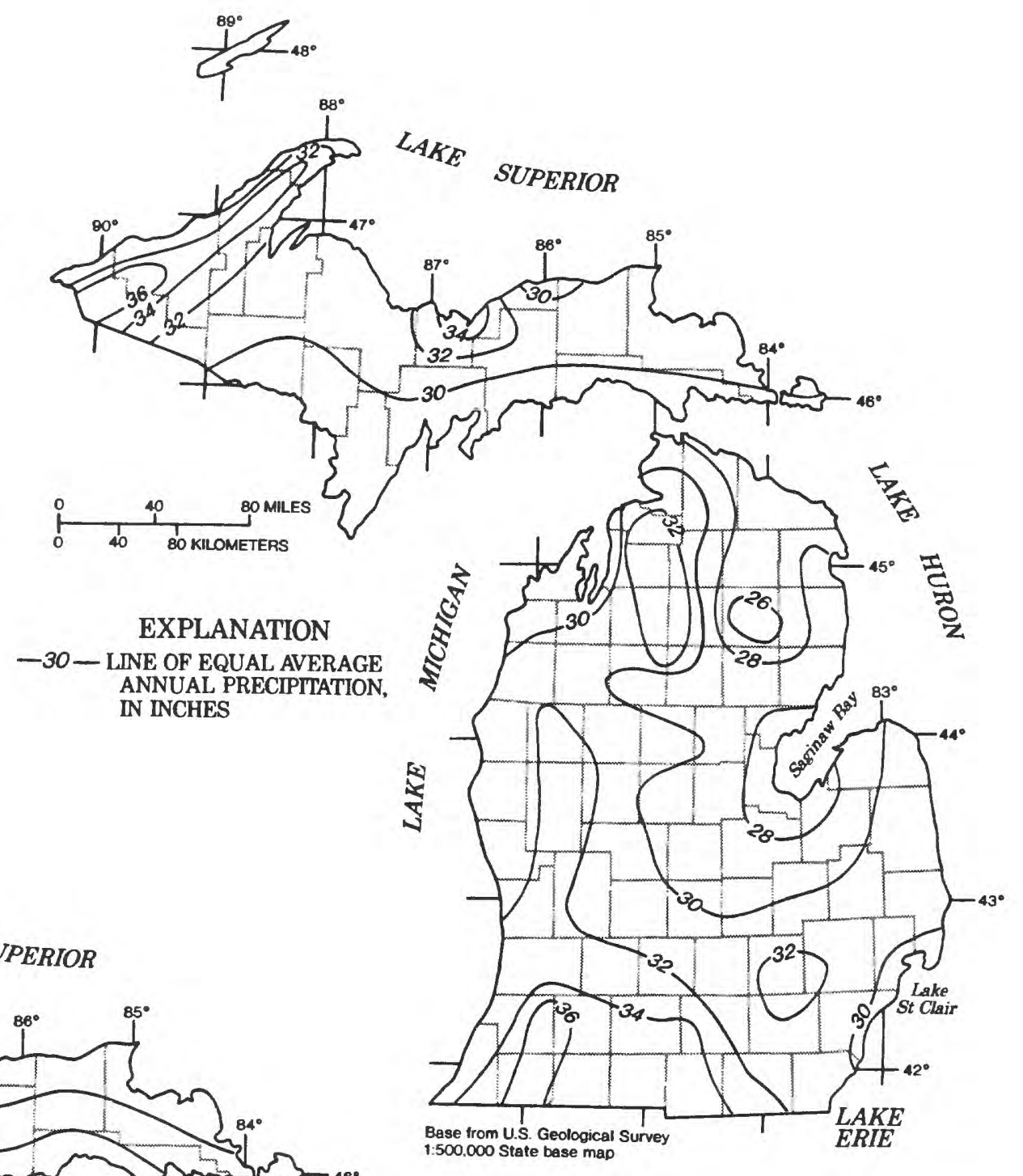

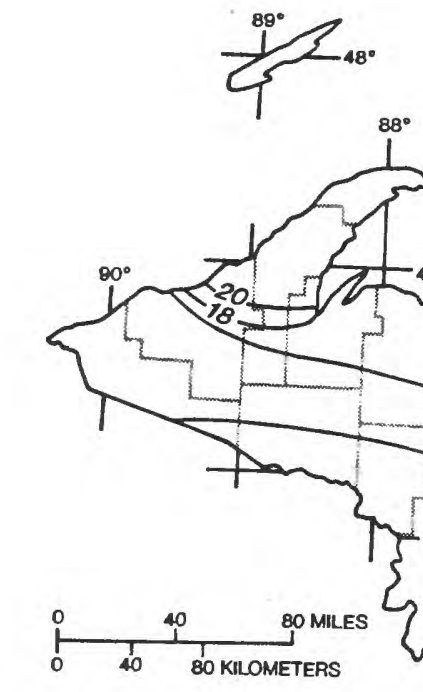

\section{EXPLANATION}

-18- LINE OF EQUAL AVERAGE ANNUAL RUNOFF, IN INCHES $\angle A K E$

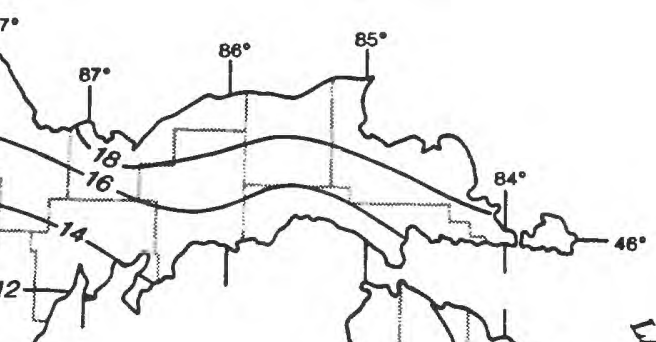

Figure 3. Average annual runoff. (From Miller and Twenter, 1986, fig. 1.) 


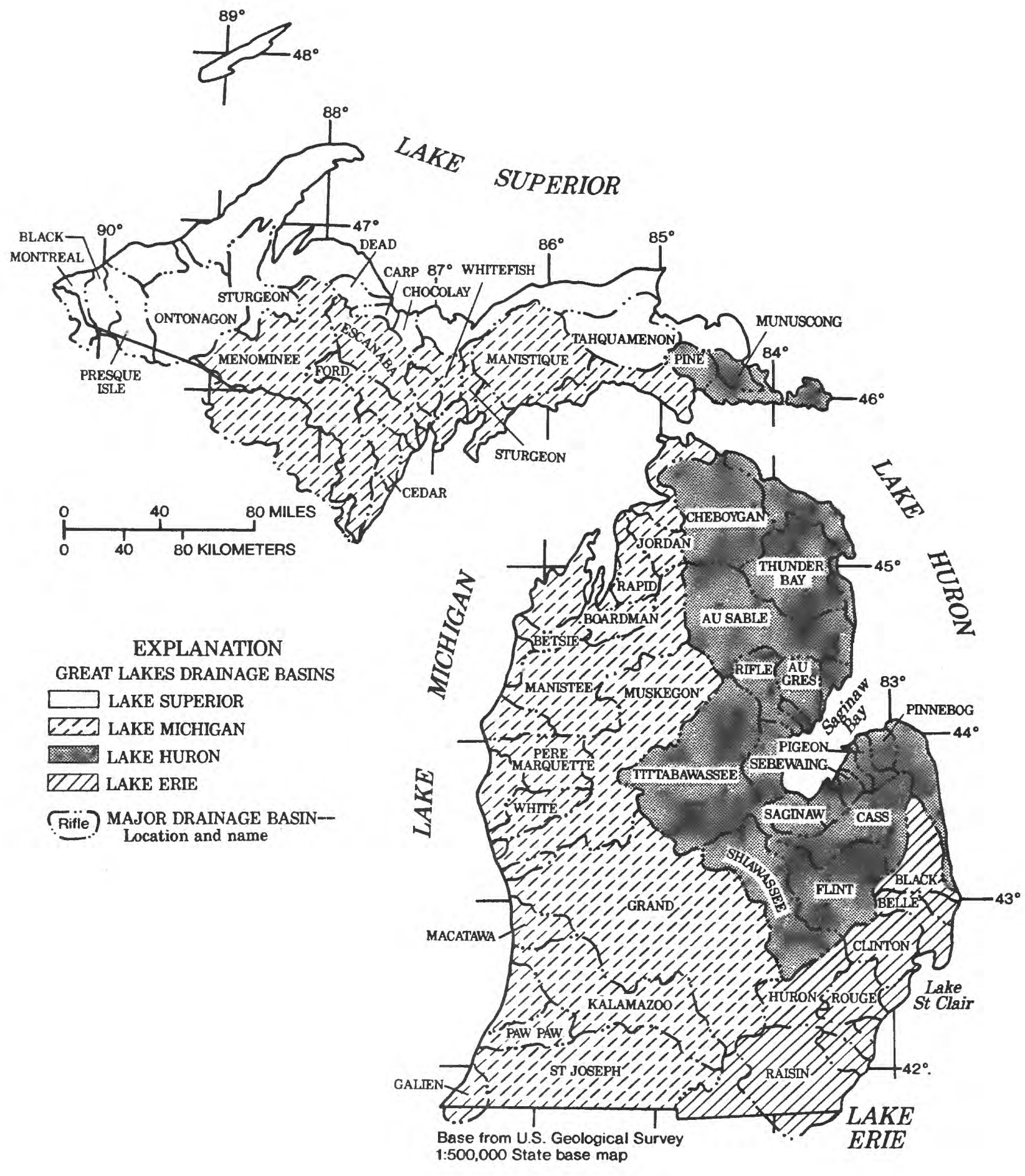

Figure 4. Major drainage basins in Michigan. 


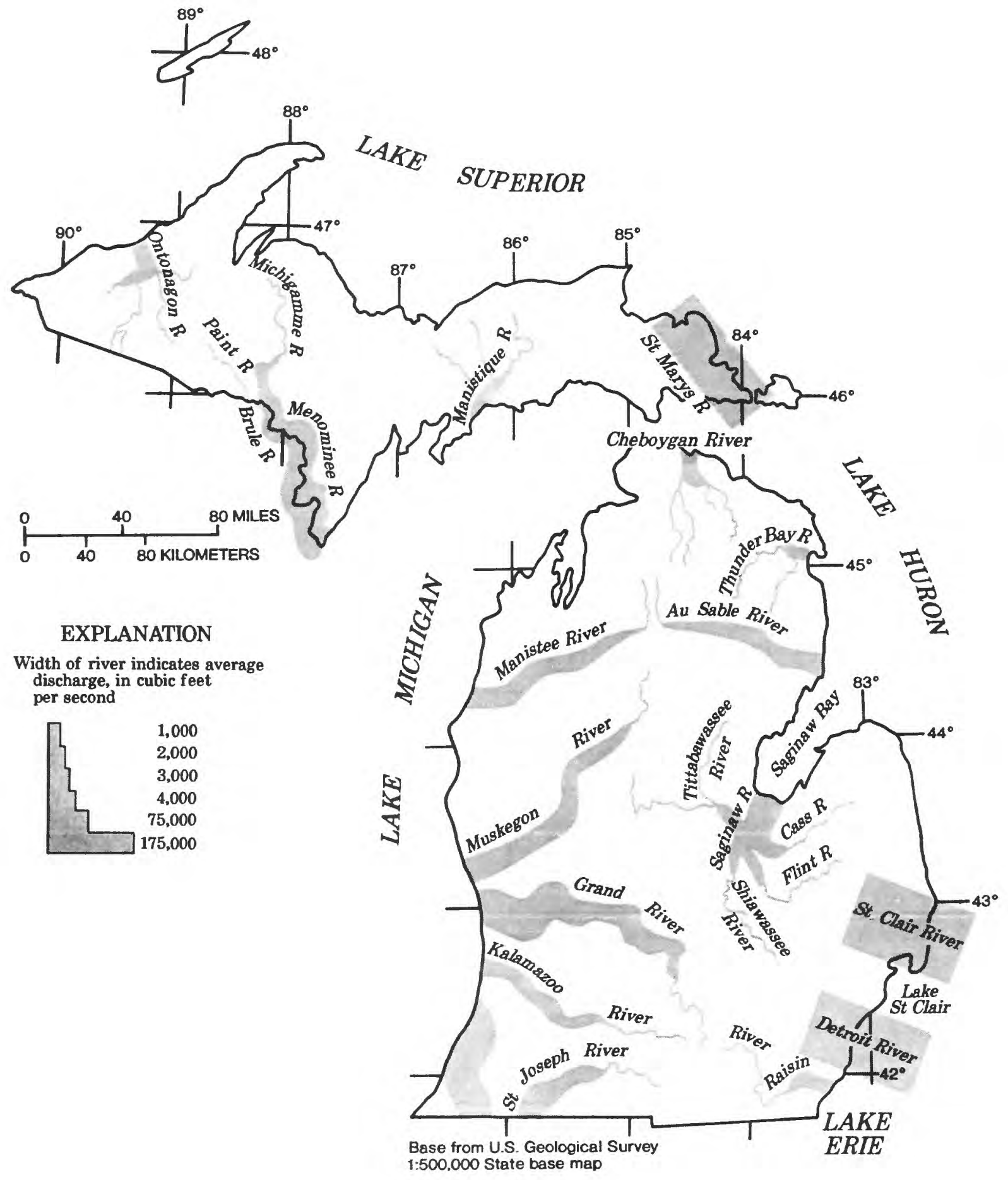

Figure 5. Average discharge of streams in Michigan. (Modified from Miller and Twenter, 1986, fig. 1.) 
The principal aquifers in Michigan consist of glacial deposits and sedimentary bedrock. The sedimentary bedrock deposits and their stratigraphic relations are shown in figures 6 and 7 . Potential yield of ground water from wells in glacial deposits is shown in figure 8 . Potential yield of ground water from wells in bedrock is shown in figure 9.

In the glacial-deposit aquifers, yields generally are largest from outwash and glaciofluvial deposits; they range from about 1 to $1,000 \mathrm{gal} / \mathrm{min}$. Lacustrine sand aquifers typically yield 80 to $500 \mathrm{gal} / \mathrm{min}$, and till aquifers yield 5 to $200 \mathrm{gal} / \mathrm{min}$.

Among bedrock aquifers, the Mississippian and Pennsyl vanian rocks in the Lower Peninsula are the most productive; yields commonly range from 100 to $1,000 \mathrm{gal} / \mathrm{min}$. In the Upper Peninsula, Silurian and Devonian rocks yield 10 to $100 \mathrm{gal} / \mathrm{min}$, Ordovician rocks yield 50 to $500 \mathrm{gal} / \mathrm{min}$, and Precambrian and Cambrian rocks yield 5 to $100 \mathrm{gal} / \mathrm{min}$.

Throughout the State, saline water underlies freshwater at depths ranging from about 100 to $900 \mathrm{ft}$ (Grannemann and others, 1984, p. 255) (fig. 10).

Near Lakes Erie, St. Clair, and Huron, and near Saginaw Bay, saline water lies at an average depth below land surface of about $200 \mathrm{ft}$. In some areas in west-central and southwestern Michigan, saline water is also within $200 \mathrm{ft}$ of the land surface. In the northwestern part of the Lower Peninsula, however, the depth to saline water is as much as $900 \mathrm{ft}$. In much of the Upper Peninsula, the depth to saline water is about $400 \mathrm{ft}$. 


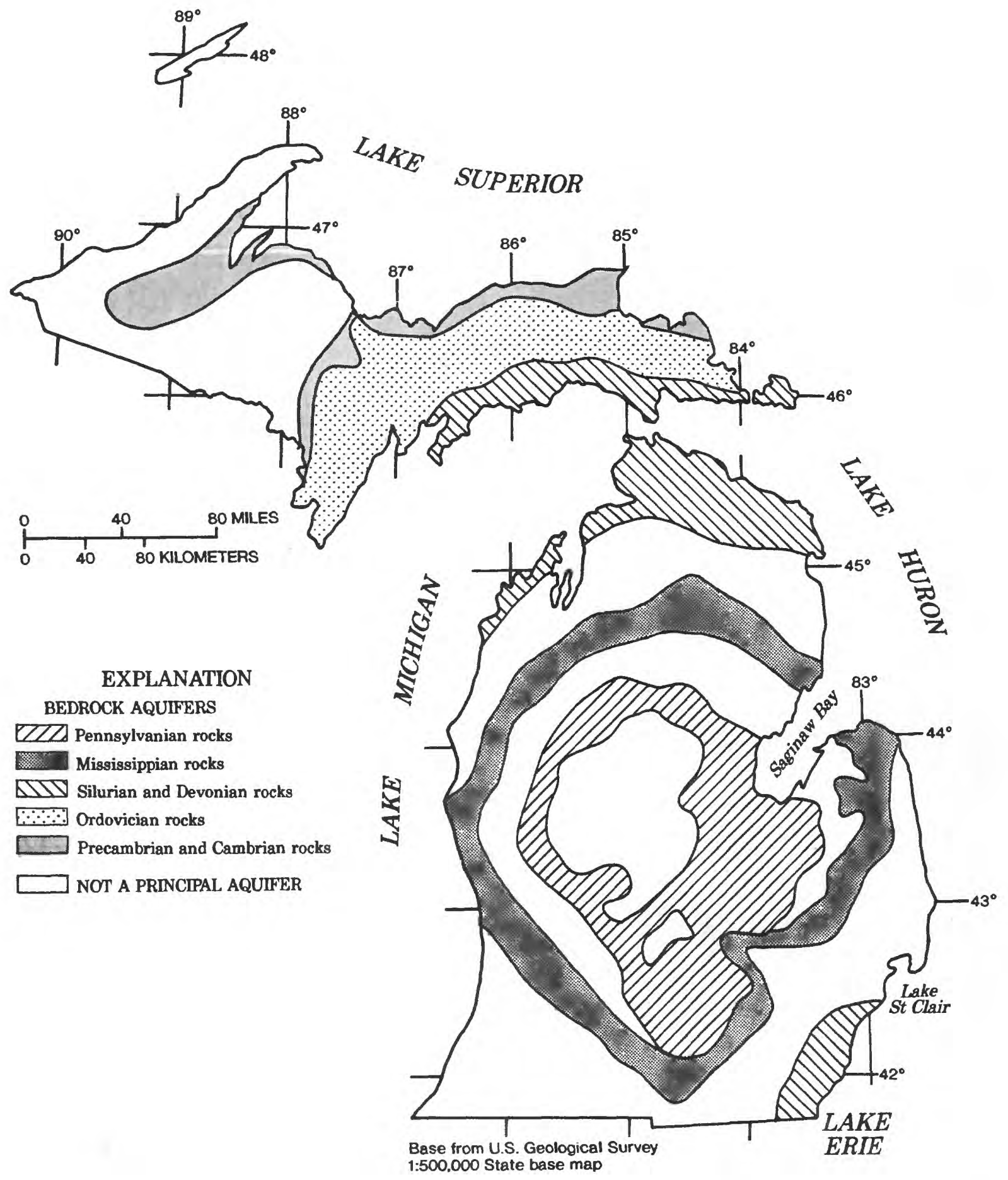

Figure 6. Areas where principal bedrock aquifers are exposed or directly underlie glacial deposits. (Modified from Grannemann and others 1985, fig. 1; see fig. 9 for areas where bedrock aquifers yield water that is too highly mineralized for most uses.) 


\begin{tabular}{|c|c|c|c|c|}
\hline ERA & SYSTEM & $\therefore$ ERIES & GROUP & STRATIGRAPHIC UNIT \\
\hline MESOZOIC & Jurassic & & & $\begin{array}{c}\text { Red beds } \\
\text { (undivided) }\end{array}$ \\
\hline \multirow{22}{*}{ 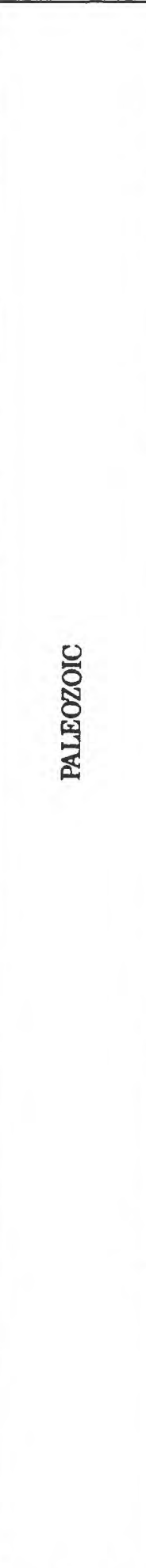 } & \multicolumn{4}{|c|}{ Unconformity } \\
\hline & \multirow[t]{2}{*}{ Pennsylvanian } & Conemaugh & & \multirow{2}{*}{$\begin{array}{c}\text { Grand River Formation } \\
\text { Saginaw Formation }\end{array}$} \\
\hline & & Pottsville & & \\
\hline & \multicolumn{4}{|c|}{ Unconformity } \\
\hline & \multirow[t]{4}{*}{ Mississippian } & Meramecian & Grand Rapids & \multirow{4}{*}{$\begin{array}{l}\text { Bayport Limestone } \\
\text { Michigan Formation } \\
\text { Marshall Sandstone } \\
\text { Coldwater Shale } \\
\end{array}$} \\
\hline & & & & \\
\hline & & Osagian & & \\
\hline & & Kinderhookian & & \\
\hline & & Lower & & Sunbury Shale \\
\hline & \multirow[t]{9}{*}{ Devonian } & & & \multirow{9}{*}{\begin{tabular}{|c} 
Berea Sandstone \\
Bedford Shale \\
$\begin{array}{c}\text { Berea Sandstone and } \\
\text { Bedford Shale } \\
\text { (undivided) }\end{array}$ \\
Ellsworth Shale \\
Antrim Shale \\
Traverse Group \\
(undivided) \\
Bell Shale \\
Dundee Limestone \\
Detroit River Group \\
(undivided) \\
Sylvania Sandstone \\
Mackinac Breccia \\
Bois Blanc Formation \\
Garden Island Formation
\end{tabular}} \\
\hline & & Chautauquan & & \\
\hline & & \multirow[t]{3}{*}{ Erian } & \multirow[t]{2}{*}{ Traverse } & \\
\hline & & & & \\
\hline & & & & \\
\hline & & \multirow[t]{3}{*}{ Ulsterian } & \multirow[t]{2}{*}{ Detroit River } & \\
\hline & & & & \\
\hline & & & & \\
\hline & & & & \\
\hline & \multicolumn{4}{|c|}{ Unconf ormity } \\
\hline & \multirow[t]{3}{*}{ Silurian } & \multirow[t]{3}{*}{ Cayugan } & Bass Islands & \multirow{2}{*}{$\begin{array}{l}\text { Bass Islands Group } \\
\text { (undivided) } \\
\text { Salina Group } \\
\text { (undivided) } \\
\text { Saint Ignace Dolomite } \\
\text { Pointe aux Chenes Shale }\end{array}$} \\
\hline & & & Salina & \\
\hline & & & & \\
\hline
\end{tabular}

Figure 7. Bedrock stratigraphy of Michigan. (From Milstein, 1987; Reed and Daniels, 1987; Chart mostly follows usage of the Michigan Department of Natural Resources Geological Survey Division.) 


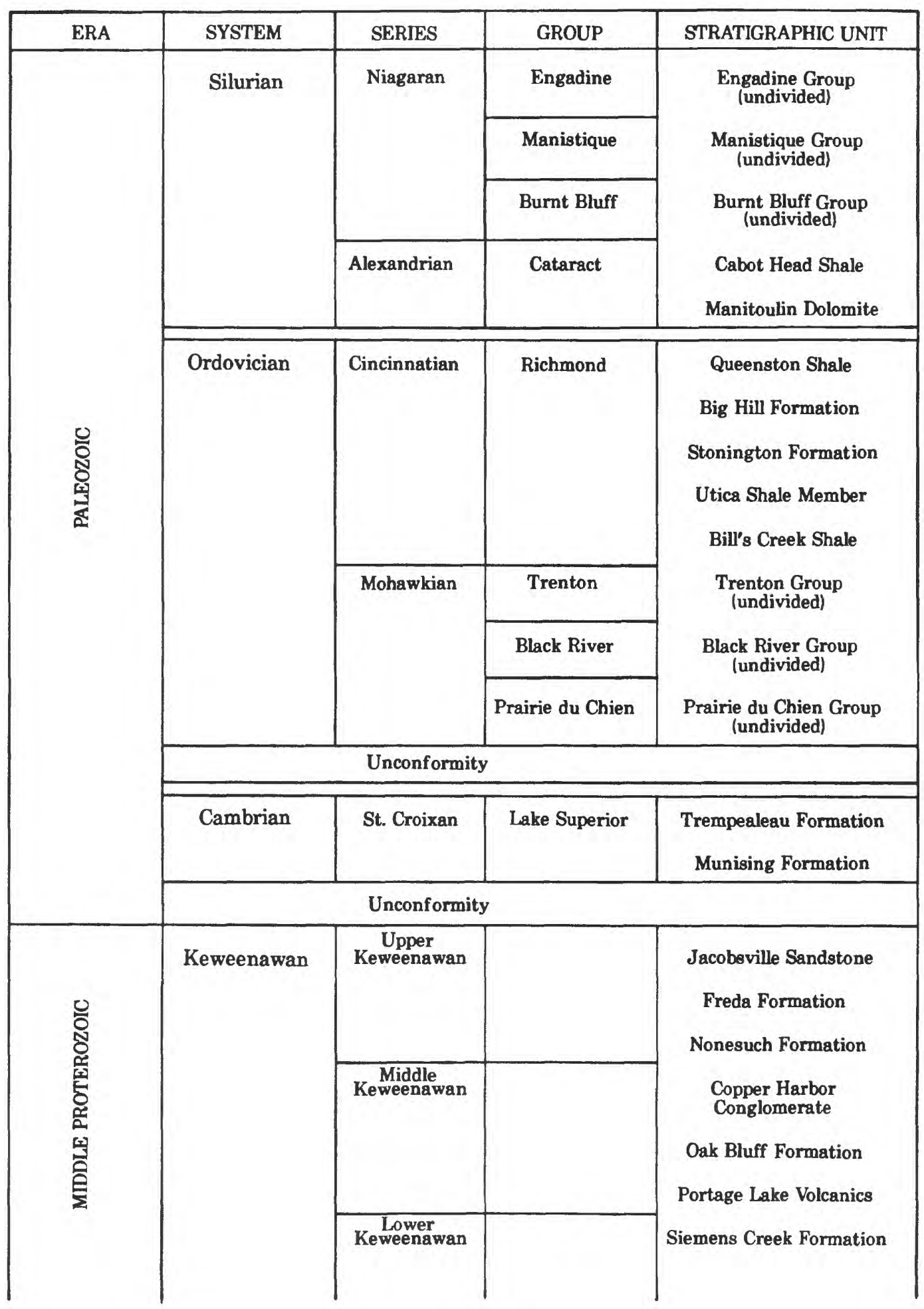

Figure 7. Bedrock stratigraphy of Michigan--Continued. 


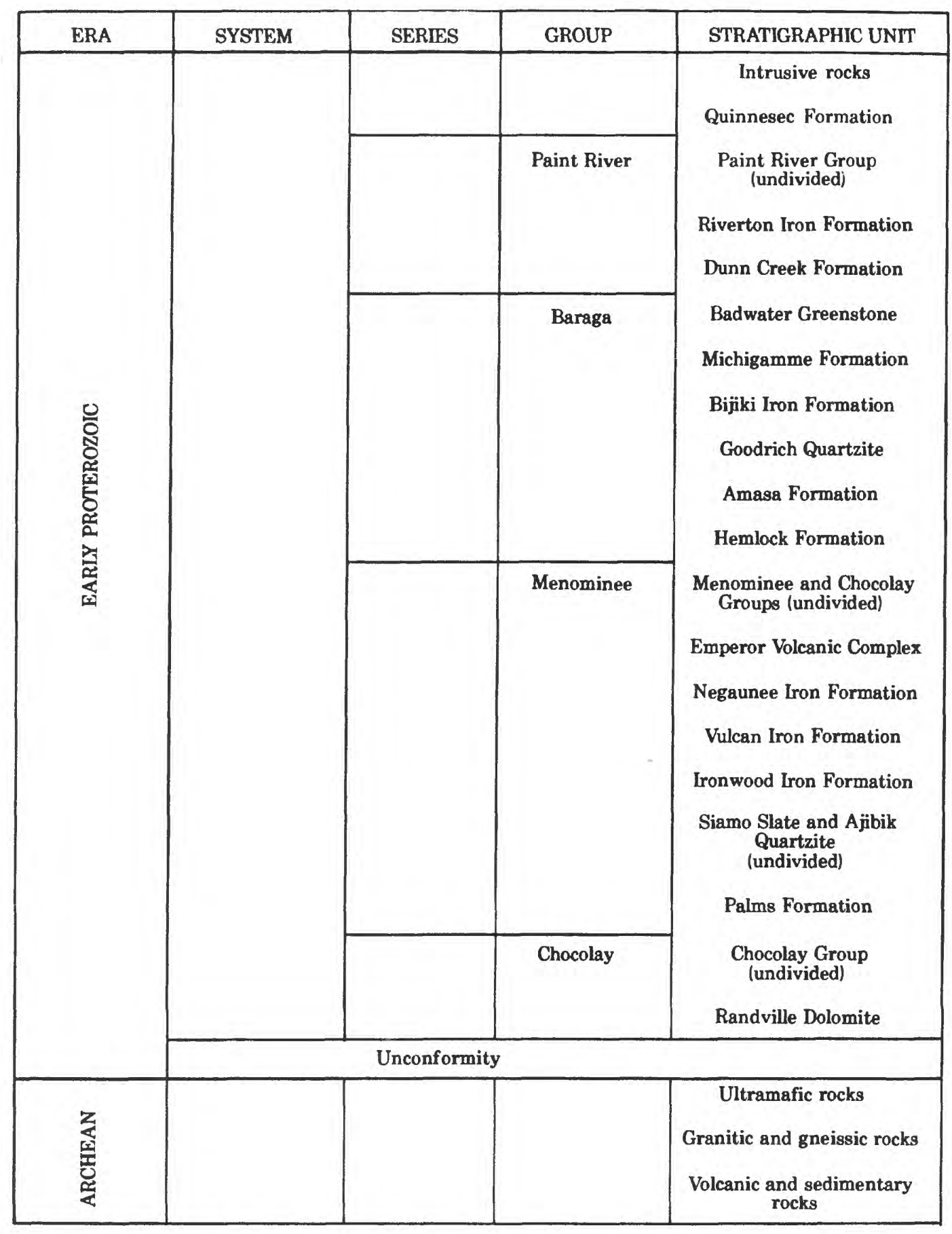

Figure 7. Bedrock stratigraphy of Michigan--Continued. 

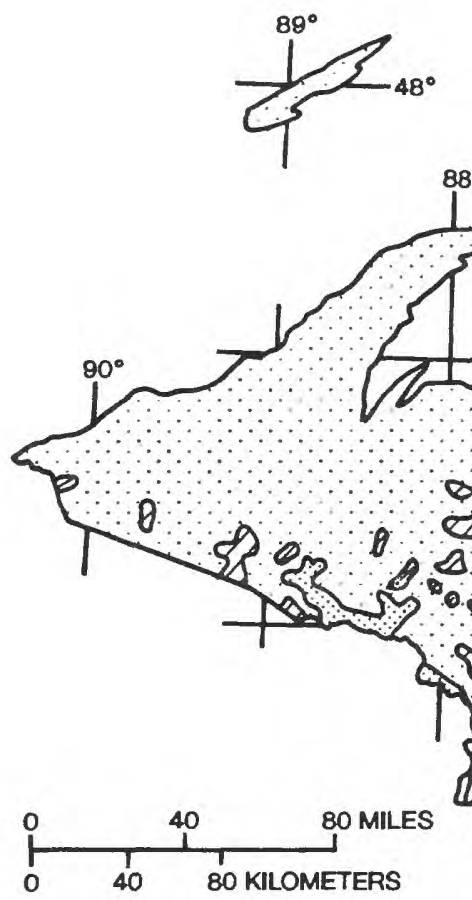

\section{$L_{A K B}$ \\ SUPERIOR}

\section{EXPLANATION}

Throughout most of these areas, wells completed in glacial deposits yield less than 10 gallons per minute. Locally, wells 6 inches or more in diameter can yield several tens of gallons per minute and in places, especially in sand and gravel deposits along streams, wells can yield more than 100 gallons per minute.

Throughout most of these areas, wells 6 inches or more in diameter and completed in glacial deposits yield from 10 to 100 gallons per minute. Locally, wells yield less than 10 gallons per minute, and in places, especially in sand and grave deposits along streams, wells can yield several bundred gallons per minute.

Throughout most of these areas, wells 8 inches or more in diameter and completed in glacial deposits yield from 100 to 500 gallons per minute. Locally, wells yield less than 100 gallons per minute, and in places, especially in sand and gravel deposits along streams, wells can yield more than 500 gallons per minute.

Throughout most of these areas, wells 10 inches or more in diameter and completed in glacial deposits yield more than 500 gallons per minute.

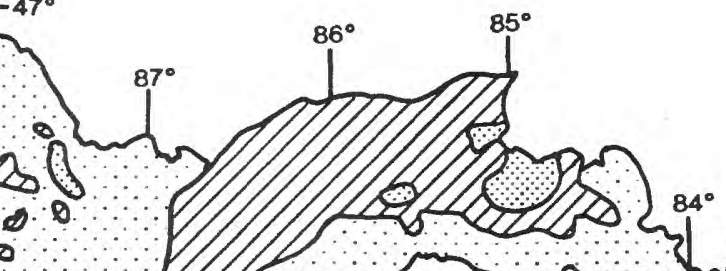
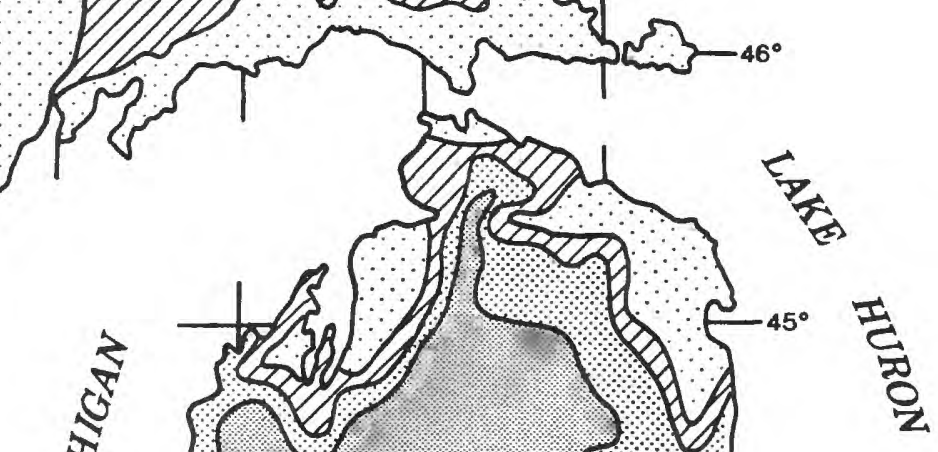

स्ष

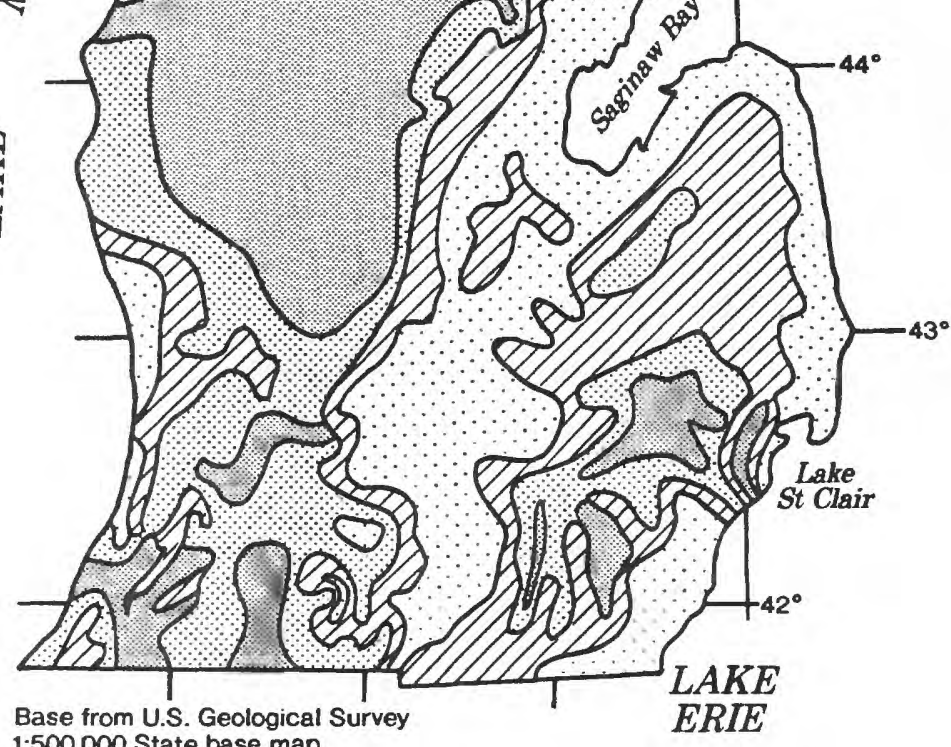

Figure 8. Potential yield of ground water from wells in glacial deposits. (Modified from Twenter, 1966b, pl.b.) 

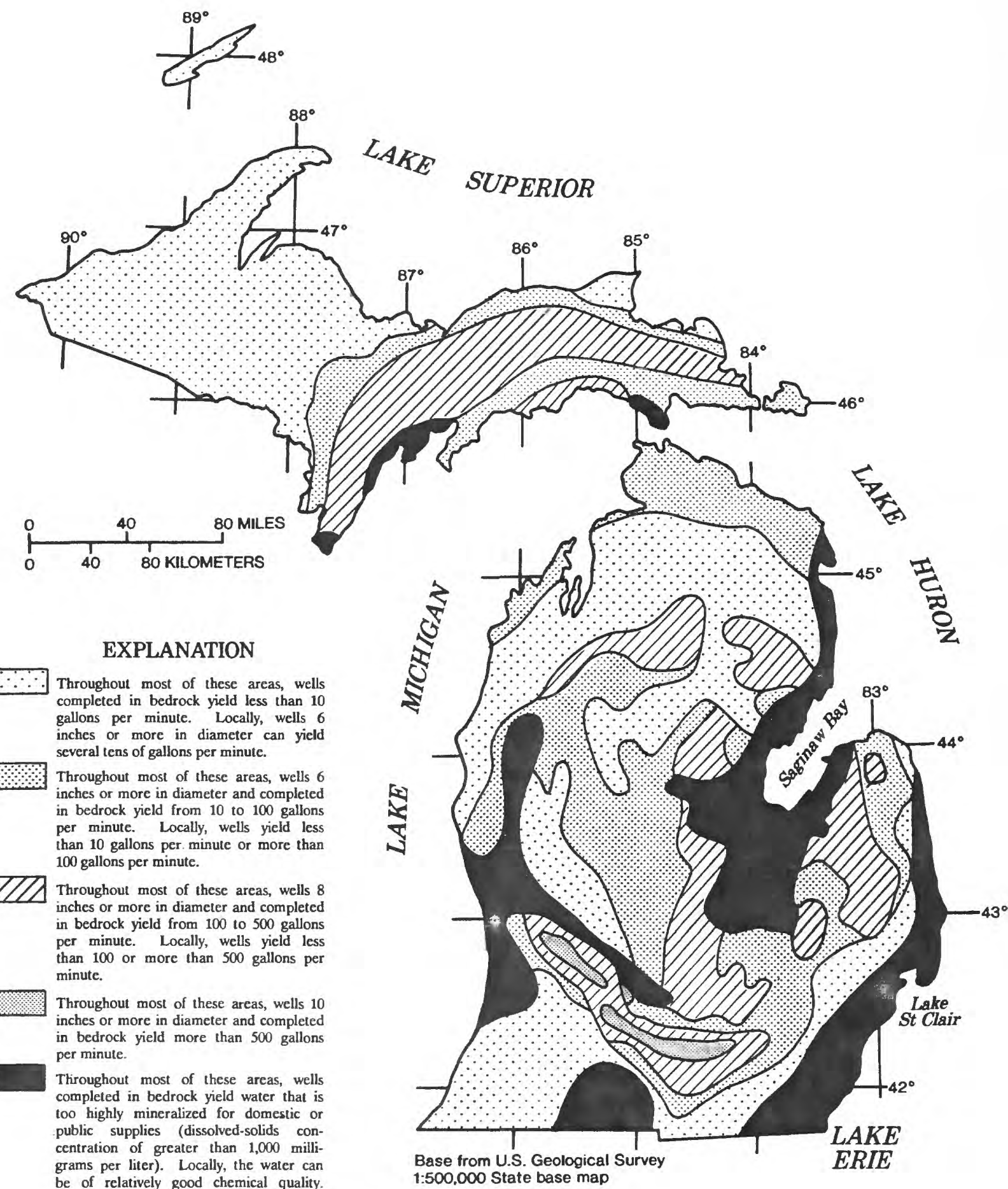
be of relatively good chemical quality. In general, the water becomes more mineralized with depth.

Figure 9. Potential yield of ground water from wells in bedrock. (Modified from Twenter, 1966a, pl.a.) 


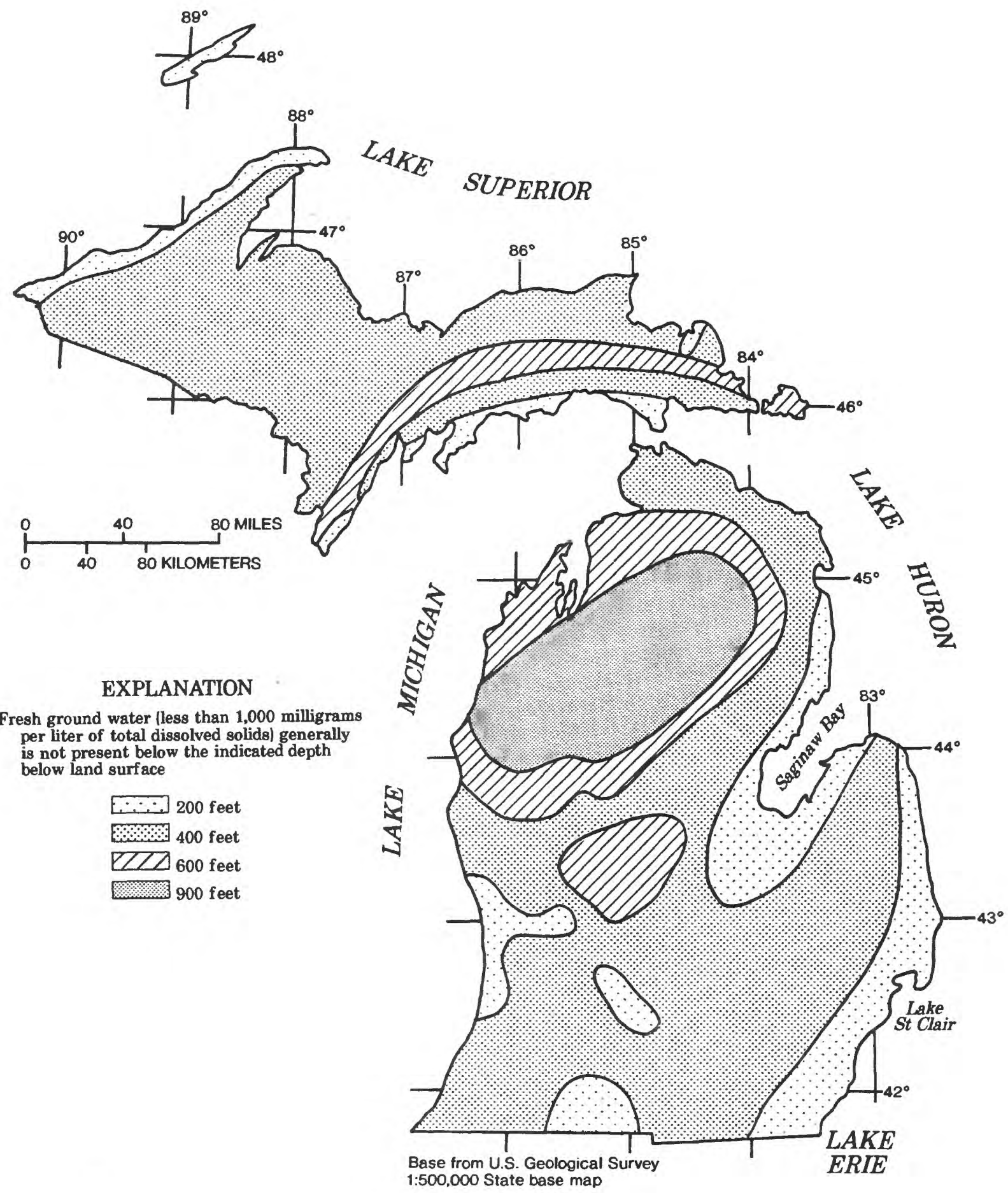

Figure 10. Approximate depth from land surface to base of fresh ground water. (Modified from Twenter, 1978, fig. 11.) 


\section{HYDROLOGIC PROVINCES}

The numbers and names of the 12 provinces are based on their location within the state ( 1 1. 1). Provinces 2, 3, 4, 8, and 9 define areas where bedrock aquifers provide most of the potable ground water. Provinces 1, 5, and 7 define areas where glacial-deposit aquifers provide most of the potable ground water. Provinces $6,10,11$, and 12 identify areas where problems with water quantity and (or) water quality have limited the use of ground water as a water supply.

The locations of streamflow and surface-water-quality sampling sites, used in the delineation of the provinces, are shown on figure 11. Streamflow characteristics of these major rivers in Michigan and their physical and chemical characteristics during low flow are listed in tables 1 and 2 (at back of report).

The locations of ground-water-quality sampling sites, used in the delineation of the provinces, are shown on figure 12. Median values of selected chemical and physical characteristics of ground water, based on water from these wells, are listed by hydrologic province and aquifer in table 3 (at back of report).

\section{Province 1--Western Upper Peninsula}

Province 1, which is approximately $6,300 \mathrm{mi}^{2}$ in area, includes most of the western Upper Peninsula (pl. 1). The province is characterized by thin glacial deposits that overlie a Precambrian igneous and metamorphic crystalline complex; the Precambrian complex consists mainly of granite, gneiss, and schist. Because the underlying Precambrian bedrock is generally incapable of providing adequate yields for a ground-water source, ground-water supplies are typically available only in low-yielding glacial deposits.

\section{Physical Setting}

Province 1 is in the Superior Upland physiographic division (fig. 1 ). The terrain ranges from near mountainous to broad level plains with numerous swamps and 1akes. In places, bedrock is exposed in rugged relief. Landsurface elevation ranges from about $600 \mathrm{ft}$ above sea level along the Lake Superior shoreline to about $1,900 \mathrm{ft}$ in Baraga and Marquette Counties.

Most of the province is heavily forested and sparsely populated. Iron Mountain (pop. 8,341), Ironwood (pop. 7,741), and Hought on (pop. 7,512) are the largest communities (U.S. Bureau of Census, 1982). 


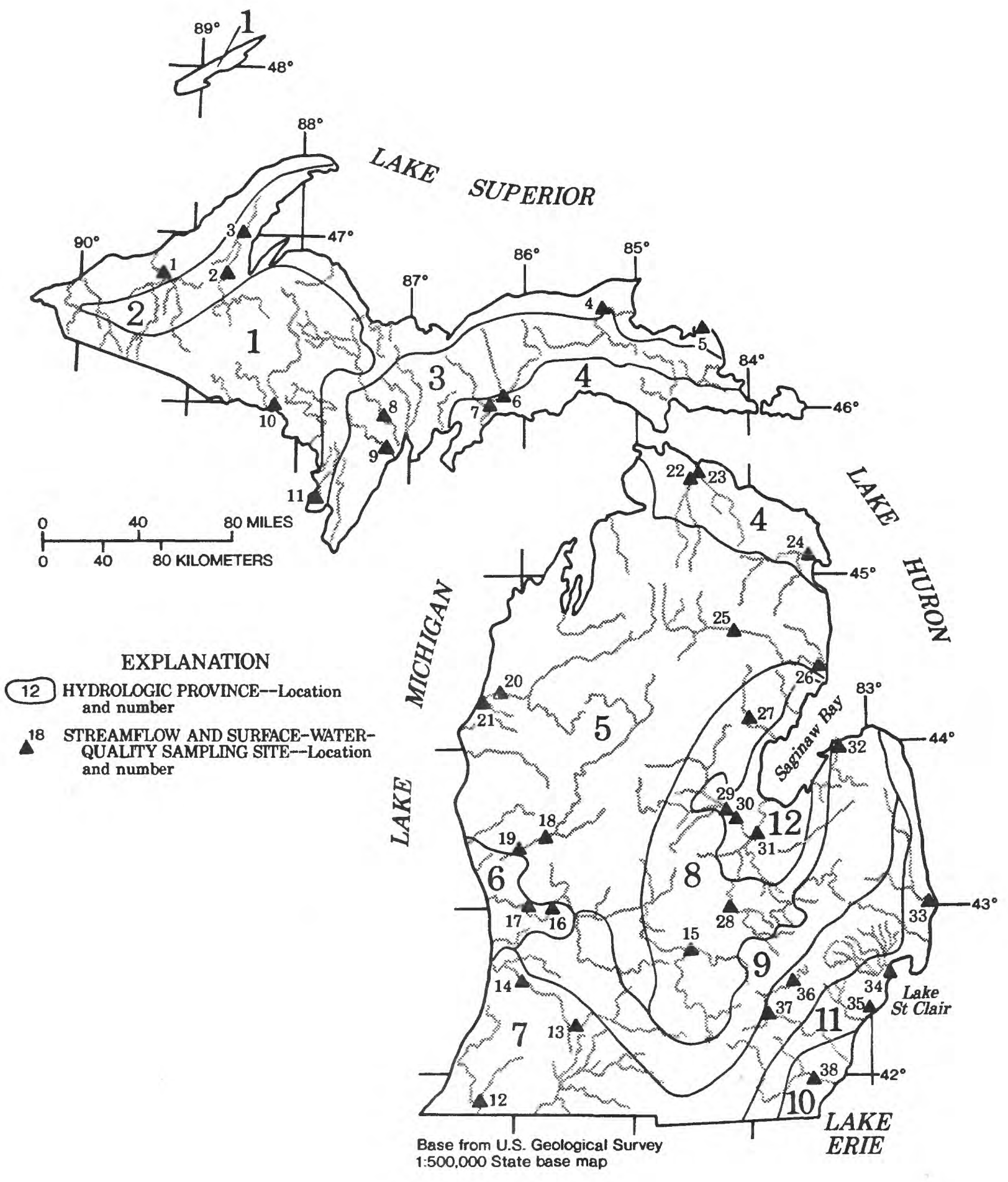

Figure 11. Locations of streamflow and surface-water-quality sampling sites. (Data are 1 isted in tables 1 and 2.) 


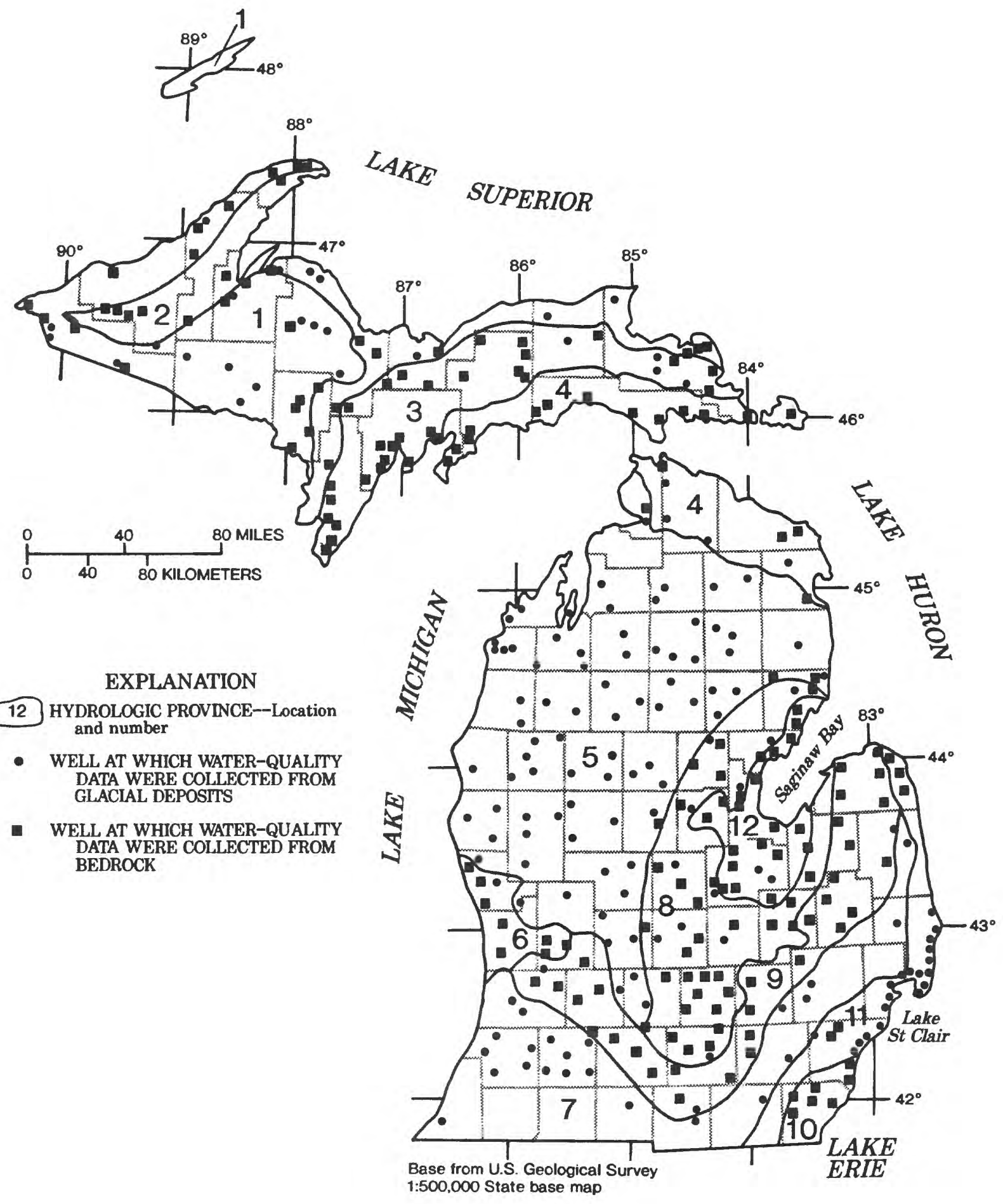

Figure 12. Locations of selected ground-water-quality sampling sites. 


\section{Surface Water}

In the northern half of the province (Subprovince $1 s^{2}$ ), surface-water drainage is to the north toward Lake Superior; in the southern half (Subprovince $1 \mathrm{~m}$ ), surface-water drainage is to the southeast toward Lake Michigan .

\section{Availability}

Six major rivers (Menominee, Ontonagon, Escanaba, Presque Isle, Black, and Montreal) and numerous minor rivers drain the province. About half of these rivers flow north to Lake Superior; the rest flow south to Lake Michigan. The Menominee River, which forms the border between Michigan and Wisconsin, is the largest river in the province (fig. 5).

Selected streamflow characteristics for the gaging station at Florence on the Memominee River (site 10, fig. 11) are listed in table 1 (at back of report). The minimum discharge for the period of record at this station was $37 \mathrm{ft}^{3} / \mathrm{s}$ on August 21, 1962; the maximum discharge was $19,500 \mathrm{ft}^{3} / \mathrm{s}$ on April 26, 1960 .

About 350 lakes in Province 1 are larger than 25 acres (Humphrys and Green, 1962). Most are in glacial moraines and outwash in the southern and eastern parts of the province. Few lakes are located along the northern boundary where Precambrian rocks outcrop or are overlain by lacustrine clay. The largest inland lake is Michigamme Reservoir (5,220 acres) in Iron County.

Surface water is typically used as a source for municipal water supply in this province (Michigan Water Resources Commission, 1968a, p. 45). To the north, communities along the shoreline withdraw water from Lake Superior. To the south and east, some rivers and a number of lakes are used for public water supply.

\section{Quality}

Analyses of surface-water-quality data collected by the U.S. Geological Survey from 1975 through 1988 indicate that waters from most rivers in the province are generally excellent when compared to drinking-water standards established by the U.S. Environmental Protection Agency (1986a, 1986b). However, the Ontonagon River is sediment-laden and turbid during spring runoff (Great Lakes Basin Commission, 1975, p. 53). Analyses of samples collected during low-flow periods indicate that most water contains low concentrations

2

Lower-case letters following the province numbers--for example, (1s) designate to which Great Lake the subprovince drains (s, Lake Superior; h, Lake Huron; m, Lake Michigan; and e, Lake Erie). 
of sulfate, chloride, and dissolved solids and that the water is soft ${ }^{3}$ (Wood, 1970 , p. 4-10). Physical and chemical characteristics of streams during low flow are listed in table 2 (at back of report).

\section{Ground Water}

Recharge to ground-water reservoirs is chiefly from percolation of rain and snowmelt, and the amount of recharge depends largely on the topography, soils, and underlying bedrock. In flat outwash areas, recharge can be $10 \mathrm{in} / \mathrm{yr}$ or more (Grannemann, 1978, p. 9); in steep bedrock areas, recharge can be less than $1 \mathrm{in} / \mathrm{yr}$ (Hendrickson and Doonan, 1966, p. 4).

Ground-water levels differ considerably throughout Province 1. Locally, some wells screened in glacial deposits and others drilled into the Precambrian bedrock flow at land surface. The maximum depth to water in the glacial deposits was $103 \mathrm{ft}$ below land surface, in Iron County in 1974 (based on water levels in 43 wells measured by the U.S. Geological Survey). The maximum depth to water in the Precambrian bedrock was $95 \mathrm{ft}$ below land surface, in Dickinson County in 1988 (based on water levels in 12 wells measured by the U.S. Geological Survey).

\section{Availability}

Ground-water resources in Province 1 are not abundant. Glacial deposits are typically less than $100 \mathrm{ft}$ thick, but can be as much as $400 \mathrm{ft}$ thick locally (Passero and others, 1981, pl. 15). Deposits include lacustrine clay along the Lake Superior shoreline and medium to coarse sandy till and outwash in the southern and eastern part of the province (Farrand and Bell, 1984, pl. 1). Throughout most of the province, wells screened in glacial deposits yield less than $10 \mathrm{gal} / \mathrm{min}$. The most favorable areas for producing ground water are areas of outwash deposits along streams. In the southern and eastern part of the province, wells 6 in. or more in diameter screened in glacial deposits yield from 10 to $100 \mathrm{gal} / \mathrm{min}$ and provide adequate water supplies for a number of small communities (Twenter, $1966 \mathrm{~b}$, pl. b). At a few locations, groundwater supplies can be obtained at shallow depths from the fractured and weathered Precambrian bedrock. Well yields in these areas can be as high as 5 $\mathrm{gal} / \mathrm{min}$, but are usually less than $1 \mathrm{gal} / \mathrm{min}$.

\section{Quality}

Water quality of glacial deposits in Province 1 is generally good; however, Cummings (1989, p. 16) noted high iron concentrations $(>1.0 \mathrm{mg} / \mathrm{L})$ in this area. Bedrock contains saline water at a depth of less than $200 \mathrm{ft}$ on the Keweenaw Peninsula.

3 U.S. Geological Survey (Durfor and Becker, 1964) has classified the hardness of water as follows: $60 \mathrm{mg} / \mathrm{L}$ or less, soft; 61 to $120 \mathrm{mg} / \mathrm{L}$, moderately hard; 121 to $180 \mathrm{mg} / \mathrm{L}$, hard; and $181 \mathrm{mg} / \mathrm{L}$ or greater, very hard. 
Province 2, which is approximately $3,765 \mathrm{mi}^{2}$ in area, extends along the northern Upper Peninsula and includes most of Michigan's Lake Superior shoreline ( $\mathrm{pl} .1$ ). The province is characterized by relatively thin glacial deposits that overlie aquifers in Precambrian and Cambrian bedrock. The glacial deposits and underlying Precambrian and Cambrian sandstones are both capable of producing limited ground-water supplies; however, the sandstones yield much less water to wells than do the adjacent aquifers in Ordovician rocks that underlies Province 3.

\section{Physical Setting}

Most of Province 2 is in the Belted Lowlands, a subdivision of the Central Lowland physiographic division (fig. 1). The terrain ranges from the hilly topography of the Precambrian outcrops in the west to the relatively flat topography of the lowlands in the east. Sandstone outcrops of the upper Keweenawan Series (Precambrian) and St. Croixan Series (Cambrian) are common throughout the province (Hamblin, 1958, p. 15). Land-surface elevation ranges from about $600 \mathrm{ft}$ above sea level along the shore of Lake Superior to about $1,400 \mathrm{ft}$ in the uplands of Ontonagon and Houghton Counties.

Province 2 is heavy forested and sparsely populated. The most highly populated areas are along the Lake Superior shoreline. Marquette (pop. 23,288), Munising (pop. 3,083), and Sault Ste. Marie (pop. 14,448) are the largest cities (U.S. Bureau of Census, 1982).

\section{Surface Water}

In the northern part of the province (Subprovince $2 \mathrm{~s}$ ), surface-water drainage is to the north and east toward Lake superior. In a narrow band south of Marquette (Subprovince $2 \mathrm{~m}$ ), surface-water drainage is to the southeast toward Lake Michigan; in a small section southeast of Sault Ste. Marie (Subprovince $2 \mathrm{~h}$ ), surface-water drainage is to the east toward the St. Marys River, which flows to Lake Huron.

\section{Availability}

Province 2 is drained by five major rivers (Ontonagon, Sturgeon, Tahquamenon, Escanaba, and Ford) and numerous minor rivers, most of which flow north into Lake Superior. The Ontonagon River is the largest river, and most of its drainage basin is within the province (fig. 5).

Selected streamflow characteristics for the gaging station at Rockland on the Ontonagon River (site 1, fig. 11) are listed in table 1 (at back of report). The minimum discharge for the period of record at this station was $192 \mathrm{ft}^{3} / \mathrm{s}$ on July 28, 1973; the maximum discharge was $42,000 \mathrm{ft}^{3} / \mathrm{s}$ on August 22, 1942 .

About 175 lakes in Province 2 are larger than 25 acres (Humphrys and Green, 1962). Most are in glacial outwash and lacustrine sands in northern Marquette, Alger, and Luce Counties. Few lakes are in the western part of the 
province (Ontonagon, Houghton, and Baraga Counties) where Precambrian bedrock outcrops or is overlain by lacustrine clay. The largest inland lake is Lake Gogebic $(14,781$ acres $)$ in Ontonagon and Gogebic Counties.

Surface-water withdrawals from Lake Superior provide the water supply for a number of nearshore communities, including the three largest cities in Province 2, Marquette, Munising, and Sault Ste. Marie.

\section{Quality}

Analyses of surface-water-quality data collected by the U.S. Geological Survey from 1975 through 1988 indicate that waters from most rivers in the province are generally good when compared to drinking-water standards established by the U.S. Environmental Protection Agency (1986a, 1986b). However, turbid water during spring runoff is common (Great Lakes Basin Commission, 1975, p. 77). Analyses of samples collected during low-flow periods indicate that most water contains low concentrations of sulfate, chloride, and dissolved solids, but the water is moderately hard (Wood, 1970, p. 4-10). Selected water-quality characteristics for the Ontonagon River are listed in table 2 (at back of report).

\section{Ground Water}

Recharge to the aquifers is primarily through the overlying glacial deposits. Recharge ranges from less than $6 \mathrm{in} / \mathrm{yr}$ in the lacustrine sand and clay in Ontonagon and Houghton Counties to greater than $15 \mathrm{in} / \mathrm{yr}$ in the outwash sand of Marquette County (Grannemann, 1984, p. 38).

Ground-water levels differ considerably throughout Province 2. Locally, some wells in glacial deposits and some wells in the Precambrian and Cambrian sandstones flow at land surface. The maximum depth to water in the glacial deposits was $146 \mathrm{ft}$ below land surface, in Marquette County in 1964 (based on water levels in 11 wells measured by the U.S. Geological Survey). The maximum depth to water in the Precambrian and Cambrian sandstones was $80 \mathrm{ft}$ below land surface, in Baraga County in 1977 (based on water levels in 10 wells measured by the U.S. Geological Survey).

\section{Availability}

Ground-water withdrawals in Province 2 are from aquifers in glacial deposits and the Precambrian and Cambrian sandstones. In general, groundwater supplies are adequate for most inland communities, but low well yield is a common problem.

Glacial deposits range in thickness from 1 to $500 \mathrm{ft}$ (Passero and others, 1981, pl. 15). Deposits west of Marquette consist of thin clay, sand, and till, and generally yield less than $10 \mathrm{gal} / \mathrm{min}$. Deposits to the south and east of Marquette consist of medium to coarse sand of increased thickness, and wells 6 in. in diameter or more typically yield from 10 to $100 \mathrm{gal} / \mathrm{min}$ (Twenter, 1966b, p1. b).

Precambrian sandstones, predominantly of the Jacobsville Sandstone, underlie the glacial deposits of the western counties of Province 2 and extend along the entire length of the southern coast of Lake Superior. Because these 
sandstones are well cemented and interbedded with siltstone and shale, they yield water primarily from fractures (Grannemann and others, 1985, p. 258). Transmissivities generally are low. Well yields range from 5 to $50 \mathrm{gal} / \mathrm{min}$ (Twenter, 1966b, pl. b). In most locations, the aquifer is confined.

Cambrian sandstones, predominantly of the Trempeleau and Munising Formations, underlie the glacial deposits in a narrow, arched band from western Menominee County to eastern Chippewa County (Reed and Daniels, 1987, pl. 1). The Cambrian sandstones are commonly used as an aquifer in the eastern counties, where well yields range from 10 to $100 \mathrm{gal} / \mathrm{min}$ (Twenter, $1966 \mathrm{a}, \mathrm{pl}$. a).

Quality

Ground water from most wells screened in glacial deposits and in bedrock in Province 2 is generally of good quality, although high concentration of iron ( $>1.0 \mathrm{mg} / \mathrm{L}$ ) is a common problem (Cummings, 1989, p. 13-16). Concentrations of dissolved solids in water from Precambrian sandstones are generally less than $1,000 \mathrm{mg} / \mathrm{L}$; however, in some areas, the Jacobsville Sandstone yields saline water that is not suitable for domestic use.

\section{Province 3--East-Central Upper Peninsula}

Province 3, which is approximately $4,690 \mathrm{mi}^{2}$ in area, includes most of the eastern half of the Upper Peninsula ( 1.1 ). The province is characterized by glacial deposits of variable thickness overlying Ordovician sandstone, limestone, and dolomite. The glacial deposits and the Ordovician bedrock form productive aquifers and yields are generally high.

\section{Physical Setting}

Province 3 is in the Belted Lowlands, a subdivision of the Central Lowlands physiographic division ( $f i g .1$ ). Most of the terrain is relatively $f 1$ at, and much of the area is covered by extensive swamps. Land-surface elevation ranges from $580 \mathrm{ft}$ above sea level along the Lake Michigan shoreline to about 1,200 ft on some upland moraines in Marquette and Luce Counties. Throughout most of the province, however, the land-surface elevation is less than $800 \mathrm{ft}$.

Most of the province is forested and sparsely populated, although small farms are operated in Delta and Menominee Counties. Most of the population is concentrated in Escanaba (pop. 14,355), Menominee (pop. 10,099), Gladstone (pop. 4,533), and other communities along the northern shore of Green Bay (U.S. Bureau of Census, 1982).

\section{Surface Water}

In the western two-thirds of the province (Subprovince $3 \mathrm{~m}$ ), surface-water drainage is southeastward toward Lake Michigan. In the eastern one-third of the province, local surface-water drainage is split between northeastward flow toward Lake Superior (Subprovince 3s) and southeastward flow toward the St. Marys River (Subprovince $3 \mathrm{~h}$ ). 
Availability

Province 3 is drained by seven major rivers (Manistique, Escanaba, Tahquamenon, Sturgeon, Whitefish, Ford, and Cedar) and a number of minor rivers. The Manistique River is the largest river, and most of its drainage basin is within the province (fig. 5).

Selected streamflow characteristics for the gaging station at Manistique on the Manistique River (site 6, fig. 11) are listed on table 1 (at back of report). The minimum discharge for the period of record at this station was $288 \mathrm{ft}^{3} / \mathrm{s}$ on October 4, 1948 ; the maximum discharge was $16,900 \mathrm{ft}^{3} / \mathrm{s}$ on May 11, 1960 .

About 200 lakes in Province 3 are larger than 25 acres (Humphrys and Green, 1962). Most are in the glacial outwash and lacustrine sands of Alger, Delta, and Schoolcraft Counties. The largest inland lake is North Manistique Lake $(1,722$ acres) in Luce County. Surface-water withdrawals from Lake Michigan are the source of water supply for Escanaba, Menominee, and Gladstone, the three largest cities.

Qual ity

Analyses of surface-water-quality data collected by the U.S. Geological Survey from 1975 through 1988 indicate that waters from most rivers in the province are generally good when compared to drinking-water standards established by the U.S. Environmental Protection Agency (1986a, 1986b). However, the Tahquamenon River is brown in color because of naturally ocurring tannin (Great Lakes Basin Commission, 1975, p. 63). Analyses of samples collected during low-flow periods indicate that most water contains low concentrations of sulfate, chloride, and dissolved solids, but the water is moderately hard (Wood, 1970, p. 4-10). Selected water-quality characteristics for the Manistique River are 1 isted in table 2 (at back of report).

\section{Ground Water}

Average recharge in Province 3 ranges from 6 to $9 \mathrm{in} / \mathrm{yr}$ (Vanlier and Deutsch, 1958a, p. 37; Vanlier, 1963a, p. 38). Recharge to the aquifers is primarily through the overlying glacial deposits; however, in the southwestern part of the province where the permeable limestone and dolomite is at or near the surface, the bedrock has large infiltration capacities (Sinclair, 1959, p. $46 ; 1960$, p. 48). Some areas in the eastern part of the province are underlain by clay-rich, lacustrine plains, which impede infiltration of precipitation (Vanlier and Deutsch, 1958a, p. 37). Infiltration is also reduced in areas where shale, shalely limestone, or dolomite is at or near the surface, such as in the Stonington Peninsula in Delta County (Sinclair, 1960, p. 48).

Ground-water levels are variable throughout Province 3. Locally, some wells screened in glacial deposits and other wells drilled into the Ordovician bedrock flow at land surface. The maximum depth to water in the glacial deposits was $28 \mathrm{ft}$ below land surface, in Chippewa County in 1964 (based on water levels in 7 wells measured by the U.S. Geological Survey). The maximum 
depth to water in the Ordovician bedrock was $81 \mathrm{ft}$ below land surface, in Delta County in 1966 (based on water levels in 14 wells measured by the U.S. Geological Survey).

Availability

Ground-water withdrawals in Province 3 are from aquifers in glacial deposits and the Ordovician rocks. Wells screened in glacial deposits are most common in the northeastern part of the province; wells completed in bedrock are most common in the southwestern part. In general, adequate ground-water supplies can be obtained throughout the province.

Although glacial deposits are absent at some locations, they can be as much as $400 \mathrm{ft}$ thick elsewhere (Passero and others, 1981, pl. 15). Deposits of medium to coarse sand are thickest in the northeastern part of the province. Throughout most of Chippewa and Luce Counties, wells 6 in. or more in diameter that are screened in glacial deposits yield from 10 to 100 $\mathrm{gal} / \mathrm{min}$; in some areas, wells 8 in. or more in diameter yield as much as $500 \mathrm{gal} / \mathrm{min}$. Glacial deposits thin to the southwest, and most wells screened in glacial deposits in Delta and Menominee Counties yield less than $10 \mathrm{gal} / \mathrm{min}$ (Twenter, 1966b, pl. b).

The Ordovician rocks consist of fine- to coarse-grained sandstone in the lower aquifers and limestone or dolomite in the upper aquifers (Grannemann and others, 1985, p. 258). The transmissivity of the aquifers depends primarily on 1 ithology and thickness. The aquifers generally are confined. Wells 6 in. or larger in diameter that have been drilled into the aquifers in Ordovician rocks typically yield from 50 to $500 \mathrm{gal} / \mathrm{min}$ (Twenter, 1966a, pl. a).

\section{Quality}

Water quality of glacial deposits in Province 3 is generally excellent. Most water is soft and contains low dissolved-solids concentrations, but high concentrations of iron ( $>1.0 \mathrm{mg} / \mathrm{L}$ ) are common. Water quality in the Ordovician bedrock is generally good, although the water is sometimes hard to very hard and contains high concentrations of iron ( $>1.0 \mathrm{mg} / \mathrm{L}$ ) (Cummings, 1989, p. 13-16). In some locations, ground water from the Ordovician bedrock contains high concentrations of sodium (50-100 mg/L) and chloride $(200-400$ $\mathrm{mg} / \mathrm{L}$ ). In these areas, wells drilled into the deeper Precambrian and Cambrian sandstones often yield water of better quality (Sinclair, 1959, p. 56). In the southern part of Menominee County, glacial deposits are thin, and bedrock aquifers yield "sulfur water" (Vanlier, 1963b, p. 7).

\section{Province 4--Northern Lower and Southeastern Upper Peninsula}

Province 4, which is approximately $3,930 \mathrm{mi}^{2}$ in area, is split between the southeastern corner of the Upper Peninsula and the northern tip of the Lower Peninsula along the shorelines of Lake Michigan and Lake Huron (pl. 1). The province is characterized by relatively thin glacial-lacustrine sand that overlies Silurian and Devonian limestone and dolomite. The aquifers in Silurian and Devonian rocks are the primary source of most ground-water supplies. Glacial deposits, where sufficiently thick, are sometimes used for domestic supply. Wells drilled into aquifers in the Silurian and Devonian 
rocks yield less than wells drilled into aquifers in the Ordovician rocks of Province 3, to the north, or wells screened in the glacial deposits of Province 5 , to the south.

\section{Physical Setting}

Province 4 is in the Northern Uplands, a subdivision of the Central Lowlands physiograpic division (fig. 1). The topography is flat to rolling, and it includes extensive swamps, wetlands, and numerous lakes. Land-surface elevation ranges from about $580 \mathrm{ft}$ above sea level along the shoreline of Lakes Michigan and Huron to about $950 \mathrm{ft}$ on the upland moraines of Mackinac County. Throughout most of the province, however, the elevation of the land surface generally is less than $800 \mathrm{ft}$. Outcrops are common along the coastline of Lakes Michigan and Huron; the most prominent outcrop is the "Niagaran Escarpment" of Mackinac and Chippewa Counties. This escarpment, formed by resistant 1 imestone and dolomite (Vanlier and Deutsch, 1958a, p. 16; $1958 \mathrm{~b}, \mathrm{p} .16)$, trends in a broad east-west arc across the southern Upper Peninsula.

Province 4 is heavily forested and sparsely populated; most of the population is concentrated near large inland lakes or along the shoreline of Lakes Michigan and Huron. The five largest cities are Alpena (pop. 12,214), Cheboygan (pop. 5,106), Manistique (pop. 3,962), Rogers City (pop. 3,923), and St. Ignace (pop. 2,632) (U.S. Bureau of Census, 1982).

\section{Surface Water}

Surface-water drainage in the western half of the province is split between northward flow toward Lake Superior (Subprovince $4 \mathrm{~s}$ ) and southward flow toward Lake Michigan (Subprovince $4 \mathrm{~m}$ ). In the eastern half of the province (Subprovince $4 \mathrm{~h}$ ), surface-water drainage is toward Lake Huron.

Availabilty

Five major rivers (Cheboygan, Thunder Bay, Manistique, Munuscong, and Pine) and numerous minor rivers drain the province. The Cheboygan River, in the Lower Peninsula, is the largest river in Province 4 (fig. 5). Tributaries of the Cheboygan include the Maple, Pigeon, Sturgeon, and Black Rivers.

Selected streamflow characteristics for the gaging station at Cheboygan on the Cheboygan River (site 22, fig. 11) are listed in table l (at back of report). The minimum discharge for the period of record at this station was $90 \mathrm{ft}^{3} / \mathrm{s}$ on March 29, 1958; the maximum discharge was $1,970 \mathrm{ft}^{3} / \mathrm{s}$ on May 22, 1979.

About 190 lakes in Province 4 are larger than 25 acres, and 9 are larger than 3,000 acres (Humphrys and Green, 1962). Mullett Lake (17,080 acres) is the largest lake in the Lower Peninsula part of the province; Manistique Lake $(10,130$ acres $)$ is the largest lake in the Upper Peninsula part of the province. Although surface water is an abundant resource, only the cities of Alpena and St. Ignace use it for public supply; both cities withdraw water from Lake Huron. 


\section{Quality}

Analyses of surface-water-quality data collected by the U.S. Geological Survey from 1975 through 1988 indicate that waters from most rivers in the province are generally good when compared to drinking-water standards established by the U.S. Environmental Protection Agency (1986a, 1986b). However, there is some degradation of water quality near the mouths of the Cheboygan and Manistique Rivers. Analyses of water at low-flow periods showed that most rivers in the province have low concentrations of sulfate, chloride, and dissolved solids, but the water is hard to very hard (Wood, 1970, p. 410). Selected water-quality characteristics for the Cheboygan River are listed in table 2 (at back of report).

\section{Ground Water}

Recharge is primarily through overlying glacial deposits. Average recharge for Province 4 ranges from about $4 \mathrm{in} / \mathrm{yr}$ in lacustrine clay areas of northeastern Mackinac County to $7 \mathrm{in} / \mathrm{yr}$ in coarse-grained sands of Emmet, Cheboygan, and Presque Isle Counties. In some areas in the Upper Peninsula part of the province, permeable limestone and dolomite at or near land surface have large infiltration capacities (Vanlier and Deutsch, 1958a, p. 27; 1958b, p. 26).

Ground-water levels differ throughout Province 4. Locally, some wells drilled into aquifers in the Silurian and Devonian rocks flow at land surface. The maximum depth to water in the glacial deposits was $60 \mathrm{ft}$ below 1 and surface, in Cheboygan County in 1982 (based on water levels in 6 wells measured by the U.S. Geological Survey). The maximum depth to water in the Silurian and Devonian bedrock was $32 \mathrm{ft}$ below land surface, in Mackinac County in 1963 (based on water levels in 15 wells measured by the U.S. Geological Survey).

\section{Availability}

Ground-water yields in Province 4 are adequate for domestic and small municipal water supplies in most places. Principal aquifers of the province are limestone and dolomite of the Niagaran Series of Middle Silurian age; limestone, dolomite, and breccia of Late Silurian and Middle Devonian age; and, in some places, sand and gravel deposits of Pleistocene age (Vanlier and Deutsch, 1958b, p. 22).

Glacial deposits, where present, consist mostly of low-lying lacustrine plains that range from less than 1 to $200 \mathrm{ft}$ in thickness (Passero and others, 1981, pl. 15). Developing ground-water supplies in glacial lacustrine deposits is difficult; clay, silt, and fine sand are predominant in these deposits and usually limit well yields to less than $10 \mathrm{gal} / \mathrm{min}$ (Twenter, $1966 \mathrm{~b}, \mathrm{pl}$. b). Yields from wells screened in glacial deposits are greater in Emmet, Cheboygan, and Presque Isle Counties than elsewhere in the province. In these counties, glacial deposits are thicker, and the sand is coarser (Michigan Water Resources Commission, 1968b, p. 6). 
Aquifers in Silurian and Devonian rocks provide most of the ground-water supply for Province 4. Transmissivities of these aquifers depend to a large extent on the number and interconnection of fractures and solution channels (Grannemann and others, 1985, p. 258). Aquifers in Silurian and Devonian bedrock generally are confined. Wells 6 in. or more in diameter drilled into these aquifers will typically yield from 10 to $100 \mathrm{gal} / \mathrm{min}$ (Twenter, 1966a, pl. a).

\section{Quality}

The quality of ground water in Province 4 varies with the 1 ithology and depth of the aquifers. Data from Cummings (1989, p. 13-16) indicate that water from aqifers in glacial deposits and Silurian and Devonian rocks is typically hard to very hard and contains high concentrations of iron $(>1.0$ $\mathrm{mg} / \mathrm{L}$ ). In some places, bedrock aquifers containing good-quality water are covered or underlain by aquifers containing water of objectionable chemical quality. Problems with salinity and high concentrations of sulfate (100-300 $\mathrm{mg} / \mathrm{L}$ ) are common in the Garden Peninsula of Delta County and the St. Ignace Peninsula of Mackinac County (Sinclair, 1959, p. 18).

\section{Province 5--North-Central Lower Peninsula}

Province 5, the 1 argest province, is an area of approximately $16,000 \mathrm{mi}^{2}$ in the north-central Lower Peninsula ( $p l .1)$. The province is characterized by thick, coarse-grained, sandy outwash and glaciofluvial deposits that overlie sedimentary bedrock of Devonian, Mississippian, Pennsylvanian, and Jurassic age. Many of the bedrock formations are a productive source of fresh water, but they are seldom used because of depth. Glacial deposits provide most of the ground-water supply, but these deposits are thinner and less permeable at the north, south, and eastern boundaries than they are in the rest of the province.

\section{Physical Setting}

Most of Province 5 is in the Northern Lowlands, a subdivision of the Central Lowlands physiographic division ( $f$ ig. 1). The topography ranges from flat lacustrine beaches and plains near Lakes Michigan and Huron to rough, rolling moraines in the central part of the province. Bedrock outcrops are present only in Emmet, Charlevoix, and Antrim Counties. Land-surface elevation ranges from $580 \mathrm{ft}$ above sea level along the shoreline of Lakes Michigan and Huron to more than $1,700 \mathrm{ft}$ in Osceola County.

Most of Province 5 is forested. Population is sparse in the northeast and moderately dense in the southwest. The five largest cities are Traverse City (pop. 15,516), Big Rapids (pop. 14,361), Cadillac (pop. 10,199), Ludington (pop. 8,937), and Manistee (pop. 7,566) (U.S. Bureau of Census, 1982 ).

\section{Surface Water}

Surface-water drainage in the western two-thirds of the province (Subprovince $5 \mathrm{~m}$ ) is toward Lake Michigan, and most of the area drains to the 
southwest; however, some basins in the Grand Traverse Bay area drain to the northwest. Surface-water drainage in the eastern one-third of the province (Subprovince $5 \mathrm{~h}$ ) is southeastward toward Lake Huron.

Availability

Eight major rivers (Muskegon, Au Sable, Grand, Manistee, Pere Marquette, White, Boardman, and Jordan) and numerous minor rivers drain Province 5. Selected streamflow characteristics for three of the largest rivers (Muskegon, Au Sable, and Manistee) are listed in table 1 (at back of report).

The Muskegon River is the largest river in Province 5. The minimum discharge for the period of record at the streamflow-gaging station at Newaygo on the Muskegon River (site 18, fig. 11) was $52 \mathrm{ft} / \mathrm{s}$ on October 2, 1965; the maximum discharge was $23,200 \mathrm{ft}^{3} / \mathrm{s}$ on September 12, 1986 .

About 800 lakes in Province 5 are larger than 25 acres (Humphrys and Green, 1962). Although lakes are distributed throughout the province, most of the largest lakes are in the northern half. Houghton Lake $(19,600$ acres $)$, the largest inland lake in the province as well as in the State, is in Roscommon County.

Surface-water withdrawals provide the water supply for three of the four largest cities. Traverse City and Ludington withdraw water from Lake Michigan; Big Rapids withdraws water from the Muskegon River (Bede11, 1982).

Quality

Analyses of surface-water-quality data collected by the U.S. Geological Survey from 1975 through 1988 indicate that waters from most rivers in the province are generally good when compared to drinking-water standards established by the U.S. Environmental Protection Agency (1986a, 1986b). However, water quality is somewhat degraded in the lower reaches of the larger rivers. Analyses of samples collected during low-flow periods indicate that water from most rivers in the northern part of the province contain low concentrations of sulfate, chloride, and dissolved solids, but concentrations are higher in water from rivers to the south (Wood, 1970, p. 4-10). Selected water-quality characteristics for the three largest rivers in the province are listed in table 2 (at back of report).

\section{Ground Water}

Conditions for recharge are favorable in most of Province 5, and recharge rates average from 9 to $15 \mathrm{in} / \mathrm{yr}$ (Stark and others, 1983, p. 19). Most rivers maintain relatively stable flow and cool temperatures because of a large contribution of ground water, which, in turn, results from substantial recharge (Hendrickson and Doonan, 1970; 1971a; 1971b;1974).

Ground-water levels differ considerably throughout Province 5. Locally, some wells screened in glacial deposits flow at land surface. The maximum depth to water in the glacial deposits was $88 \mathrm{ft}$ below land surface, in Ionia County in 1964 (based on water levels in 42 wells measured by the U.S. Geological Survey). Most bedrock is too deep (greater than $400 \mathrm{ft}$ ) to be used as a water supply, and insufficient water-level data are available for 
evaluation. However, in Iosco County where the drift is thin, water levels measured by the U.S. Geological Survey in two wells in Mississippian bedrock ranged from 7 to $40 \mathrm{ft}$ below land surface.

\section{Availability}

Ground-water resources in Province 5 are generally abundant although mostly undeveloped (Michigan Water Resources Commission, 1968b, p. 45). Most domestic and municipal ground-water supplies are from sandy glacial deposits, which are more than $1,000 \mathrm{ft}$ thick in some areas (Passero and others, 1981, p1. 15). Throughout most of the area, wells 10 in. or more in diameter that are screened in glacial deposits will yield greater than $500 \mathrm{gal} / \mathrm{min}$ (Twenter, $1966 \mathrm{~b}, \mathrm{pl}$. b); however, the predominance of clay, silt, and fine sand in the glacial-lake plains along the Lake Michigan shoreline and Grand Traverse Bay make these difficult areas in which to develop ground-water supplies.

The availability of ground water in bedrock is determined largely by lithology and depth. In general, sandstone is the most productive and shale is the least productive. Throughout much of Province 5, bedrock can yield fresh ground water, but it is seldom tapped as a water supply because it is commonly 400 to $1,000 \mathrm{ft}$ below land surface and because ground water is readily available in the overlying glacial deposits (Michigan Water Resources Commission, $1968 \mathrm{~b}$, p. 45). In the northern part of the province, the Antrim and Coldwater Shales are considered to be nonyielding. In the center of the province, the Marshall Sandstone is considered to be a productive aquifer; its yields range from 100 to $500 \mathrm{gal} / \mathrm{min}$. In the southern part of the province, the Grand River and Saginaw Formations are potential sources of moderate to large supplies of water (10 to $100 \mathrm{gal} / \mathrm{min}$ ); however, yields to wells drilled into these formations depend primarily upon the amount of sandstone present (Twenter, 1966a, p1. a).

\section{Quality}

Ground-water quality in Province 5 is generally good; however, in a few areas, the water is hard and contains high concentrations of iron ( $>1.0 \mathrm{mg} / \mathrm{L})$ (Cummings, 1989, p. 13-16). By far, the principal source of ground-water supplies is glacial deposits. Ground water of good quality can be obtained from the Marshall Sandstone (Mississippian) in Ogemaw and Iosco Counties where overlying glacial deposits are thin.

\section{Province 6--West-Central Lower Peninsula}

Province 6 is in the west-central part of the Lower Peninsula; it includes an area of approximately $930 \mathrm{mi}^{2}$ (pl. 1). The province is characterized by low yielding, lacustrine deposits of varible thickness that overlie Mississippian bedrock containing highly mineralized water. Limited amounts of fresh ground-water supplies are available only from the glacial deposits; therefore, the larger commities rely on surface water from Lake Michigan for their water-supply needs.

\section{Physical Setting}

Province 6 is at the center of the Michigan Lowlands, a subdivision of the Central Lowland physiographic division (fig. 1). The eastern half of the 
province is covered by relatively flat, featureless lacustrine sand; the western half is covered by low moraines, till plains, and outwash channels. Land-surface elevation ranges from $580 \mathrm{ft}$ above sea level along the Lake Michigan shoreline to about $800 \mathrm{ft}$ at the top of a few sand dunes and inland moraines. Most of the province, however, is at an elevation of less than 700 ft. Surface-water drainage in the province (Subprovince $6 \mathrm{~m}$ ) is to the west toward Lake Michigan.

The province is moderately to heavily populated, and land use is fairly evenly divided among forest, farming, and urban areas. Grand Rapids (pop. 181,843), Muskegon (pop. 40,823), Holl and (pop. 26,281), and Grand Haven (pop. $11,763)$ are the largest cities in the province (U.S. Bureau of Census, 1982).

\section{Surface Water}

\section{Availability}

Four major rivers (Grand, Muskegon, White, and Macatawa) and a few small streams drain Province 6; all flow west toward Lake Michigan. Selected streamflow characteristics for the gaging station at Grand Rapids on the Grand River (site 16, fig. 11) are listed in table 1 (at back of report). The minimum discharge for the period of record at this gage was $381 \mathrm{ft}^{3} / \mathrm{s}$ on August 9, 1936; the maximum discharge was $54,000 \mathrm{ft}^{3} / \mathrm{s}$ on March 28, 1904 .

About 30 lakes in Province 6 are larger than 25 acres (Humphrys and Green, 1962). Most are in low-lying lacustrine sand near the shoreline of Lake Michigan. The largest lake is Muskegon Lake (4,150 acres), in Muskegon County.

The cities of Grand Rapids, Muskegon, Holland, and Grand Haven cannot obtain sufficient fresh ground water and, instead, obtain surface water from Lake Michigan for their water-supply needs. Most small neighboring communities have connected to these large central-supply systems. Grand Rapids withdraws some of its water supply from the Grand River.

\section{Quality}

Analyses of surface-water-quality data collected by the U.S. Geological Survey from 1975 through 1988 indicate that waters from most rivers in the province are considered only fair when compared to drinking-water standards established by the U.S. Environmental Protection Agency (1986a, 1986b). All major rivers have sections of degraded quality near their mouths. Analyses of samples collected during low-flow periods indicate that water from rivers in the province contains elevated concentrations of sulfate ( $40-80 \mathrm{mg} / \mathrm{L})$, chloride $(20-50 \mathrm{mg} / \mathrm{L})$, and dissolved solids $(300-400 \mathrm{mg} / \mathrm{L})$; the water is also hard (Wood, 1970, p. 4-10). Selected water-quality characteristics for the Grand River are 1 isted in table 2 (at back of report).

\section{Ground Water}

Recharge to the aquifers is through the overlying glacial deposits. Recharge in Province 6 ranges from $7 \mathrm{in} / \mathrm{yr}$ in low-lying lake plains (McDonald and Fleck, 1978, p. 7) to about $10 \mathrm{in} / \mathrm{yr}$ in sand-covered uplands (McDonald, 1980 , p. 8). 
Ground-water levels differ considerably throughout Province 6. Locally, some wells screened in glacial deposits flow at land surface. The maximum depth to water in the glacial deposits was $57 \mathrm{ft}$ below land surface, in Kent County in 1964 (based on water levels in three wells measured by the U.S. Geological Survey). The maximum depth to water in the Pennsylvanian bedrock was $103 \mathrm{ft}$ below 1 and surface, in Kent County in 1967 (based on water levels in eight wells measured by the U.S. Geological Survey).

Availability

Ground-water resources in Province 6 are 1 imited (Michigan Water Resources Commission, 1968c, p. 45). Glacial deposits range from 50 to $250 \mathrm{ft}$ in thickness (Passero and others, 1981, pl. 15), but most deposits contain high percentages of clay and silt and therefore are of low permeability. Well yields are usually less than $25 \mathrm{gal} / \mathrm{min}$ (McDonald and Fleck, 1978, p. 7 ). Some small communities and most rural residents can obtain limited ground water supplies from glacial deposits; however, water levels decline in response to heavy pumping, and dissolved-solids concentrations of the water increases with time (Deutsch and others, 1959, p. 53).

Glacial deposits are underlain by Mississippian sandstone and siltstone of the Michigan Formations and Marshall Sandstone in the northern half of Province 6 and by the Coldwater Shale to the south. In other parts of the State, the Marshall Sandstone is typically a productive source of potable water; however, in this province, it is of low permeability and of ten contains highly mineralized water. In the southern part of the province, the Coldwater Shale is extremely low-yielding and contains highly mineralized water.

Quality

Natural ground-water quality in glacial deposits and Mississippian bedrock in Province 6 is generally poor (Michigan Water Resources Commission, $1968 \mathrm{c}$, p. 46). The water is commonly hard to very hard and usually contains high concentrations of iron $(>1.0 \mathrm{mg} / \mathrm{L})$. The water from wells drilled into the Mississippian bedrock of ten contains high concentrations of sodium (300$800 \mathrm{mg} / \mathrm{L})$, chloride $(500-1,500 \mathrm{mg} / \mathrm{L})$, sulfate $(100-500 \mathrm{mg} / \mathrm{L})$, and dissolved solids $(1,000-4,000 \mathrm{mg} / \mathrm{L})$. The freshwater/saline-water interface in some places is less than $100 \mathrm{ft}$ below land surface (Westjohn, 1988, p. 128).

In the Grand Rapids area, where glacial deposits are thin, ground water from the Marshall Sandstone contains objectionable quantities of sulfate ( 200 to $600 \mathrm{mg} / \mathrm{L}$ ), and the water is hard because of the proximity of the gypsumbearing Michigan Formation (Michigan Water Resources Commission, 1968c, p. 46).

\section{Province 7--Southern Lower Peninsula}

Province 7 includes approximately $6,860 \mathrm{mi}^{2}$ of the Lower Peninsula and covers most of the area adjacent to the southern border of the State ( $p 1.1)$. The province is characterized by generally thick, coarse-grained outwash and glaciofluvial deposits that overlie extremely low-yielding Mississippian shale containing highly mineralized water. Abundant ground-water supplies are available, but only from the overlying glacial deposits. 


\section{Physical Setting}

The western half of Province 7 is in the Michigan Lowlands, and the eastern half is in the Thumb Uplands; both areas are subdivisions of the Central Lowland Physiographic division (fig. 1). The topography is rolling, ranging from upland moraines to low-lying till plains and glacial outwash. Land-surface elevation ranges from $580 \mathrm{ft}$ above sea level along the Lake Michigan shoreline to about 1,200 ft at the top of some of the largest moraines.

The province is moderately populated. Much of the land is farmed, and urban areas are evenly distributed. The largest cities are Ann Arbor (pop. 107,966), Kalamazoo (pop. 79,722), Pontiac (pop. 76,715), Adrian (pop. $21,186)$, Benton Harbor (pop. 14,707), and Niles (pop. 13,115).

\section{Surface Water}

Surface-water drainage in the western half of the province (Subprovince $7 \mathrm{~m}$ ) is westward toward Lake Michigan. Surface-water drainage in the eastern half (Subprovince 7e) is southeastward toward the St. Clair-Detroit River system and Lake Erie.

\section{Availability}

Parts of eight major rivers (St. Joseph, Kalamazoo, Paw Paw, Raisin, Huron, Clinton, Belle, and Black) and several minor rivers drain Province 7. The St. Joseph River is the largest river, and most of its drainage basin is within the province.

Selected streamflow characteristics for the gaging station at Niles on the St. Joseph River (site 12, fig. 11) are listed in table 1 (at back of report). The minimum discharge for the period of record at this station was $420 \mathrm{ft}^{3} / \mathrm{s}$ on August 30,1931 ; the maximum discharge was $20,200 \mathrm{ft}^{3} / \mathrm{s}$ on April 5, 1950.

About 500 lakes in Province 7 are larger than 25 acres (Humphrys and Green, 1962). Gull Lake in Kalamazoo County is the largest lake $(2,050$ acres). Most lakes are relatively small, but they are well distributed throughout most of the province; however, there are few lakes in the glaciallacustrine deposits of Macomb, St. Clair, and Sanilac Counties.

Surface water from the Detroit Metropolitan Area water-supply system now provides most of the drinking water to the highly populated area of southeastern Oakland County, including the city of Pontiac. This readily available source of high-quality water has replaced ground water as the source of water in most communities in that area. Ann Arbor, in Washtenaw County, withdraws some of its water supply from the Huron River to supplement its well fields, which draw water from glacial deposits.

\section{Quality}

Analyses of surface-water-quality data collected by the U.S. Geological Survey from 1975 through 1988 indicate that waters from most rivers in the province are generally fair when compared to drinking-water standards 
established by the U.S. Environmenta1 Protection Agency (1986a, 1986b); however, many sections of substandard quality exist along main reaches. Most river waters are high in nutrients and low in dissolved oxygen. Analyses of samples collected during low-flow periods indicate that water from most rivers contains elevated concentrations of sulfate $(40-120 \mathrm{mg} / \mathrm{L})$, chloride (20-120 $\mathrm{mg} / \mathrm{L})$, and dissolved solids $(300-500 \mathrm{mg} / \mathrm{L})$; the water is hard, especially in the eastern part of the province (Wood, 1970, p. 4-10). Selected waterquality characteristics for three of the major rivers (St. Joseph, Kalamazoo, and Huron) are 1 isted in table 2 (at back of report).

\section{Ground Water}

Conditions for recharge are favorable in most of Province 7 . Average recharge ranges from 7 to $10 \mathrm{in} / \mathrm{yr}$. Differences within glacial deposits, however, result in wide variations in local recharge rates. In the lacustrine clay areas of the Black River basin in Sanilac and St. Clair Counties, recharge is less than $3 \mathrm{in} / \mathrm{yr}$ (Knutilla, 1970). In the sand dunes area of western Van Buren County, recharge is as high as $18 \mathrm{in} / \mathrm{yr}$ (Cummings and others, 1984 , p. 78).

Ground-water levels differ considerably throughout Province 7. Locally, some wells screened in glacial deposits flow at land surface. The maximum depth to water in the glacial deposits was $98 \mathrm{ft}$ below 1 and surface, in Kalamazoo County in 1988 (based on water levels in 127 wells measured by the U.S. Geological Survey).

\section{Availability}

Ground-water resources in Province 7 are abundant; however, production is almost entirely from glacial deposits, which range from 100 to $600 \mathrm{ft}$ in thickness (Passero and others, 1981, p1. 15). Yields greater than $500 \mathrm{gal} / \mathrm{min}$ are common for wells screened in coarse-textured sand and gravel outwash plains in the southwestern and southeastern parts of the province. The Kalamazoo-Portage metropolitan area is the second largest user of ground water in the State ( 8 billion gal/yr), all withdrawn from glacial deposits (Huffman and Whited, 1988, p. 23). In contrast, ground-water yields are limited (less than $10 \mathrm{gal} / \mathrm{min}$ ) in Branch and Hillsdale Counties where glacial deposits are thin, (Twenter, 1966b, pl. b). Mississippian bedrock, consisting mostly of the Coldwater Shale, underlies glacial deposits throughout the province, and it is extremely low yielding (less than $5 \mathrm{gal} / \mathrm{min}$ ) (Twenter, 1966a, p1. b).

\section{Quality}

Most glacial deposits supply abundant quantities of good-quality water (Michigan Water Resources Commission, 1968a, p. 37; 1968c, p. 49). The water is commonly hard and, it commonly contains high concentrations of iron ( $>1.0 \mathrm{mg} / \mathrm{L}$ ) (Cummings, 1981, p. 13-16). In the southwestern part of Province 7 , concentrations of nitrate in ground water can be high $(10-30 \mathrm{mg} / \mathrm{L})$ (Rheaume, 1990 , p. 52). 


\section{Province 8--Central Lower Peninsula}

Province 8 , which is approximately $6,050 \mathrm{mi}^{2}$ in area, is in the central part of the Lower Peninsula (p1.1). The province is characterized by glacial deposits of variable thickness that overlie high-yielding Pennsylvanian aquifers. In the northern part of the province, glacial deposits and bedrock are productive aquifers; however, in the southern part, where glacial drift is thinner, only the underlying Pennsylvanian sandstones are capable of providing yields suitable for municipal ground-water supply.

\section{Physical Setting}

Most of Province 8 is in the Saginaw Lowlands, a subdivision of the Central Lowl and physiographic division (fig. 1). The topography ranges from flat glacial-lake plains in the northeastern part to low rolling moraines and till plains in the southern and western parts. Land-surface elevation ranges from about 1,000 ft above sea level in Jackson, Ingham, and Eaton Counties to $580 \mathrm{ft}$ near Lake Huron.

The primary land use in Province 8 is agricultural. The area is moderately populated. Most of the population is concentrated in Flint (pop. 159,611), Lansing (pop. 130,414), Jackson (pop. 39,739), Mount Pleasant (pop. 23,746), and Owosso (pop. 16,455) (U.S. Bureau of Census, 1982).

\section{Surface Water}

Surface-water drainage in the southern part of the province (Subprovince $8 \mathrm{~m}$ ) is to the southwest toward Lake Michigan. Surface-water drainage in the northern part (subprovince $8 \mathrm{~h}$ ) is toward Saginaw Bay (Lake Huron).

\section{Availability}

The headwaters of numerous major rivers provide drainage in Province 8. Selected streamflow characteristics for the four largest rivers (Tittabawassee, Grand, Shiawassee, and Rifle) are listed in table 1 (at back of report). The Grand is the only river that flows west to Lake Michigan; all the other rivers flow toward Saginaw Bay (Lake Huron).

The Tittabawassee is the largest river, and most of its drainage basin is in the province. The minimum discharge for the streamflow-gaging station at Midland on the Tittabawassee River (site 29, $\mathrm{fig}$. 11) was $111 \mathrm{ft}^{3} / \mathrm{s}$ on August 21, 1949; the maximum discharge was $38,700 \mathrm{ft}^{3} / \mathrm{s}$ on September, 13, 1986.

About 170 lakes in Province 8 are larger than 25 acres (Humphrys and Green, 1962). Most lakes are relatively small and are located in either the glacial outwash of Jackson County or the lacustrine sands of Gladwin, Ogemaw, and Iosco Counties. Few lakes are located in the center of the province in the area covered by glacial lacustrine clay. Wixom Lake in Gladwin County is the largest lake ( 1,980 acres). 
Surface water from the Detroit Metropolitan Area water-supply system provides water to much of the highly populated area in central Genesee County, including the city of Flint (Bedel1, 1982, p. 24). This is primarily due to the presence of saline ground water at shallow depths in bedrock, low yields from glacial deposits, or degradation of local sources of surface water in that area (Baltusis and others, 1991).

Quality

Analyses of surface-water-quality data collected by the U.S. Geological Survey from 1975 through 1988 indicate that waters from rivers in the province differ considerably in quality when compared to drinking-water standards established by the U.S. Environmental Protection Agency (1986a, 1986b). Water quality ranges from good in the northern basins (Rifle and Au Gres River), to fair in the Grand River basin in the lower portion of the province, to degraded in most major tributaries of the Saginaw River basin in the central part. Analyses of samples collected during low-flow periods in the Saginaw River basin indicated that these river waters contain elevated concentrations of sulfate $(40-80 \mathrm{mg} / \mathrm{L})$, chloride $(20-80 \mathrm{mg} / \mathrm{L})$, and dissolved solids (300-500 mg/L); the water is also hard (Wood, 1970, p. 4-10). Selected waterquality characteristics for the Tittabawassee and Rifle Rivers are 1 isted in table 2 (at back of report).

\section{Ground Water}

Ground-water recharge in Province 8 ranges from less than 4 in/yr in lacustrine sand and clay bordering Saginaw Bay to about 7 in/yr in the coarsegrained outwash in the northwestern part of the province. The ground-water recharge rate in the outwash and till plain areas of Clinton, Eaton, and Ingham Counties was estimated as $5 \mathrm{in} / \mathrm{yr}$ by Vanlier and others $(1973, \mathrm{p} .13)$.

Ground-water levels differ throughout the province. Locally, some wells drilled into the Pennsylvanian bedrock flow at land surface. The maximum depth to water in the glacial deposits was $89 \mathrm{ft}$ below land surface, in Ionia County in 1964 (based on water levels in 40 wells measured by the U.S. Geological Survey). The maximum depth to water in the Pennsylvanian bedrock was $178 \mathrm{ft}$ below land surface, in Ingham County in 1968 (based on water levels in 33 wells measured by the U.S. Geological Survey). In the Lansing area, where Pennsylvanian sandstones are the principal ground-water source, a cone of depression extending about $100 \mathrm{mi}^{2}$ was reported by Vanlier and others, $(1973$, p. 100). In 1968 , water levels near the center of the cone were as much as $160 \mathrm{ft}$ below the prepumping level (Mandle and West john, 1988, p. 85).

\section{Availability}

Ground-water resources in Province 8 are abundant in most areas (Michigan Water Resources Commission, 1968d, p. 49). Principal aquifers of the province are Pennsylvanian sandstones of the Grand River and Saginaw Formations; however, a number of small communities and most rural residents obtain adequate water supplies from wells screened in the overlying glacial deposits. 
Glacial deposits range from 25 to $500 \mathrm{ft}$ in thickness (Passero and others, 1981, pl. 15). Deposits are thickest in the northwestern part of the province and are thinner to the south and east. Composition of the deposits ranges from medium-grained outwash and glacial till in the northern, southern, and western parts to lacustrine sand and clay in the eastern part. Groundwater production from glacial deposits is greatest in the northwestern part, where wells 8 in. or more in diameter yield from 100 to $500 \mathrm{gal} / \mathrm{min}$ (Twenter, $1966 \mathrm{~b}, \mathrm{pl}$. b). Well yields from glacial deposits are generally lower throughout the rest of the province (10 to $100 \mathrm{gal} / \mathrm{min}$ ) because deposits are thinner and (or) consist of fine-grained, less permeable materials.

Pennsylvanian bedrock underlies glacial deposits throughout most of Province 8. The Grand River and Saginaw formations, consisting primarily of sandstone, shale, and limestone, are extensively used in the southern half of the province as a source of water for most public water systems. The Lansing metropolitan area withdraws the largest amount of ground water in the State ( 10 billion gal/yr), mostly from the Saginaw Formation (Huffman and Whited, 1988 , p. 21).

Throughout most of the province, wells 10 in. or more in diameter drilled into aquifers in the Pennsylvanian rocks will yield from 100 to $500 \mathrm{gal} / \mathrm{min}$ (Twenter, 1966a, p1. a); however, yields depends on degree of fracturing, number of bedding-plane fractures, thickness of the sandstone, and the volumetric ratio of sandstone to shale. These formations are confined in most places. Near Lansing, transmissivity ${ }^{4}$ ranges from 130 to $3,300 \mathrm{ft}^{2} / \mathrm{d}$ (Grannemann and others, 1985, p. 258).

In the three northern counties (Ogemaw, Arenac, and Iosco), Mississippian bedrock of the Michigan Formation and Marshall Sandstone underlie glacial deposits. These formations consist of light-colored, fine- to medium-grained sandstone, and they can produce large quanitities of freshwater. They are seldom used, however, because sufficient ground-water supplies can be obtained from the overlying glacial deposits.

\section{Quality}

Ground-water quality in Province 8 is extremely variable, owing principally to variable geology (Michigan Water Resources Commission, 1968d, p. 49). In some areas, wells screened in glacial deposits produce low yields of poor-quality water, especially in lacustrine clay and silt. Elsewhere in the province, many communities and residents obtain ample supplies of freshwater from the lacustrine sands; however, water from these glacial deposits is very hard and commonly contains high concentrations of iron (> $1.0 \mathrm{mg} / \mathrm{L}$ ) (Cummings, 1989, p. 13-16).

4 In this report, transmissivity is reported in feet squared per day $\left(\mathrm{ft}^{2} / \mathrm{d}\right)$, a mathematical reduction of the unit of cubic feet per day per square foot times feet of aquifer thickness $\left(\left[\left(\mathrm{ft}^{3} / \mathrm{d}\right) / \mathrm{ft}^{2}\right] \mathrm{ft}\right)$. 
Ground water from the Grand River and Saginaw Formations of Pennsylvanian age generally is hard and contains high dissolved-solids concentrations (400-2,000 mg/L) (Cummings, 1989, p. 13-16). Dissolved-solids concentrations are generally lower $(300-800 \mathrm{mg} / \mathrm{L})$ in areas where the aquifer is used for large municipal supplies, such as in the Lansing area. Problems with upward migration and withdrawal of saline water, however, have developed periodically in the municipalities of Lansing and Mount Pleasant (Mandle and Westjohn, 1988 , p. 85). In the Flint area, Pennsylvanian and Mississippian sandstones were used for public supply until excessive pumping induced the migration of saline water; this resulted in abandonment of these well fields (Wiitala and others, 1963, p. 59).

\section{Province 9--South-Central Lower Peninsula}

Province 9 includes an area of approximately $5,470 \mathrm{mi}^{2}$ of the southcentral part of the Lower Peninsula ( 1 l. 1). The province is characterized by thin to moderately thick glacial drift that overlies high-yielding aquifers in Mississippian bedrock. In areas where drift is thick and coarse grained, aquifers in glacial deposits and Mississippian bedrock are used for water supplies. Where drift is thin or of low permeability, the aquifers in Mississippian rocks are the only available ground-water source. Most large communities in Province 9 use wells drilled into Mississippian rocks for most of their ground-water supplies.

\section{Physical Setting}

Most of Province 9 is located in the Thumb Uplands, a subdivision of the Central Lowland physiographic division (fig. 1). The topography is mostly rolling and consists of upland moraines between outwash and till plains. Land-surface elevation ranges from $580 \mathrm{ft}$ above sea level along the Lake Huron shoreline to about $1,100 \mathrm{ft}$ on moraines in the south-central part of the State.

Province 9 is moderately populated. Land use consists of a fairly even mixture of farms, forest, and small urban centers. The largest cities are Battle Creek (pop. 35,724), Albion (pop. 11,059), Hillsdale (pop. 7,432), and Howell (pop. 6,976) (U.S. Bureau of Census, 1982).

\section{Surface Water}

Surface-water drainage in the western half of the province (Subprovince $9 \mathrm{~m}$ ) is northwestward toward Lake Michigan. Surface-water drainage in the eastern half is split between northwestward flow toward Lake Huron's Saginaw Bay (Subprovince $9 \mathrm{~h}$ ) and southeastward flow toward Lake Erie and the St. Clair-Detroit River system (Subprovince $9 e$ ).

\section{Availability}

Parts of eight major rivers (Grand, Kalamazoo, St. Joseph, Raisin, Huron, Shiawassee, F1 int, and Cass) drain Province 9. The Kalamazoo River has the largest drainage area in the province. Selected streamflow characteristics for the streamflow-gaging station at Comstock on the Kalamazoo River (site 13, 
fig. 11) are 1 isted in table 1 (at back of report). The minimum discharge for the period of record was $185 \mathrm{ft}^{3} / \mathrm{s}$ on August 7, 1934; the maximum discharge was $6,910 \mathrm{ft}^{3} / \mathrm{s}$ on Apri1 8, 1947 .

About 300 lakes in Province 9 are larger than 25 acres (Humphrys and Green, 1962). Gun Lake in Barry County is the largest lake (2,680 acres). Most lakes are relatively small, but they are fairly evenly distributed throughout the province. The exception is in the lacustrine sand and clay areas of Huron, Tuscola, and Sanilac Counties, where lakes are few.

Surface water from the Detroit Metropolitan Area water-supply system provides for the water needs of Lapeer and Imlay City in Lapeer County. In the late $1960^{\prime} \mathrm{s}$, both cities abandoned their wells, which were drilled into Mississippian sandstones, because of water-quality problems such as high chloride concentrations. These cities then connected to the newly established water-supply 1 ine from Detroit to the Flint area. Port Austin and Caseville, in Huron County, withdraw surface water from Lake Huron. Both towns initially pumped ground water from Mississippian sandstones, but this source was abandoned by Port Austin in 1967 and by Caseville in 1989 because of high concentrations of chloride and the water was hard (Baltusis and others, 1991).

Quality

Analyses of surface-water-quality data collected by the U.S. Geological Survey from 1975 through 1988 indicate that waters from rivers in the province differ considerably in quality when compared to drinking-water standards established by the U.S. Environmental Protection Agency (1986a, 1986b). Water quality ranges from fair to good in the headwaters of most rivers, to substandard along many of the main reaches. High concentrations of nutrients and sediment are common problems. Analyses of samples collected during lowflow periods indicate that water from most rivers in the province contain elevated concentrations of sulfate $(40-120 \mathrm{mg} / \mathrm{L})$, chloride $(10-30 \mathrm{mg} / \mathrm{L})$, and dissolved solids (200-400 mg/L); the water is also hard (Wood, 1970, p. 4-10). Selected water-quality characteristics for the Kalamazoo River are 1 isted in table 2 (at back of report).

\section{Ground Water}

Recharge to aquifers in Province 9, which ranges from 4 to $13 \mathrm{in} / \mathrm{yr}$, is primarily through glacial and lacustrine deposits; however, permeable sandstones at or near the surface in some areas have large infiltration capacities (Grannemann and Twenter, 1985, p. 21). Recharge is highest in glacial outwash in the southwestern part of the province and lowest in the lacustrine clay of Huron County.

Ground-water levels differ considerably throughout Province 9. Locally, some wells drilled into the Mississippian bedrock flow at land surface. The maximum depth to water in the glacial deposits was $121 \mathrm{ft}$ below land surface, in Barry County in 1965 (based on water levels in 14 wells measured by the U.S. Geological Survey). The maximum depth to water in the Mississippian bedrock was $82 \mathrm{ft}$ below land surface, in Tuscola County in 1957 (based on water levels in 25 wells measured by the U.S. Geological Survey). 


\section{Availability}

Ground-water yields in Province 9 are abundant in most places (Michigan Water Resources Commission, 1968c, p. 46; 1968d, p. 49). Al though the principal aquifers of the province are Mississippian sandstones, a few small communities and many rural residents use wells that are screened in glacial deposits.

Glacial deposits are absent at some locations, but they can be as much as $400 \mathrm{ft}$ thick in other areas (Passero and others, 1981, p1. 15). Deposits consist primarily of medium-grained outwash, till plains, and moraines, except in Huron County where the deposits are predominately glacial lacustrine clay and silt. Well yields are highest (greater than $500 \mathrm{gal} / \mathrm{min}$ ) in thick outwash of Allegan, Barry, Oakland, and Washtenaw Counties. Well yields are lowest (1ess than $10 \mathrm{gal} / \mathrm{min}$ ) in Hillsdale and Jackson Counties where the drift is thin and in Huron County where lacustrine deposits are of low permeability (Twenter, 1966b, pl. b).

Mississippian bedrock consisting mostly of the Marshall Sandstone underlies the glacial deposits. The Marshall Sandstone is the most productive bedrock aquifer in the state. Although it underlies much of the Lower Peninsula, it is extensively used as an aquifer only in this province; elsewhere in the Lower Peninsula, ground water from the Marshall Sandstone is either too saline for use or less economical to develop than water from other aquifers that are closer to the land surface (Grannemann and others, 1985, $p$. 285).

Transmissivities for the Marshall Sandstone range from 2,700 to $67,000 \mathrm{ft}^{2} / \mathrm{d}$ (Vanlier, 1966, p. 19), depending primarily on differences in aquifer thickness and the size and number of fractures. Transmissivity increases to the southwest and decreases to the northeast. The most productive areas (yields greater than $1,000 \mathrm{gal} / \mathrm{min}$ ) are in Barry, Calhoun, and Jackson Counties (Twenter, 1966a, pl. a).

\section{Quality}

Ground-water quality in Province 9 generally is good in the glacial deposits and in the Mississippian bedrock, although most water supplies contain high concentrations of iron $(>1.0 \mathrm{mg} / \mathrm{L})$; the water is also hard (Cummings, 1989, p. 13-16). Water from the Marshall Sandstone generally contains a dissolved-solids concentration of less than $500 \mathrm{mg} / \mathrm{L}$ (Grannemann and others, 1985, p. 258); however, in the northeastern counties of the province, high concentrations of sodium (30-300 $\mathrm{mg} / \mathrm{L})$, chloride $(50-400 \mathrm{mg} / \mathrm{L})$, and sulfate $(30-200 \mathrm{mg} / \mathrm{L})$ in water from the Mississippian bedrock are common.

\section{Province 10--Southeastern Lower Peninsula}

Province 10, which is $625 \mathrm{mi}^{2}$ in area, is the smallest province in the state. It is in the southeastern corner of the Lower Peninsula (p1. 1). The province is characterized by thin, low-yielding glacial lacustrine clay that overlies aquifers in Silurian and Devonian bedrock. These bedrock aquifers are moderate in yield, but they can contain highly mineralized water. Most 
communities rely on surface water for their water-supply needs; however, some small inland communities and the rural population rely on ground water from wells drilled into the bedrock.

\section{Physical Setting}

Province 10 is in the Erie Lowlands, a subdivision of the Central Lowland physiographic division ( $f i g .1$ ). The topography is rather flat and featureless and consists mainly of clayey till reworked in glacial lakes and veneered by lacustrine sand, silt, and clay (Mozola, 1970, p. 6). Landsurface elevation ranges from $700 \mathrm{ft}$ above sea level in northwestern Monroe County to about $572 \mathrm{ft}$ along the Lake Erie shoreline. This flatness of the land results in the low velocities of most streams. Surface-water drainage in the province (Subprovince 10e) is southeastward toward Lake Erie.

The province is moderately populated, and most residents and industry are along the Lake Erie shoreline. Agriculture is the dominant land use; however, farming is practiced mostly in the western part of the province, away from Lake Erie. Monroe (pop. 23,531), Trenton (pop. 22,762), and Flat Rock (pop. 6,853 ) are the largest cities (U.S. Bureau of Census, 1982).

\section{Surface Water}

\section{Availability}

Two major rivers, the Raisin and the Huron, and a number of minor streams drain Province 10. All rivers flow southeast toward Lake Erie. The River Raisin is the largest river system in the province. Selected streamflow characteristics for the gaging station at Monroe on the River Raisin (site 38, fig. 11) are listed in table 1 (at back of report). The minimum discharge for the period of record at this station was $2 \mathrm{ft}^{3} / \mathrm{s}$ on September 4, 1941; the maximum discharge was $15,300 \mathrm{ft}^{3} / \mathrm{s}$ on March 16, 1982.

About 15 lakes in Province 10 are larger than 25 acres (Humphrys and Green, 1962). All lakes are relatively small, and none are larger than 300 acres.

Most communities in the province rely on surface water for their water supply, much of which comes from Lakes Huron or Erie, either through the Detroit or the Monroe distribution systems. The inland communities of Flat Rock and Rockwood withdraw surface water from the Huron River; Dundee withdraws water from the River Raisin.

Quality

Analyses of surface-water-quality data collected by the U.S. Geological Survey from 1975 through 1988 indicate that waters from all major rivers and streams in Province 10 are considered only fair when compared to drinkingwater standards established by the U.S. Environmental Protection Agency $(1986 a, 1986 \mathrm{~b})$. All rivers have sections of degraded quality along main reaches. River waters are high in nutrients, with concentrations increasing with distance downstream. Analyses of samples collected during low-flow periods indicate that water from all rivers in the province contain elevated concentrations of sulfate $(80-120 \mathrm{mg} / \mathrm{L})$, chloride $(20-40 \mathrm{mg} / \mathrm{L})$, and dissolved 
solids (400-500 mg/L); the water is also hard (Wood, 1970, p. 4-10). Selected water-quality characteristics for the River Raisin are 1 isted in table 2 (at back of report).

\section{Ground Water}

Recharge to bedrock aquifers in Province 10 is 1 imited by overlying lacustrine clay. Average ground-water recharge for the province ranges from 2 to $4 \mathrm{in} / \mathrm{yr}$ (Twenter and others, 1975).

Ground-water levels do not differ significantly throughout Province 10. The maximum depth to water in the Silurian and Devonian bedrock was $45 \mathrm{ft}$ below land surface, in northwestern Monroe County in 1977 (based on water levels in nine wells measured by the U.S. Geological Survey). Some wells near Lake Erie that have been drilled into Silurian and Devonian bedrock flow at land surface.

Availability

Ground-water use in the heavily populated eastern part of Province 10 is limited because of poor ground-water quality and to the readily available supply of surface water. Nevertheless, bedrock aquifers provide adequate amounts of water for some communities that are distant from Lake Erie, and bedrock is the principal source of water supply for all rural areas.

Glacial deposits range in thickness from less than 1 to nearly $100 \mathrm{ft}$; however, deposits are typically less than $30 \mathrm{ft}$ thick (Passero and others, $1981, \mathrm{p} 1.15)$. These deposits are seldom adequate as a water-supply source because of high percentages of clay and silt and corresponding low permeability. Well yields are usually less than $5 \mathrm{gal} / \mathrm{min}$ (Mozola, 1970, p. 1). Glacial deposits are sometimes used as a source of domestic supply in the western part of the province, where they are thicker and coarser grained than in the eastern part.

The glacial deposits are underlain by Silurian and Devonian 1 imestone and dolomite with some sandstone and shale. Throughout most of the province, wells 8 in. or more in diameter that are drilled into bedrock will yield 100 to $500 \mathrm{gal} / \mathrm{min}$ (Twenter, 1966a, pl. a).

Quality

Ground-water quality in Province 10 generally is poor (Michigan Water Resources Commission, $1968 \mathrm{a}$, p. 38). More than 90 percent of the wells are completed in bedrock because of the high clay content in the overlying thin glacial drift (Mozola, 1970, p. 1). Ground water from aquifers in Silurian and Devonian rocks is very hard and commonly contains high concentrations of dissolved solids $(400-2,000 \mathrm{mg} / \mathrm{L})$, iron $(>1.0 \mathrm{mg} / \mathrm{L})$, and sulfate $(50-1,000$ $\mathrm{mg} / \mathrm{L}$ ) (Cummings, 1989, p. 13-16). In general, mineralization of ground water increases as depth from land surface increases. Ground water associated with carbonate rocks is commonly impaired by hydrogen sulfide, which can be recognized by its disagreeable "rotten eggs" odor. 


\section{Province 11--Eastern Lower Peninsula}

Province 11 includes approximately $2,060 \mathrm{mi}^{2}$ of the southeastern part of the Lower Peninsula ( $p 1.1)$. The province is characterized by moderately thick, low-yielding, glacial lacustrine clay that overlies low-yielding Devonian and Mississippian shale and sandstone containing highly mineralized water. The glacial deposits and bedrock are generally incapable of yielding adequate ground-water supplies. The province relies heavily on surface water, mostly from Lakes Huron and Erie.

\section{Physical Setting}

Most of Province 11 is in the Erie Lowlands, a subdivision of the Central Lowland physiograpic division (fig. 1). The topography ranges from flat to gently rolling in the glacial lakebed plains bordering Lakes Huron and Erie. Glacial deposits consist mainly of reworked silty-clayey till and lacustrine deposits that contain discontinuous stringers of sand and gravel (Gillespie and Dumouchelle, 1989 , p. 5). Land-surface elevation ranges from about $575 \mathrm{ft}$ above sea level along the shoreline of the Detroit River to $850 \mathrm{ft}$ in southeastern Oakland County. Most of the province is less than $700 \mathrm{ft}$ in elevation.

This province includes one of the most heavily populated and industrialized areas in the Great Lakes Basin. Almost 3 million people, a third of Michigan's population, reside in this area.

\section{Surface Water}

Surface-water drainage in the southern two-thirds of the province (Subprovince $1 \mathrm{le}$ ) is southeastward toward Lake Erie. Surface-water drainage in the northern third of the province (Subprovince $11 \mathrm{~h}$ ) is eastward toward Lake Huron.

\section{Availability}

Parts of six major rivers (Raisin, Huron, Rouge, $\mathrm{Cl}$ inton, Belle, and Black) and a number of minor streams drain Province 11 . The Clinton River is the largest. Selected streamflow characteristics for the gaging station at Mount Clemens on the Clinton River (site 34, fig. 11) are 1isted in table 1 (at back of report). The minimum discharge is not available; however, the maximum discharge for the period of record was $21,200 \mathrm{ft}^{3} / \mathrm{s}$ on April 6, 1947 .

About 50 inland lakes in Province 11 are larger than 25 acres (Humphrys and Green, 1962). Most lakes are small. Ford Lake (1,049 acres), an impoundment on the Huron River in Washtenaw County, is the largest.

Quality

Analyses of surface-water-quality data collected by the U.S. Geological Survey from 1975 through 1988 indicate that waters from all major rivers and streams in Province 11 are considered poor when compared to drinking-water standards established by the U.S. Environmental Protection Agency (1986a, $1986 \mathrm{~b})$. All rivers have sections of degraded quality along main reaches. 
Most rivers receive industrial and sewage effluent that contributes large amounts of dissolved solids and nutrients and reduce dissolved-oxygen concentration. Analyses of samples collected during low-flow periods indicate that water from most rivers contains elevated concentrations of sulfate (40$120 \mathrm{mg} / \mathrm{L})$, chloride $(30-120 \mathrm{mg} / \mathrm{L})$, and dissolved solids $(300-500 \mathrm{mg} / \mathrm{L})$; the water is also hard (Wood, 1970, p. 4-10). Selected water-quality characteristics for the Clinton River are listed in table 2 (at back of report).

\section{Ground Water}

Recharge in Province 11 is limited because of the lacustrine deposits. Ground-water recharge ranges from $1 \mathrm{in} / \mathrm{yr}$ in clay-rich till (Knutilla, 1970) to $5 \mathrm{in} / \mathrm{yr}$ in fine to medium sands (Gillespie and Dumouchelle, 1989, p. 28). The average ground-water recharge in Province 11 is about 3 in/yr.

Ground-water levels do not differ significantly throughout Province 11. The maximum depth to water in the glacial deposits was $19 \mathrm{ft}$ below 1 and surface, in Oakl and County in 1964 (based on water levels in 20 wells measured by the U.S. Geological Survey). Water levels in three wells drilled into the Coldwater Shale of Mississippian age in Huron County ranged from 8 to $45 \mathrm{ft}$ below land surface. Locally, some wells screened in glacial deposits flow at land surface.

\section{Availability}

Ground-water supplies are not adequate to supply the needs of area residents; only surface-water sources from the Great Lakes can meet this demand. The Detroit Metropolitan Area water-supply system provides about $500 \mathrm{Mgal} / \mathrm{d}$ of surface water for the province (Sweat, 1990, p. 307).

Glacial lakebed plains, composed mainly of silt and clay that range from 50 to $400 \mathrm{ft}$ in thickness, cover most of Province 11 (Passero and others, 1981, pl. 15). These deposits are seldom adequate as a source of water supply because of their low permeability. Most wells completed in glacial deposits will yield only small quantities of water, usually less than $10 \mathrm{gal} / \mathrm{min}$ (Twenter, 1966b, pl. b); however, small areas in Macomb, Oakland, Washtenaw, Wayne, and Monroe Counties contain reworked alluvium along river channels that is capable of producing as much as $500 \mathrm{gal} / \mathrm{min}$ of freshwater from shallow we11s.

The Coldwater Shale, Berea Sandstone, Bedford Shale, and Antrim Shale, of Devonian and Mississippian age, underlie the glacial deposits. Most of these formations are low yielding (less than $10 \mathrm{gal} / \mathrm{min}$ ), and the water is usually too highly mineralized to be used as a water supply (Twenter, 1966a, pl. a).

\section{Quality}

Water quality in the lacustrine deposits and in the Devonian and Mississippian bedrock is generally poor (Michigan Water Resources Commission, $1968 \mathrm{a}$, P. 37 ; 1968d, p. 49). The water often contains high concentrations of iron ( $>1.0 \mathrm{mg} / \mathrm{L}$ ) and dissolved solids $(400-20,000 \mathrm{mg} / \mathrm{L})$, and it is hard (Cummings, 1989 , p. 13-16). High concentrations of sodium $(100-10,000 \mathrm{mg} / \mathrm{L}$ ) and chloride $(250-15,000 \mathrm{mg} / \mathrm{L})$ are common. 


\section{Province 12--East-Central Lower Peninsula}

Province 12 includes approximately $1,550 \mathrm{mi}^{2}$ of the east-central part of Michigan's Lower Peninsula ( $\mathrm{pl}, 1)$. The province is characterized by low yielding, glacial-lake plains of variable thickness that overlie sandstone aquifers in Pennsylvanian and Mississippian rocks. The sandstone aquifers contain highly mineralized water. Fresh ground water is difficult to obtain; therefore, most communities rely on surface water from Lake Huron for their water-supply needs.

\section{Physical Setting}

Most of Province 12 is in the low-lying glacial lake area referred to as the Saginaw Lowlands, a subdivision of the Central Lowland physiographic division ( $f i g .1$ ). The topography consists of flat and featureless lacustrine sand and clay. Land-surface elevation ranges from about $580 \mathrm{ft}$ above sea level along the shoreline of Saginaw Bay to slightly more than $700 \mathrm{ft}$ in the inland areas of Midland and Saginaw Counties. Surface-water drainage in the province (Subprovince $12 \mathrm{~h}$ ) is toward Saginaw Bay. A large percentage of the land is artificially drained.

The province is moderately populated. Most of the residents and industry are concentrated in small sections of Saginaw, Midland, and Bay Counties. Land use is predominantly forestry in the north and agriculture and industry in the south. Saginaw (pop. 77,500), Bay City (pop. 41,600), and Midland (pop. 37,250) are the largest cities (U.S. Bureau of Census, 1982).

Surface Water

\section{Availability}

The Saginaw River basin includes most of Province 12. Four major tributaries, the Tittabawassee, Shiawassee, Flint, and Cass River, come together in Saginaw County to form the Saginaw River. Selected streamflow characteristics for the gaging station at Saginaw on the Saginaw River (site 31, fig. 11) are listed in table 1 (at back of report). The maximum discharge for the period of record at this station was $68,000 \mathrm{ft}^{3} / \mathrm{s}$ on March 30, 1904; flooding is a serious problem in many places in the province. The minimum discharge for the Saginaw River is unavailable.

About 25 lakes in Province 12 are 1 arger than 25 acres (Humphrys and Green, 1962). Tawas Lake in Iosco County is the largest lake (1,600 acres).

Almost all communities in Province 12 rely on surface water from Lake Huron. Many nearshore communities withdraw water directly from Saginaw Bay; most population centers further inland have connected to the extensive Saginaw-Midland water supply system, which withdraws about $200 \mathrm{Mgal} / \mathrm{d}$ from the Bay (Sweat, 1990 , p. 307).

Quality

Analyses of surface-water-quality data collected by the U.S. Geological Survey from 1975 through 1988 indicate that waters from all major rivers and streams in Province 12 are considered poor when compared to drinking-water 
standards established by the U.S. Environmental Protection Agency (1986a, 1986b). Many areas of the Saginaw River system have been degraded by urban and industrial runoff and discharge. Analyses of samples collected during low-flow periods indicate that water from most tributaries of the Saginaw River contain elevated concentrations of sulfate $(20-120 \mathrm{mg} / \mathrm{L})$, chloride (10$80 \mathrm{mg} / \mathrm{L}$ ), and dissolved solids $(200-500 \mathrm{mg} / \mathrm{L})$; the water is also hard (Wood, 1970 , p. 4-10). Selected water-quality characteristics for the Saginaw River are 1 isted in table 2 (at back of report).

\section{Ground Water}

Recharge in the province is limited because of the lakebed deposits. Ground-water recharge ranges from 2 in/yr in flat, low 1 ying areas of lacustrine clay and silt near Saginaw Bay to $5 \mathrm{in} / \mathrm{yr}$ in fine to medium sands of former Great Lakes beaches in western Midland and Saginaw Counties (Michigan Water Resources Commission, 1960, p. 39, and 1963, p. 24). Average ground-water recharge for Province 12 is about $4 \mathrm{in} / \mathrm{yr}$.

Ground-water levels do not differ significantly throughout Province 12. The maximum depth to water in the glacial deposits was $8 \mathrm{ft}$ below land surface, in Saginaw County in 1984 (based on water levels in three wells measured by the U.S. Geological Survey). The maximum depth to water in the Pennsylvanian bedrock was $30 \mathrm{ft}$ below land surface, in Saginaw County in 1978 (based on water levels in 15 wells measured by the U.S. Geological Survey). Locally, some wells screened in glacial deposits and some wells drilled into Pennsylvanian bedrock flow at land surface.

\section{Availability}

Ground-water resources in Province 12 are characterized by either $10 \mathrm{w}$ yields or problems with quality (Michigan Water Resources Commission, 1968d, p. 49). Glacial-lakebed deposits range from 25 to $300 \mathrm{ft}$ in thickness (Passero and others, 1981, pl. 15), but most of these deposits contain high percentages of clay, silt, and fine sand, and they are generally of low permeability. Throughout most of the province, wells screened in glacial deposits yield less than $10 \mathrm{gal} / \mathrm{min}$ (Twenter, 1966b, pl. b). In many areas surrounding Saginaw Bay, fresh ground water is unavailable. The glacial drift is thin, and the underlying bedrock contains saline water.

A small section of the province in Arenac and Alcona Counties is underlain by the Marshall Sandstone of Mississippian age. Most of Province 12 is underlain by the Saginaw Formation of Pennsylvanian age, which consists primarily of sandstone interbedded with shale, limestone, coal, and gypsum. The Mississippian and Pennsylvanian bedrock formations are both capable of producing large quantities ( 50 to $500 \mathrm{gal} / \mathrm{min}$ ) of ground water, but throughout most of the province, wells drilled into bedrock yield water that is too highly mineralized for domestic or public supplies (Twenter, 1966a, pl. a).

\section{Quality}

Ground-water quality in Province 12 is extremely poor (Michigan Water Resources Commission, 1968d, p. 49). Ground water typically is very hard and contains high concentrations of iron $(>1.0 \mathrm{mg} / \mathrm{L})$ and dissolved solids $(1,000-$ $5,000 \mathrm{mg} / \mathrm{L}$ ) (Cummings, 1989, p. 13-16). Throughout most of the province, the 
Mississippian and Pennsylvanian bedrock contains saline water. The amount of dissolved solids, principally chloride, is laterally and vertically variable. Laterally, the chloride concentrations generally increases to the west and south. Concentrations range from near the recommended U.S. Envi ronmental Protection Agency maximum contaminant level for drinking water $(250 \mathrm{mg} / \mathrm{L})$ to as much as several thousand milligrams per liter near the south side of Saginaw Bay. The chloride content of the ground water also tends to increase with depth.

Saline ground water is commonly encountered at an elevation of about $500 \mathrm{ft}$ above sea level, which in some places is at a depth of less than $100 \mathrm{ft}$ below land surface ( $f$ ig. 10 ). In some of these areas, saline water is encountered in the basal part of the glacial drift (Westjohn, 1988, p. 128). In the northern part of the province, water in the Michigan Formation (Mississippian) is mineralized primarily because of the presence of gypsum beds (Michigan Water Resources Commission, 1968d, p. 49). 


\section{SUMMARY}

The two prinicipal physiographic provinces in Michigan are the Superior Upland in the western Upper Peninsula and the Central Lowland in the remainder of the State. The Superior Upland is underlain by igneous, metamorphic, and sedimentary rocks of Precambrian age. The Central Lowland is underlain by sedimentary bedrock of Precambrian, Paleozoic, and Mesozoic ages. Glacial deposits cover most of the State. Topography ranges from level to gently rolling in the eastern part of the Upper Peninsula and southern part of the Lower Peninsula to hilly and rugged in the western part of the Upper Peninsula and north-central part of the Lower Peninsula.

Michigan borders four Great Lakes (Superior, Michigan, Huron, and Erie), which together contain nearly 20 percent of the world's fresh surface water. Nevertheless, 43 percent of the State's population depends on ground water for water supply. The principal aquifers in Michigan consist of glacial deposits and sedimentary bedrock.

Yields from glacial aquifers are highest in outwash and glaciofluvial deposits; they range from about 1 to $1,000 \mathrm{gal} / \mathrm{min}$. Lacustrine-sand aquifers typically yield 80 to $500 \mathrm{gal} / \mathrm{min}$, and till aquifers yield 5 to $200 \mathrm{gal} / \mathrm{min}$.

Among the bedrock aquifers, the Mississippian and Pennsylvanian rocks in the Lower Peninsula are the most productive; yields commonly range from 100 to $1,000 \mathrm{gal} / \mathrm{min}$. In the Upper Peninsula, the Silurian and Devonian rocks yield 10 to $100 \mathrm{gal} / \mathrm{min}$, Ordovician rocks yield 50 to $500 \mathrm{gal} / \mathrm{min}$, and Precambrian and Cambrian rocks yield 5 to $100 \mathrm{gal} / \mathrm{min}$.

Michigan has been divided into 12 provinces on the basis of similar hydrologic characteristics. As an initial step in defining these hydrologic provinces, principal bedrock aquifers were delineated on State maps on the basis of bedrock type. Province boundaries were adjusted by overlaying maps of Quaternary geology and then delineating additional principal glacialdeposit aquifers on the basis of thickness and yield. Province boundaries were further readjusted on the basis of analyses of ground water from 354 wells sampled by the U.S. Geological Survey from 1977 through 1988. Areas were identified where ground water contained high dissolved-solids concentration or where major differences in the natural ground-water quality have been noted. After province boundaries were established, they were subdivided on the basis of regional surface-water drainage to each of the four Great Lakes bordering Michigan.

Province 1 , in the western Upper Peninsula, is characterized by thin glacial deposits that overlie a Precambrian igneous and metamorphic crystalline complex consisting mainly of granite, gneiss, and schist. Groundwater resources are limited. Throughout most of the province, wells screened in glacial deposits yield less than $10 \mathrm{gal} / \mathrm{min}$. In a few areas, limited amounts of ground water can be obtained at shallow depths from the fractured and weathered Precambrian bedrock. Water quality of most rivers is generally considered excellent. Water quality in glacial deposits is generally good; however, excessive hardness and high concentrations of iron are common. The bedrock typically contains ground water that contains high concentrations of dissolved solids. 
Province 2, in the northern Upper Peninsula, is characterized by relatively thin glacial deposits that overlie Precambrian and Cambrian sandstones. Throughout most of the province, the glacial deposits and these sandstones are both capable of producing limited ground-water supplies. Water quality of most rivers and streams in the province is considered good. Ground water from most wells screened in glacial deposits and in bedrock is generally of good quality, although most supplies contain objectionable amounts of iron.

Province 3 , in the east-central Upper Peninsula, is characterized by glacial deposits of variable thickness that overlie Ordovician limestone and dolomite. The glacial deposits and the Ordovician bedrock are productive aquifers. Water quality of most rivers and streams in the province is considered good. Water quality of the glacial deposits is generally excellent. Most water is soft and contains low dissolved-solid concentrations, but concentrations of iron are high at some locations. Water quality in the Ordovician bedrock is generally good, although the water can be hard to very hard and can contain high concentrations of iron. In some areas, ground water from the Ordovician bedrock contains elevated concentrations of sodium and chloride. In these areas, deep wells drilled into the Precambrian and Cambrian sandstones commonly yield water of better quality.

Province 4, in the northern Lower and southeastern Upper Peninsula, is characterized by relatively thin, glacial-lakebed sands that overlie Silurian and Devonian limestone and dolomite. Aquifers in the Silurian and Devonian bedrock are the primary source of most ground-water supplies in the province. Where the glacial deposits are sufficiently thick, they are used as a source of domestic supply. Water quality of rivers and streams is considered good; however, the water quality in some rivers is somewhat degraded near their mouths. The quality of ground water varies with the 1 ithology and depth of the aquifers. Limestone, dolomite, and glacial deposits generally yield water that is hard to very hard and contains high concentrations of iron but that is otherwise of good quality. In some places, aquifers containing good-quality water are covered or underlain by aquifers containing water of objectionable quality.

Province 5, in the north-central Lower Peninsula, is characterized by thick, coarse-grained sandy outwash and glaciofluvial deposits, which overlie sedimentary bedrock of Devonian, Mississippian, Pennsylvanian, and Jurassic age. Many of these bedrock formations are a productive source of freshwater, but they are seldom used because of their great depth. Most domestic and municipal ground-water supplies are from sandy glacial deposits that are as much as $1,000 \mathrm{ft}$ thick in some areas. Water quality of most rivers and streams is considered good, but the water is generally hard. Some degradation has been noted in the lower reaches of the large rivers. Ground-water quality generally is good; however, high concentrations of iron and hardness are problems in a few areas.

Province 6 , in the west-central Lower Peninsula, is characterized by low yielding, glacial-lakebed deposits of variable thickness that overlie Mississippian sedimentary rocks containing highly mineralized water. Throughout most of the province, limited amounts of fresh ground water are available only in glacial deposits; therefore, large communities rely on surface water from Lake Michigan for their water-supply needs. Water quality of most rivers is consider only fair, and all major rivers have sections of 
degraded quality near their mouths. Water quality in the glacial deposits and in the Mississippian bedrock generally is poor. It often is hard to very hard and usually contains objectionable amounts of iron. High concentrations of sodium, chloride, sulfate, and dissolved solids are common.

Province 7, in the southern Lower Peninsula, is characterized by generally thick, coarse-grained outwash and glaciofluvial deposits that overlie extremely low-yielding Mississippian shale containing mineralized water. Ground-water supplies in glacial deposits generally are abundant. Water quality of most major rivers is considered fair, but many sections of degraded quality exist along main reaches. Most glacial deposits supply abundant quantities of good-quality water. The water commonly is hard and contains high concentrations of iron. In the southwestern part of the province, concentrations of nitrate in ground water can be high.

Province 8 , in the central Lower Peninsula, is characterized by glacial deposits of variable thickness that overlie high-yielding Pennsylvanian sandstone. In the northern part of the province, the glacial deposits and bedrock are productive aquifers. In the southern part, where glacial deposits are thin, only the bedrock is capable of providing an adequate ground-water supply. Most large communities derive most of their ground-water supply from aquifers in the Pennsylvanian rocks. Surface-water quality ranges from good in the northern basins, to fair in the Grand River basin, to degraded in most major tributaries of the Saginaw River basin. Ground-water quality is extremely variable, owing principally to variable geology. Water from glacial deposits is very hard and commonly contains objectionable amounts of iron. Water from Grand River and Saginaw Formations of Pennsylvanian age generally is hard and contains high dissolved-solids concentrations.

Province 9, in the south-central Lower Peninsula, is characterized by thin to moderately thick glacial drift that overlies high-yielding Mississippian sandstone and siltstone. Where drift is thick and coarse grained, glacial deposits and bedrock are both used for water supplies. Where drift is thin or of low permeability, the aquifers in the Mississippian bedrock are the only available ground-water source, and most large communities use these aquifers for most of their ground-water supplies. A few small communities and many rural residents have wells screened in glacial deposits, however. Surface-water quality in the province ranges from fair to good in the headwaters of most rivers to degraded along many of the main reaches. Ground-water quality is generally good in the glacial deposits and in the Mississippian bedrock, although high concentrations of iron and hard water are common.

Province 10, in the southern Lower Peninsula, is characterized by thin, low yielding glacial lacustrine clay that overlies aquifers in silurian and Devonian bedrock. The Silurian and Devonian rocks are moderate yielding, but they can contain highly mineralized water. Most communities can only meet their water-supply needs through surface-water withdrawals; however, some small inland communities and most of the rural population rely on the bedrock aquifers. Water quality in all major rivers and streams in the province is considered only fair, and many sections of degraded quality exist along main reaches. Ground-water quality is generally poor. Ground water from aquifers in the silurian and Devonian rocks is very hard and commonly contains high concentrations of dissolved solids, iron, and sulfate. In general, the ground 
water becomes more mineralized as depth increases. The quality of ground water associated with carbonate rocks is commonly impaired by hydrogen sulfide, which can be recognized by its disagreeable odor.

Province 11, in the eastern Lower Peninsula, is characterized by moderately thick, low-yielding, glacial lacustrine clay that overlies low yielding Devonian and Mississippian shale and sandstone containing highly mineralized water. Ground-water resources of the province are considered extremely poor in terms of yield and quality. The province relies heavily on surface-water supplies, mostly from Lakes Huron and Erie. Water quality in all inland rivers and streams in the province is generally considered poor, and there are sections of degraded quality at the mouths of all rivers. Most rivers receive industrial and sewage effluent that contribute large amounts of dissolved solids and nutrients and reduce dissolved-oxygen concentration. Water quality in lacustrine deposits and in the Devonian and Mississippian bedrock is generally poor. The water contains high concentrations of iron and dissolved solids, and it is very hard. High concentrations of sodium and chloride are common.

Province 12, the east-central Lower Peninsula, is characterized by low yielding, glacial-lake deposits of variable thickness that overlie sedimentary rocks of Mississippian and Pennsylvanian age. The sandstones contain highly mineralized water. Fresh ground water is difficult to obtain; therefore, most communities rely on surface water from Lake Huron for their water-supply needs. Water quality in most of the Saginaw River system is considered poor, and many reaches have been degraded by urban and industrial runoff and discharge. Ground-water quality is extremely poor and is not suitable for most uses without treatment. Throughout most of the province, the Mississippian and Pennsylvanian bedrock contains saline water. 


\section{SELECTED REFERENCES}

Annable, M.D., Kubitz, J.A., and Ryan, P.M., 1987, An introduction to Michigan's water resources: Michigan State University, Institute of Water Research, 64 p.

Baltusis, M.A., Quigley, M.F., Mandle, R.J., 1991, Municipal ground-water development and withdrawals in the Central Lower Peninsula of Michigan: U.S. Geological Survey Water-Resources Investigations Report 91-215, 89 p.

Bedell, D.J., 1982, Municipal water withdrawals in Michigan: Michigan Department of Natural Resources, Water Management Division, 43 p.

Cummings, T.R., 1989, Natural ground-water quality in Michigan, 1974-87: U.S. Geological Survey Open-File Report 89-259, 50 p.

Cummings, T.R., Twenter, F.R., and Holtschlag, D.J., 1984, Hydrology and 1 and use in Van Buren County, Michigan: U.S. Geological Survey WaterResources Investigations Report 84-4112, $124 \mathrm{p}$.

Dannemiller, G.T., and Baltusis, M.A., 1990, Physical and chemical data for ground water in the Michigan Basin, 1986-89: U.S. Geological Survey Open-File Report 90-368, 155 p.

Deutsch, Morris, Burt, E.M., and Vanlier, K.E., 1959, Summary of ground-water investigations in the Holland area, Michigan: Michigan Geological Survey Division Progress Report 20, 78 p.

Doonan, C.J., and Byerlay, J.R., 1973, Ground water and geology of Baraga County, Michigan: Michigan Geological Survey Water Investigation 11, 26 p.

Doonan, C.J., and Hendrickson, G.E., 1967, Ground water in Iron County, Michigan: Michigan Geological Survey Water Investigation 7,61 p.

---- 1968, Ground water in Gogebic County, Michigan: Michigan Geological Survey Water Investigation $8,22 \mathrm{p}$.

---- 1969, Ground water in Ontonagon County, Michigan: Michigan Geological Survey Water Investigation 9, $29 \mathrm{p}$.

Doonan, C.J., Hendrickson, G.E., and Byerlay, J.R., 1970, Ground water and geology of Keweenaw Peninsula, Michigan: Michigan Geological Survey Water Investigation $10,41 \mathrm{p}$.

Dumouchelle, D.H., Cummings, T.R., and Klepper, G.R., 1989, Michigan groundwater quality, in U.S. Geological Survey, National Water Sumary 1986-hydrologic events and ground-water quality: U.S. Geological Survey Water-Supply Paper 2325, p. 305-312.

Durfor, C.N., and Becker, Edith, 1964, Public water supplies of the 100 largest cities in the United States, 1962: U.S. Geological Survey Water-Supply Paper 1812, 364 p. 
Farrand, W.R., and Bel1, D.L., 1984, Quaternary geology of Michigan with surface water drainage divides: Michigan Department of Natural Resources Geological Survey Division, scale 1:500,000, 2 sheets.

Ferris, J.G., Burt, E.M., Strame1, G.J., and Crosthwaite, E.G., 1954, Ground water resources of southeastern Oakland County, Michigan: Michigan Geological Survey Progress Report 16, 158 p.

Fleck, W.B., and McDonald, M.G., 1978, Three-dimensional finite-difference model of ground-water system underlying the Muskegon County wastewater disposal system, Michigan: U.S. Geological Survey Journal of Research, v. 6 , no. 3 , p. 307-318.

Gillespie, J.L., and Dumouchelle, D.H., 1989, Ground-water flow and quality near the upper Great Lakes connecting channels, Michigan: U.S. Geological Survey Water-Resources Investigations Report 88-4232, 82 p.

Gingrich, R.W., 1969, Northwest Michigan Resource Conservation and Development Project Steering Committee, Northwest Michigan Resource Conservation and Development Project Plan: 105 p.

Grannemann, N.G., 1978, Water resources of the Marquette Iron Range area, Marquette County, Michigan: U.S. Geological Survey Open-File Report 79-1339, 77 p.

-- 1984, Hydrogeology and effects of the tailing basins on the hydrology of Sand Plains, Marquette County, Michigan: U.S. Geological Survey WaterResources Investigations Report 84-4114, $98 \mathrm{p}$.

Grannemann, N.G., Twenter, F.R., 1985, Geohydrology and ground-water flow at Verona well field, Battle Creek, Michigan: U.S. Geological Survey WaterResources Investigations Report 85-4056, 54 p.

Grannemann, N.G., Twenter, F.R., Huffman, G.C., and Cummings, T.R., 1985, Michigan ground-water resources, in U.S. Geological Survey, National Water Summary 1984--Hydrologic events, selected water-quality trends, and ground-water resources: U.S. Geologic Survey Water-Supply Paper 2275, p. 255-260.

Great Lakes Basin Commission, 1975, Great Lakes basin framework study-appendix 7, water quality: Water quality work group, 228 p.

Hamblin, W.K., 1958, The Cambrian sandstones of northern Michigan: Michigan Geological Survey Publication 51, 146 p.

Hendrickson, G.E., and Doonan, C.J., 1966, Ground-water resources of Dickinson County, Michigan: Michigan Geological Survey Water Investigation $5,49 \mathrm{p}$.

---- 1970, Reconnaissance of the Pigeon River, a cold-water river in the north-central part of Michigan's southern Peninsula: U.S. Geological Survey Hydrologic Investigation Atlas HA-333, 2 sheets. 
--- 1971a, Reconnaissance of the Pere Marquette River, a cold-water river in the central part of Michigan's southern Peninsula: U.S. Geological Survey Hydrologic Investigations Atlas HA-384, scale 1:62,500, 2 sheets.

--- 1971b, Reconnaissance of the Sturgeon River, a cold-water river in the north-central part of Michigan's southern Peninsula: U.S. Geological Survey Hydrologic Investigations Atlas HA-353, 2 sheets.

--- 1974, Reconnaissance of the upper Au Sable River, a cold-water river in the north-central part of Michigan's southern Peninsula: U.S. Geological Survey Hydrologic Investigations Atlas HA-527, 1 sheet.

Huffman, G.C., 1978, Ground-water data for Michigan--1977: U.S. Geological Survey Open-File Report 79-332, 75 p.

---- 1979, Ground-water data for Michigan--1978: U.S. Geological Survey Open-File Report 80-002, 61 p.

---- 1980, Ground-water data for Michigan--1979: U.S. Geological Survey Open-File Report 80-1212, 56 p.

--- 1981, Ground-water data for Michigan--1980: U.S. Geological Survey Open-File Report 81-811, 57 p.

---- 1982, Ground-water data for Michigan--1981: U.S. Geological Survey Open-File Report 82-754, 55 p.

1983, Ground-water data for Michigan-1982: U.S. Geological Survey Open-File Report 83-753, 54 p.

--- 1984, Ground-water data for Michigan--1983: U.S. Geological Survey Open-File Report 84-623, 47 p.

--- 1985, Ground-water data for Michigan--1984: U.S. Geological Survey Open-File Report 85-420, 50 p.

--- 1986, Ground-water data for Michigan--1985: U.S. Geological Survey Open-File Report 86-417, 50 p.

---- 1988, Ground-water data for Michigan--1986: U.S. Geological Survey Open-File Report 88-87, 52 p.

Huffman, G.C., and Whited, C.R., 1988, Ground-water data for Michigan--1987: U.S. Geological Survey Open-File Report 88-704, 56 p.

Humphrys, C.R., and Green, R.F., 1962, Michigan lake inventory: Michigan State University Department of Resources Development Bullet in 39, p. $39 \mathrm{~A}-39 \mathrm{C}$.

Knutilla, R.L., 1969, Water resources of the Pine River basin, southeastern Michigan: U.S. Geological Survey Hydrological Investigations Atlas HA-327, 1 sheet. 
--- 1970, Water resources of the Black River basin, southeastern Michigan: U.S. Geological Survey Hydrologic Investigations Atlas HA-338, scale $1: 250,000,3$ sheets.

Knutilla, R.L., and Allen, W.B., 1975, Water resources of the River Raisin basin, southeastern Michigan: U.S. Geological Survey Hydrologic Investigations Atlas HA-520, scale 1:125,000, 2 sheet.

Mandle, R.J., and West john, D.B., 1988, Geohydrologic framework and groundwater flow in the Michigan Basin, in Swain, L.A., and Johnson, A.I., eds., Regional aquifer systems of the United States--aquifers of the midwestern area: American Water Resources Association Monograph Series 13, p. 83-109.

Martin, H.M., 1955, Map of the surface formations of the southern Peninsula of Michigan: Michigan Geological Survey Division, scale 1,500,000.

--- 1957a, Map of the surface formations of the northern Peninsula of Michigan: Michigan Geological Survey Division, scale 1:500,000.

--- 1957b, Outline of the geologic history of Hillsdale County: Michigan Geological Survey Division, 11 p.

McDonald, M.G., 1981, Hydraulic characteristics of an underdrained irrigation circle, Muskegon County wastewater disposal system, Michigan: U.S. Geological Survey Water-Supply Paper 2081, 14 p.

McDonald, M.G., and Fleck, W.B., 1978, Model analysis of the impact on groundwater conditions of the Muskegon County wastewater disposal system, Michigan: U.S. Geological Survey Open-File Report 78-99, 63 p.

McGuinness, C.L., Poindexter, O.F., and Otton, E.G., 1949, Ground-water supplies of the Ypsilanti area, Michigan: U.S. Geological Survey WaterSupply Paper 1078, 103 p.

Michigan Water Resources Commission, 1960, Water resource conditions and uses in the Tittabawassee River basin: Michigan Department of Natural Resources, $117 \mathrm{p}$.

-.- 1963, Water resource conditions and uses in the Shiawassee River basin: Michigan Department of Natural Resources, 113 p.

1964, Water resource conditions and uses in the Paw Paw River basin: Michigan Department of Natural Resources, 56 p.

---- 1968a, The water resources of the Upper Peninsula drainage area--an overview of region water uses: Michigan Department of Natural Resources, 164 p.

- 1968b, The water resources of south-eastern Michigan--an overview of region water uses: Michigan Department of Natural Resources, 162 p. 
--- 1968c, The water resources of the northern Lake Michigan and Lake Huron drainage area Lower Peninsula-- an overview of region water uses: Michigan Department of Natural Resources, 189 p.

---- 1968d, The water resources of the lower Lake Michigan drainage basin-an overview of region water use: Michigan Department of Natural Resources, $172 \mathrm{p}$.

---- 1968e, The water resources of the lower Lake Huron drainage basin--an overview of region water uses: Michigan Department of Natural Resources, $189 \mathrm{p}$.

Miller, J.B., and Twenter, F.R., 1986, Michigan surface-water resources, in U.S. Geological Survey, National Water Summary 1985--hydrologic events and surface-water resources: U.S. Geological Survey Water-Supply Paper 2300, p. 277-284.

Milstein, R.L., 1987, Bedrock geology of southern Michigan: Michigan Geological Survey, scale 1:500,000.

Mozola, A.J., 1970, Geology for environmental planning in Monroe County, Michigan: Michigan Geological Survey Report of Investigation 13, 34 p.

National Oceanic and Atmospheric Administration, 1986, Climatological data-Michigan annual summary: Asheville, N.C., National Climatic Center, v. 101 , no. 13,26 p.

Newcombe, R.B., 1932, Oil and gas fields of Michigan--a discussion of depositional and structural features of the Michigan basin: Michigan Geological Survey Publication 38, Geological Series 32, 293 p.

Nowl in, J.0., 1973, Water resources of the Clinton River basin, southeastern Michigan: U.S. Geological Survey Hydrological Investigations Atlas HA-469, 2 sheets.

Passero, R.N., Straw, W.T., and Schmaltz, L.J., 1981, Hydrogeologic atlas of Michigan--glacial drift thickness, plate 15: Western Michigan University, College of Arts and Sciences, Department of Geology, scale $1: 500,000$.

Reed, R.C., and Daniels, Jennifer, 1987, Bedrock geology of northern Michigan: Michigan Geological Survey, scale 1:500,000.

Rheaume, S.J., 1990, Geohydrology and water quality of Kalamazoo County, Michigan: U.S. Geological Survey Water-Resources Investigations Report 90-4028, $102 \mathrm{p}$.

Sinclair, W.C., 1959, Reconnaissance of the ground-water resources of Schoolcraft County, Michigan: Michigan Geological Survey Progress Report 22, 76 p.

--- 1960, Reconnaissance of the ground-water resources of Delta County, Michigan: Michigan Geological Survey Progress Report 24, 93 p. 
Stark, J.R., Cummings, T.R., and Twenter, F.R., 1983, Ground-water contamination at Wurtsmith Air Force Base, Michigan: U.S. Geological Survey Water-Resources Investigations Report 83-4002, 93 p.

Stuart, W.T., Theis, C.V., and Stanley, G.M., 1948, Ground-water problems in the Iron River district, Michigan: Michigan Geological Survey Technical Report 2, 59 p.

Sweat, M.J., and Van Til, R.L., 1990, Michigan water supply and use, in U.S. Geological Survey, National Water Summary 1987--hydrologic events and water supply and use: U.S. Geological Survey Water-Supply Paper 2350, p. 305-312.

Twenter, F.R., 1966a, General availability and quality of ground water in the bedrock deposits in Michigan: State Resources Planning Division, Michigan Department of Commerce and Michigan Water Resources Commission, scale $1: 1,000,000$.

---- 1966b, General availability of ground water in the glacial deposits in Michigan: State Resource Planning Division, Michigan Department of Commerce and Michigan Water Resources Commission, scale 1:1,000,000.

--- 1978, Water-resources investigations in Michigan, 1978: U.S. Geological Survey, 6 p.

1981, Geology and hydrology for environmental planning in Marquette County, Michigan: U.S. Geological Survey Water-Resources Investigations Report 80-90, 56 p.

Twenter, F.R., Knutilla, R.L., and Cummings, T.R., 1975, Water resources of basins for minor streams draining into St. Clair River, Lake St. Clair, Detroit River, and Lake Erie, southeastern Michigan: U.S. Geological Survey Hydrologic Investigations Atlas HA-546, scale 1:250,000, 3 sheets.

U.S. Bureau of Census, 1982, 1980 Census of population, number of inhabitants-Michigan: U.S. Bureau of Census, v. 1, chap. A, part 24.

U.S. Geological Survey, 1974, Hydrologic unit map--1974, State of Michigan: scale 1:500,000, 2 sheets.

Vanlier, K.E., 1959, Reconnaissance of the ground-water resources of Luce County, Michigan: Michigan Geological Survey Progress Report 21, 76 p.

1963a, Reconnaissance of the ground-water resources in Alger County, Michigan: Michigan Geological Survey Water Investigation 1, 55 p.

--- 1963b, Ground water in Menominee County: Michigan Geological Survey Water Investigation $2,42 \mathrm{p}$.

--- 1966, Ground-water resources of the Battle Creek area, Michigan: Michigan Geological Survey Division Water Investigation 4, 52 p. 
U.S. Environmental Protection Agency, 1986a, Maximum contaminant levels (subpart B of part 141, National interim primary drinking-water regulations): U.S. Code of Federal Regulation, Title 40, Parts 100 to 149, revised as of July 1, 1986, p. 524-528, 567-568.

--- 1986b, Secondary maximum contaminant levels (section 143.3 of part 143, National secondary drinking-water regulations): U.S. Code of Federal Regulations, Title 40, Parts 100 to 149, revised as of July 1, 1986, p. 587-590.

\section{U.S. Geological Survey Water-Data Reports}

\begin{tabular}{llll} 
Year & Report Number & Year & Report Number \\
\cline { 3 - 3 } 1975 & MI-75-1 & & \\
1976 & MI-76-1 & 1982 & MI-82-1 \\
1977 & MI-77-1 & 1983 & MI-83-1 \\
1978 & MI-78-1 & 1984 & MI-84-1 \\
1979 & MI-79-1 & 1985 & MI-85-1 \\
1980 & MI-80-1 & 1986 & MI-86-1 \\
1981 & MI-81-1 & 1987 & MI-87-1
\end{tabular}

Vanlier, K.E., and Deutsch, Morris, 1958a, Reconnaissance of the ground-water resources of Chippewa County, Michigan: Michigan Geological Survey Progress Report 17, 56 p.

-- 1958b, Reconnaissance of the ground-water resources of Mackinac County, Michigan: Michigan Geological Survey Progress Report 19, 82 p.

Vanlier, K.E., Wood, W.W., and Brunett, J.0., 1973, Water-supply development and management alternatives for $\mathrm{Clinton,} \mathrm{Eaton,} \mathrm{and} \mathrm{Ingham} \mathrm{Counties,}$ Michigan: U.S. Geological Survey Water-Supply Paper 1969, 111 p.

Westjohn, D.B., 1988, Application of geophysics in the delineation of the freshwater/saline-water interface in the Michigan Basin, in Swain, L.A., and Johnson, A.I., eds., Regional aquifer systems of the United States-aquifers of the midwestern area: American Water Resources Association Monograph Series 13, p. 111-133.

Wiitala, S.W., Vanlier, K.E., and Krieger, R.A., 1963, Water resources of the Flint area, Michigan: U.S. Geological Survey Water-Supply Paper 1499-E, 86 p.

Wood, W.W., 1970, Chemical quality of Michigan streams: U.S. Geological Survey Circular 634, 21 p. 
Aquifer. A formation, group of formations, or part of a formation that contains sufficient saturated permeable material to yield significant quantities of water to wells and springs.

Base flow. The discharge entering stream channels as inflow from ground water or other delayed sources; sustained or fair-weather flow of streams.

Bedrock. Consolidated rock that underlies soil or other unconsolidated material.

Concentration. The weight of a dissolved constituent or of sediment per unit volume of water, expressed in milligrams per liter (mg/L) or micrograms per liter $(\mu g / L)$.

Cubic feet per second. A unit expressing rate of discharge. One cubic foot per second is equal to the discharge of a stream 1 foot wide and 1 foot deep flowing at an average velocity of 1 foot per second.

Discharge. The rate of flow of a stream; reported in cubic feet per second $\left(\mathrm{ft}^{3} / \mathrm{s}\right)$.

Dissolved solids. Substances present in water that are in true chemical solution.

Divide. A line of separation between drainage systems. A topographic divide delineates the land from which a stream gathers its water; a ground-water divide is a line on a potentiometric or water-table surface on each side of which the potentiometric surface slopes downward away from the line.

Elevation. Vertical distance of a point or line above or below the National Geodetic Vertical Datum of 1929. The National Geodetic Vertical Datum of 1929 (NGVD of 1929) is a geodetic datum derived from a general adjustment of the first-order level nets of the United States and Canada, formerly called "Sea Level Datum of 1929." In this report, all elevations are above NGVD of 1929.

Evapotranspiration. Water withdrawn from a land area by direct evaporation from water surfaces and moist soil and by plant transpiration, no attempt being made to distinguish between the two.

Ground water. Water that is in the saturated zone from which wells, springs, and ground-water inflow to streams are supplied.

Ground-water runoff. Ground water that has discharged into stream channels by seepage from saturated earth materials.

Hydraulic conductivity. The volume of water at the prevailing kinematic viscosity that will move in unit time under a unit hydraulic gradient through a unit area measured at right angles to the direction of flow. In general terms, hydraulic conductivity is the ability of a porous medium to transmit water. 
Permeability. A measure of the relative ease with which a porous medium can transmit a liquid under a potential gradient. It is a property of the medium alone, and is independent of the nature of the fluid and of the force field.

Recharge. The process by which water is infiltrated and is added to the zone of saturation. It is also the quantity of water added to the zone of saturation.

Runoff. That part of precipitation that appears in streams; the water draining from an area. When expressed in inches, it is the depth to which an area would be covered if all the water draining from it in a given period were uniformly distributed on its surface.

Specific conductance. A measure of the ability of water to conduct an electric current, expressed in microsiemens per centimeter $(\mu \mathrm{S} / \mathrm{cm})$ at 25 degrees Celsius. Because the specific conductance is related to amount and type of dissolved material, it is used for approximating the dissolved-solids concentration of water. For most natural waters the ratio of dissolved-solids concentration (in milligrams per liter) to specific conductance (in microsiemens) is in the range 0.5 to 0.8 .

Transmissivity. The rate at which water of the prevailing kinematic viscosity is transmitted through a unit width of the aquifer under a unit hydraulic gradient.

Water table. That surface in an unconfined water body at which the pressure is atmospheric. It is defined by levels at which water stands in wells. No water table exists where the upper surface of the water body is confined by low-permeability materials. 
DATA TABLES 
Table 1.-- Selected streamflow characteristics of major rivers in Michigan

[Gaging station: Period of analysis is for the water years used to compute average discharge and may differ from that used to compute other streamflow characteristics. Streamflow characteristics: The 7-day, 10-year low flow is a discharge statistic; the lowest mean discharge during 7 consecutive days of a year will be equal to or less than this value, on the average, once every 10 years. The average discharge is the arithmetic average discharge during the period of analysis. The 100-year flood is that flow that has a 1-percent chance of being equaled or exceeded in a given year. The 95-percent flow duration is a discharge statistic interpolated from a duration table; during 95 percent of the period of analysis, mean discharge will be equal to or greater than this value. Abbreviations: $\mathbf{m i}^{2}$, square miles; $\mathrm{ft}^{3} / \mathrm{s}$, cubic feet per second; --, no analysis made. Source: U.S. Geological Survey Water-Data Report MI-88-1]

\begin{tabular}{|c|c|c|c|c|c|c|c|}
\hline \multirow[b]{3}{*}{$\begin{array}{c}\text { Site } \\
\text { number }\end{array}$} & \multirow{2}{*}{\multicolumn{3}{|c|}{ Gaging station }} & \multicolumn{4}{|c|}{ Streamflow characteristics } \\
\hline & & & & \multirow{2}{*}{$\begin{array}{c}\text { 7-day } \\
\text { 10-year } \\
\text { low flow } \\
\text { discharge } \\
\text { (ft } 3 / \mathrm{s} \text { ) }\end{array}$} & \multirow[b]{2}{*}{$\begin{array}{c}\text { Average } \\
\text { discharge } \\
(\mathrm{ft} / \mathrm{s})\end{array}$} & \multirow[b]{2}{*}{$\begin{array}{l}\text { 100-year } \\
\text { flood } \\
\text { discharge } \\
\text { (ft } 3 / \mathrm{s})\end{array}$} & \multirow{2}{*}{$\begin{array}{l}\text { 95-percent } \\
\text { flow } \\
\text { duration } \\
\text { discharge } \\
(\mathrm{ft} / \mathrm{s})\end{array}$} \\
\hline & $\begin{array}{l}\text { Name and } \\
\text { USGS number }\end{array}$ & $\begin{array}{l}\text { Drainage } \\
\quad \text { area } \\
\left(m i^{2}\right)\end{array}$ & $\begin{array}{l}\text { Period } \\
\text { of } \\
\text { analysis }\end{array}$ & & & & \\
\hline 1 & $\begin{array}{l}\text { Ontonagon River } \\
\text { near Rockland } \\
(04040000)\end{array}$ & 1,340 & $1943-88$ & 313 & 1,420 & 27,000 & 435 \\
\hline 2 & $\begin{array}{l}\text { Sturgeon River } \\
\text { near Alston } \\
(04041500)\end{array}$ & 346 & $\begin{array}{l}1934-40 \\
1944-88\end{array}$ & - & 421 & 7,110 & 75.6 \\
\hline 4 & $\begin{array}{l}\text { Tahquamenon River } \\
\text { near Paradise } \\
(04045500)\end{array}$ & 790 & $1954-88$ & 199 & 927 & 7,990 & 265 \\
\hline 6 & $\begin{array}{l}\text { Manistique River } \\
\text { near Manistique } \\
(04056500)\end{array}$ & 1,100 & $1939-88$ & 366 & 1,430 & 17,000 & 480 \\
\hline 8 & $\begin{array}{l}\text { Escanaba River } \\
\text { at Corneli } \\
(04059000)\end{array}$ & 870 & $\begin{array}{l}1904-12 \\
1951-88\end{array}$ & 170 & 883 & 13,200 & 213 \\
\hline 10 & $\begin{array}{c}\text { Menominee River } \\
\text { near Florence } \\
(04063000)\end{array}$ & 1,780 & $1915-88$ & 539 & 1,820 & 19,200 & 733 \\
\hline 12 & $\begin{array}{l}\text { St. Joseph River } \\
\text { at Niles } \\
(04101500)\end{array}$ & 3,666 & $1931-88$ & 956 & 3,300 & 20,900 & 1,210 \\
\hline 13 & $\begin{array}{l}\text { Kal amazoo River } \\
\text { at Comstock } \\
(04106000)\end{array}$ & 1,010 & $\begin{array}{l}1934-79 \\
1986-88\end{array}$ & 264 & 862 & 7,180 & 337 \\
\hline 14 & $\begin{array}{c}\text { Kalamazoo River } \\
\text { near Fennville } \\
(04108500)\end{array}$ & 1,600 & $\begin{array}{l}1930-36 \\
1938-88\end{array}$ & 345 & 1,440 & 12,500 & 588 \\
\hline 15 & $\begin{array}{l}\text { Grand River } \\
\text { at Lansing } \\
(04113000)\end{array}$ & 1,230 & $\begin{array}{l}1902-06 \\
1935-88\end{array}$ & 81.3 & 840 & 18,600 & 133 \\
\hline 16 & $\begin{array}{l}\text { Grand River } \\
\text { at Grand Rapids } \\
(04119000)\end{array}$ & 4,900 & $\begin{array}{l}1902-05 \\
1931-88\end{array}$ & 730 & 3,630 & 52,700 & 997 \\
\hline 18 & $\begin{array}{l}\text { Muskegon River } \\
\text { at Newaygo } \\
(04122000)\end{array}$ & 2,350 & $\begin{array}{l}1910-14 \\
1917-19 \\
1931-88\end{array}$ & 678 & 2,000 & 16,700 & 871 \\
\hline
\end{tabular}


Table 1.--Selected streamflow characteristics of major rivers in Michigan--Cont inued

\begin{tabular}{|c|c|c|c|c|c|c|c|}
\hline \multirow[b]{3}{*}{$\begin{array}{c}\text { site } \\
\text { number }\end{array}$} & \multirow{2}{*}{\multicolumn{3}{|c|}{ Gaging station }} & \multicolumn{4}{|c|}{ Streamflow characteristics } \\
\hline & & & & \multirow{2}{*}{$\begin{array}{c}\text { 7-day } \\
\text { lo-year } \\
\text { low low } \\
\text { discharge } \\
\text { (ft } / \mathrm{s})\end{array}$} & \multirow[b]{2}{*}{$\begin{array}{l}\text { Average } \\
\text { discharge } \\
\text { (ft: } / \mathrm{s})\end{array}$} & \multirow[b]{2}{*}{$\begin{array}{c}\text { 100-year } \\
\text { flood } \\
\text { discharge } \\
\text { (ft } / \mathrm{s} \text { ) }\end{array}$} & \multirow{2}{*}{$\begin{array}{c}\text { 95-percent } \\
\text { flow } \\
\text { duration } \\
\text { discharge } \\
\left(\mathrm{ft}^{3} / \mathrm{s}\right)\end{array}$} \\
\hline & $\begin{array}{l}\text { Name and } \\
\text { USGS number }\end{array}$ & $\begin{array}{l}\text { Drainage } \\
\text { area } \\
\left(\mathrm{mi}^{2}\right)\end{array}$ & $\begin{array}{l}\text { Period } \\
\text { of } \\
\text { analysis }\end{array}$ & & & & \\
\hline 20 & $\begin{array}{l}\text { Manistee River } \\
\text { near Manistee } \\
(04126000)\end{array}$ & 1,677 & $1952-88$ & 1,213 & 2,040 & 8,600 & 1,320 \\
\hline 22 & $\begin{array}{l}\text { Cheboygan River } \\
\text { near Cheboygan } \\
(0413000)\end{array}$ & 865 & $1943-82$ & 238 & 822 & -- & 409 \\
\hline 24 & $\begin{array}{l}\text { Thunder Bay River } \\
\text { near Alpena } \\
(04135000)\end{array}$ & 1,238 & $\begin{array}{l}1902-08 \\
1980-88\end{array}$ & 94.6 & 913 & -- & 160 \\
\hline 25 & $\begin{array}{c}\text { Au Sable River } \\
\text { at Mio } \\
(04136500)\end{array}$ & 1,100 & $1953-88$ & 552 & 997 & 4,250 & 662 \\
\hline 27 & $\begin{array}{l}\text { Rifle River } \\
\text { near Sterling } \\
(04142000)\end{array}$ & 320 & $1937-88$ & 120 & 313 & 4,840 & 140 \\
\hline 28 & $\begin{array}{l}\text { Shiawassee River } \\
\text { at OwOSSO } \\
(04144500)\end{array}$ & 538 & $1931-88$ & 55.4 & 338 & 9,330 & 46.3 \\
\hline 29 & $\begin{array}{l}\text { Tittabawassee River } \\
\text { at Midland } \\
(04156000)\end{array}$ & 2,400 & $1937-88$ & 190 & 1,730 & 45,900 & 296 \\
\hline 31 & $\begin{array}{c}\text { Saginaw River } \\
\text { at Saginaw } \\
(04157000)\end{array}$ & 6,060 & $\begin{array}{l}\text { Inter- } \\
\text { mittent, } \\
\text { 1904-88 }\end{array}$ & -- & -- & 73,500 & -- \\
\hline 34 & $\begin{array}{l}\text { Clinton River } \\
\text { at Mount Clemens } \\
(04165500)\end{array}$ & 734 & $1935-88$ & 63.0 & 542 & 22,800 & 93.0 \\
\hline 37 & $\begin{array}{l}\text { Huron River } \\
\text { at Ann Arbor } \\
(04174500)\end{array}$ & 729 & $1905-88$ & 44.5 & 459 & 5,800 & 86.8 \\
\hline 38 & $\begin{array}{l}\text { River Raisin } \\
\text { near Monroe } \\
(04176500)\end{array}$ & 1,042 & $1938-88$ & 43.2 & 727 & 17,600 & 74.8 \\
\hline
\end{tabular}

1 Locations of these sites are shown on figure 11. 
Table 2.--Physical and chemical characteristics of streams during 10w flow, $\underline{1974-89}$

[Analyses by U.S. Geological Survey. Site locations shown on figure 11. $<$, less than; --, no analysis made; $\mathrm{ft}^{3} / \mathrm{s}$, cubic feet per second; $\mu \mathrm{S} / \mathrm{cm}$, microsiemens per centimeter at 25 degrees Celsius; ${ }^{\circ} \mathrm{C}$, degree Celsius; mg/L, milligrams per liter; $\mu g / L$, micrograms per 1 iter]

\begin{tabular}{|c|c|c|c|c|c|c|c|}
\hline $\begin{array}{l}\text { Site } \\
\text { number }\end{array}$ & $\begin{array}{l}\text { Station number } \\
\text { and name }\end{array}$ & $\begin{array}{l}\text { Date } \\
\text { of } \\
\text { sample }\end{array}$ & Time & $\begin{array}{l}\text { stream- } \\
\text { flow } \\
\text { instan- } \\
\text { taneous } \\
\left(f t^{3} / 8\right)\end{array}$ & $\begin{array}{l}\text { spe- } \\
\text { cific } \\
\text { con- } \\
\text { duct- } \\
\text { ance } \\
(\mu 8 / \mathrm{cm})\end{array}$ & $\begin{array}{l}\text { Temper- } \\
\text { ature, } \\
\text { water } \\
\left({ }^{\circ} \mathrm{C}\right)\end{array}$ & $\begin{array}{l}\text { Sedi- } \\
\text { ment, } \\
\text { sus- } \\
\text { pended } \\
\text { (mg/L) }\end{array}$ \\
\hline 1 & $\begin{array}{l}04040000 \\
\text { Ontonagon River near Rockland }\end{array}$ & $09-28-76$ & 0830 & 236 & 171 & 8.0 & 12 \\
\hline 3 & $\begin{array}{l}04043004 \\
\text { Sturgeon River near Chassell }\end{array}$ & $02-23-78$ & 1100 & 212 & 166 & 0 & 2 \\
\hline 4 & $\begin{array}{l}04045500 \\
\text { Tahguamenon River near Paradise }\end{array}$ & $09-01-76$ & 1400 & 214 & 190 & 18.0 & 3 \\
\hline 5 & $\begin{array}{l}04045580 \\
\text { St. Marys River above Sault Ste. } \\
\text { Marie }\end{array}$ & $11-05-81$ & 0935 & 44,200 & 98 & 10.0 & -- \\
\hline 7 & $\begin{array}{l}04057004 \\
\text { Manistique River above Manistique }\end{array}$ & $06-16-77$ & 1145 & 400 & 182 & 19.0 & 3 \\
\hline 8 & $\begin{array}{l}04059000 \\
\text { Escanaba River at Cornell }\end{array}$ & $02-14-77$ & 1100 & 121 & 227 & 0 & 7 \\
\hline 9 & $\begin{array}{l}04059500 \\
\text { Ford River near Hyde }\end{array}$ & $09-16-76$ & 1230 & 24 & 322 & 16.0 & 0 \\
\hline 11 & $\begin{array}{l}04067500 \\
\text { Nemominee River near MCAllister, WI }\end{array}$ & $09-16-81$ & 1415 & 1,690 & 220 & 17.5 & 1 \\
\hline 12 & $\begin{array}{l}04101500 \\
\text { St. Joseph River at Niles }\end{array}$ & $12-15-81$ & 1345 & 818 & 562 & 2.0 & 11 \\
\hline 13 & $\begin{array}{l}04106000 \\
\text { Kalamazoo River at Comstock }\end{array}$ & $07-31-86$ & 1120 & 778 & 585 & 29.0 & 8 \\
\hline 14 & $\begin{array}{l}04108500 \\
\text { Kalamazoo River near Fennville }\end{array}$ & $07-28-88$ & 1500 & 650 & 595 & 28.5 & 17 \\
\hline 17 & $\begin{array}{l}04119300 \\
\text { Grand River at Eastmanville }\end{array}$ & $09-17-79$ & 1230 & 1,180 & 620 & 19.5 & 20 \\
\hline 19 & $\begin{array}{l}04122030 \\
\text { Muskegon River near Bridgeton }\end{array}$ & $08-15-78$ & 1100 & 810 & 350 & 23.0 & 8 \\
\hline 21 & $\begin{array}{l}04126520 \\
\text { Manistee River at Manistee }\end{array}$ & $01-12-78$ & 1345 & 1,000 & 395 & 0 & 3 \\
\hline
\end{tabular}


Table 2.--Physical and chemical characteristics of streams during low flow, 1974-89--Continued

\begin{tabular}{|c|c|c|c|c|c|c|c|}
\hline $\begin{array}{c}\text { site } \\
\text { number }\end{array}$ & $\begin{array}{l}\text { Station number } \\
\text { and name }\end{array}$ & $\begin{array}{c}\text { Date } \\
\text { of } \\
\text { sample }\end{array}$ & Time & $\begin{array}{l}\text { stream- } \\
\text { Elow } \\
\text { lnstan- } \\
\text { taneous } \\
(\text { ft } / \mathrm{s})\end{array}$ & $\begin{array}{l}\text { spe- } \\
\text { cific } \\
\text { con- } \\
\text { duct- } \\
\text { ance } \\
(\mu 8 / \mathrm{cm})\end{array}$ & $\begin{array}{l}\text { Temper- } \\
\text { ature, } \\
\text { water } \\
\left({ }^{\circ} \mathrm{C}\right)\end{array}$ & $\begin{array}{l}\text { Sedl- } \\
\text { ment, } \\
\text { sus- } \\
\text { pended } \\
(\mathrm{mg} / \mathrm{L})\end{array}$ \\
\hline 23 & $\begin{array}{l}04132052 \\
\text { Choboygan River at Chaboygan }\end{array}$ & $08-11-77$ & 1000 & 410 & 280 & 21.5 & 1 \\
\hline 24 & $\begin{array}{l}04135000 \\
\text { Thunder Bay River near Alpena }\end{array}$ & $10-08-80$ & 0730 & 36 & 326 & 10.5 & 3 \\
\hline 26 & $\begin{array}{l}04137500 \\
\text { Au Sable Rlver near Au Sable }\end{array}$ & $07-18-78$ & 0945 & 41 & 300 & 23.0 & 3 \\
\hline 27 & $\begin{array}{l}04142000 \\
\text { Rifle River near sterling }\end{array}$ & $01-08-80$ & 1230 & 80 & 480 & 0 & 14 \\
\hline 30 & $\begin{array}{l}04156100 \\
\text { TIttabawassee River near Midland }\end{array}$ & $08-04-87$ & 1330 & 230 & 661 & 28.5 & 47 \\
\hline 31 & $\begin{array}{l}04157000 \\
\text { Saglnaw River at Saginaw }\end{array}$ & $06-10-81$ & 1430 & $-1,370$ & 535 & 21.5 & 41 \\
\hline 32 & $\begin{array}{l}04159010 \\
\text { Plgeon River near Caseville }\end{array}$ & $09-27-79$ & 0800 & 0.0 & - & - & - \\
\hline 33 & $\begin{array}{l}04159130 \\
\text { St. Clalr River at Port Huron }\end{array}$ & $02-05-79$ & 1530 & 138,000 & 210 & 0 & - \\
\hline 34 & $\begin{array}{l}04165500 \\
\text { Clinton River at Mount Clemens }\end{array}$ & $07-14-78$ & 1045 & 82 & 918 & 22.0 & 16 \\
\hline 35 & $\begin{array}{l}04165700 \\
\text { Detrolt River at Detroit }\end{array}$ & $01-21-81$ & 1100 & 180,000 & 215 & .5 & -- \\
\hline 36 & $\begin{array}{l}04170500 \\
\text { Huron River near New Hudson }\end{array}$ & $09-07-84$ & 1000 & 29 & 517 & 17.5 & 9 \\
\hline 38 & $\begin{array}{l}04176500 \\
\text { River Raisin near Monroe }\end{array}$ & $09-13-88$ & 1400 & 98 & 635 & 21.5 & 26 \\
\hline
\end{tabular}


Table 2.--Physical and chemical characteristics of streams during low flow, 1974-89--Cont inued

\begin{tabular}{|c|c|c|c|c|c|c|c|c|c|c|}
\hline $\begin{array}{c}\text { Site } \\
\text { number }\end{array}$ & $\begin{array}{c}\text { Date } \\
\text { of } \\
\text { sample }\end{array}$ & $\begin{array}{l}\mathrm{pH} \\
\text { (stand- } \\
\text { ard } \\
\text { unlts) }\end{array}$ & $\begin{array}{l}\text { Oxygen, } \\
\text { dis- } \\
\text { solved } \\
\text { (mg/L) }\end{array}$ & $\begin{array}{l}\text { Nitro- } \\
\text { gen, } \\
\text { ammonia, } \\
\text { dis- } \\
\text { solved } \\
\text { (mg/L } \\
\text { as N) }\end{array}$ & $\begin{array}{l}\text { uitro- } \\
\text { gen, } \\
\text { nitrite. } \\
\text { dis- } \\
\text { solved } \\
\text { (mg/L } \\
\text { as N) }\end{array}$ & $\begin{array}{l}\text { Mitro- } \\
\text { gen, } \\
\text { nitrate. } \\
\text { dis- } \\
\text { solved } \\
\text { (mg/L } \\
\text { as } \mathrm{N})\end{array}$ & $\begin{array}{l}\text { Mltro- } \\
\text { gen, Am- } \\
\text { monila + } \\
\text { organlc. } \\
\text { total } \\
\text { (mg/L } \\
\text { as N) }\end{array}$ & $\begin{array}{l}\text { Mitro- } \\
\text { gen, } \\
\text { No }_{2}+\mathrm{Ho}_{3} \text {, } \\
\text { dis- } \\
\text { solved } \\
\text { (mg/L } \\
\text { as } \mathrm{H})\end{array}$ & $\begin{array}{c}\text { Phos- } \\
\text { phorous, } \\
\text { ortho, } \\
\text { dis- } \\
\text { solved } \\
\text { (mg/L } \\
\text { as P) }\end{array}$ & $\begin{array}{l}\text { Phos- } \\
\text { phorous, } \\
\text { total } \\
\text { (mg/L } \\
\text { as P) }\end{array}$ \\
\hline 1 & $09-28-76$ & 7.9 & 10.3 & -- & - & -- & 0.13 & -- & - & 0.02 \\
\hline 3 & $02-23-78$ & 7.1 & 10.7 & -- & -- & -- & .42 & -- & - & .02 \\
\hline 4 & $09-01-76$ & 8.1 & 7.6 & -- & -- & -- & .23 & -- & -- & .05 \\
\hline 5 & $11-05-81$ & 7.8 & 12.0 & $<0.01$ & - & -- & .52 & 0.27 & $<0.01$ & $<.01$ \\
\hline 7 & $06-16-77$ & 7.8 & 8.6 & -- & -- & -- & .34 & -- & -- & $<.01$ \\
\hline 8 & $02-14-77$ & 7.7 & 11.7 & -- & - & -- & 1.5 & -- & - & .02 \\
\hline 9 & $09-16-76$ & 8.2 & 10.1 & -- & -- & -- & .25 & -- & -- & .03 \\
\hline 11 & $09-16-81$ & 8.2 & -- & .03 & -- & -- & .48 & $<.01$ & -- & .01 \\
\hline 12 & $12-15-81$ & 7.9 & 13.1 & .34 & -- & -- & .93 & 1.70 & $<.01$ & .06 \\
\hline 13 & $07-31-86$ & 8.4 & 9.9 & .06 & 0.02 & & .8 & .6 & .02 & .18 \\
\hline 14 & $07-28-88$ & 8.5 & 12.0 & .02 & .03 & 0.63 & .9 & .66 & $<.01$ & .08 \\
\hline 17 & $09-17-79$ & 8.2 & 7.6 & -- & -- & -- & 2.0 & .34 & - & .23 \\
\hline 19 & $08-15-78$ & 8.3 & 8.2 & -- & -- & -- & .58 & -- & - & .03 \\
\hline 21 & $01-12-78$ & 7.9 & -- & -- & -- & -- & - & -- & -- & .01 \\
\hline 23 & $08-11-77$ & 8.2 & 8.0 & -- & -- & -- & .37 & -- & -- & .05 \\
\hline 24 & $10-08-80$ & 8.2 & 9.8 & .01 & -- & -- & .27 & .01 & -- & .02 \\
\hline 26 & $07-18-78$ & 8.2 & -- & -- & -- & - & .22 & -- & -- & $<.01$ \\
\hline 27 & $01-08-80$ & 7.7 & 13.4 & .00 & -- & -- & .3 & .35 & -- & .02 \\
\hline 30 & $08-04-87$ & 8.3 & 9.2 & .50 & .01 & .11 & 1.6 & .12 & .01 & .08 \\
\hline 31 & $06-10-81$ & 7.9 & 7.4 & .27 & -- & -- & 1.4 & .86 & - & .17 \\
\hline 32 & $09-27-79$ & -- & -- & -- & - & -- & -- & -- & -- & -- \\
\hline 33 & $02-05-79$ & 8.2 & 13.0 & - & -- & -- & .16 & - & - & $<.01$ \\
\hline 34 & $07-14-78$ & 8.0 & 6.0 & -- & -- & -- & 1.1 & - & -- & .28 \\
\hline 35 & $01-21-81$ & 7.6 & 14.6 & .01 & -- & -- & $<.1$ & .31 & -- & $<.01$ \\
\hline 36 & $09-07-84$ & 8.5 & 7.8 & -- & -- & -- & 1.0 & -- & -- & .04 \\
\hline 38 & $09-13-88$ & 8.6 & 12.0 & $<.01$ & $<.01$ & -- & .5 & .80 & $<.01$ & .22 \\
\hline
\end{tabular}


Table 2.--Physical and chemical characteristics of streams during low flow, 1974-89-Continued

\begin{tabular}{|c|c|c|c|c|c|c|c|c|c|c|}
\hline $\begin{array}{l}\text { site } \\
\text { number }\end{array}$ & $\begin{array}{c}\text { Date } \\
\text { of } \\
\text { sample }\end{array}$ & $\begin{array}{l}\text { Hard- } \\
\text { ness } \\
\text { total } \\
(\mathrm{mg} / \mathrm{L} \\
\mathrm{as} \\
\left.\mathrm{CaCO}_{3}\right)\end{array}$ & $\begin{array}{c}\text { Alka- } \\
\text { linity, } \\
\text { field } \\
\text { (mg/L } \\
\text { as } \\
\mathrm{CaCO}_{3} \text { ) }\end{array}$ & $\begin{array}{c}\text { solids, } \\
\text { sum of } \\
\text { constl- } \\
\text { tuents, } \\
\text { dis- } \\
\text { solved } \\
\text { (mg/L) }\end{array}$ & $\begin{array}{l}\text { solids, } \\
\text { residue } \\
\text { at } 180 \\
\circ \mathrm{C}, \\
\text { dis- } \\
\text { solved } \\
\text { (mg/L) }\end{array}$ & $\begin{array}{l}\text { Calcium, } \\
\text { dis- } \\
\text { solved } \\
\text { (mg/L } \\
\text { as (a) }\end{array}$ & $\begin{array}{l}\text { Magne- } \\
\text { sium, } \\
\text { dis- } \\
\text { solved } \\
\text { (mg/L } \\
\text { as Mg) }\end{array}$ & $\begin{array}{l}\text { Sodium, } \\
\text { dis- } \\
\text { solved } \\
\text { (mg/L } \\
\text { as } \mathrm{Na} \text { ) }\end{array}$ & $\begin{array}{l}\text { Potas- } \\
\text { gium, } \\
\text { dis- } \\
\text { solved } \\
\text { (mg/L } \\
\text { as } K \text { ) }\end{array}$ & $\begin{array}{c}\text { Sulfate, } \\
\text { dis- } \\
\text { solved } \\
\text { (mg/L } \\
\text { as } \mathrm{SO}_{4} \text { ) }\end{array}$ \\
\hline 1 & $09-28-76$ & 86 & 85 & 103 & 111 & 24 & 6.3 & 2.4 & 1.0 & 5.1 \\
\hline 3 & $02-23-78$ & 78 & 78 & 97 & 115 & 22 & 5.7 & 2.8 & 1.1 & 5.6 \\
\hline 4 & $09-01-76$ & 96 & 98 & 117 & 118 & 26 & 7.5 & 2.0 & .6 & 13 \\
\hline 5 & $11-05-81$ & 43 & 47 & 56 & 52 & 13 & 2.6 & 1.3 & .5 & 5.4 \\
\hline 7 & $06-16-77$ & 89 & 72 & 109 & 123 & 26 & 5.8 & 1.3 & .6 & 24 \\
\hline 8 & $02-14-77$ & 95 & 110 & 127 & 126 & 23 & 9.2 & 6.5 & 1.2 & 9.8 \\
\hline 9 & $09-16-76$ & 180 & 184 & 193 & 197 & 36 & 21 & 1.2 & 1.0 & 16 \\
\hline 11 & $09-16-81$ & 110 & -- & 125 & 133 & 26 & 12 & 2.6 & 1.2 & 12 \\
\hline 12 & $12-15-81$ & 260 & 230 & 328 & 365 & 71 & 20 & 17 & 1.9 & 35 \\
\hline 13 & $07-31-86$ & 270 & 232 & 332 & 345 & 75 & 21 & 15 & 1.7 & 36 \\
\hline 14 & $07-28-88$ & 230 & - & 335 & 338 & 52 & 24 & 41 & 2.7 & 53 \\
\hline 17 & $09-17-79$ & 240 & 190 & 344 & 385 & 60 & 23 & 29 & 2.7 & 58 \\
\hline 19 & $08-15-78$ & 170 & 140 & 200 & 215 & 43 & 14 & 11 & 1.3 & 23 \\
\hline 21 & $01-12-78$ & 200 & 150 & 255 & 233 & 57 & 13 & 17 & 3.3 & 26 \\
\hline 23 & $08-11-77$ & 150 & 140 & 166 & 174 & 40 & 13 & 3.9 & 1.0 & 12 \\
\hline 24 & $10-08-80$ & 170 & 170 & 193 & 211 & 43 & 14 & 5.8 & 0.8 & 10 \\
\hline 26 & $07-18-78$ & 160 & 140 & 168 & 171 & 45 & 11 & 4.0 & .6 & 11 \\
\hline 27 & $01-08-80$ & 240 & 190 & 288 & 302 & 69 & 17 & 14 & 1.2 & 39 \\
\hline 30 & $08-04-87$ & 220 & 157 & 351 & 341 & 54 & 20 & 46 & 2.2 & 47 \\
\hline 31 & $06-10-81$ & 280 & 200 & 409 & 481 & 75 & 22 & 46 & 3.8 & 49 \\
\hline 32 & $09-27-79$ & -- & -- & -- & -- & -- & - & -- & -- & -- \\
\hline 33 & $02-05-79$ & 98 & 82 & 112 & 122 & 27 & 7.4 & 3.5 & 1.0 & 16 \\
\hline 34 & $07-14-78$ & 260 & 160 & 495 & 531 & 72 & 20 & 75 & 6.7 & 88 \\
\hline 35 & $01-21-81$ & 97 & 82 & 115 & 104 & 27 & 7.1 & 4.0 & .8 & 17 \\
\hline 36 & $09-07-84$ & 180 & -- & 281 & 294 & 39 & 21 & 34 & 2.0 & 28 \\
\hline 38 & $09-13-88$ & 270 & -- & 368 & 371 & 70 & 24 & 32 & 4.4 & 78 \\
\hline \multicolumn{11}{|c|}{67} \\
\hline
\end{tabular}


Table 2.--Physical and chemical characteristics of streams during low flow, 1974-89--Cont inued

\begin{tabular}{|c|c|c|c|c|c|c|c|c|c|c|}
\hline $\begin{array}{c}\text { site } \\
\text { number }\end{array}$ & $\begin{array}{c}\text { Date } \\
\text { of } \\
\text { sample }\end{array}$ & $\begin{array}{l}\text { Chlo- } \\
\text { ride, } \\
\text { dis- } \\
\text { solved } \\
\text { (mg/L } \\
\text { as Cl) }\end{array}$ & $\begin{array}{l}\text { rluo- } \\
\text { ride: } \\
\text { dis- } \\
\text { solved } \\
\text { (mg/L } \\
\text { as } F \text { ) }\end{array}$ & $\begin{array}{l}\text { sillca, } \\
\text { dis- } \\
\text { solved } \\
(\mathrm{mg} / \mathrm{L} \\
\mathrm{as} \\
\left.\mathrm{siO}_{2}\right)\end{array}$ & $\begin{array}{c}\text { Arsenlc, } \\
\text { dis- } \\
\text { solved } \\
\text { ( } \mu \mathrm{g} / \mathrm{L} \\
\text { as As) }\end{array}$ & $\begin{array}{l}\text { Barlum, } \\
\text { dis- } \\
\text { solved } \\
\text { ( } \mu \mathrm{g} / \mathrm{L} \\
\text { as } \mathrm{Ba} \text { ) }\end{array}$ & $\begin{array}{c}\text { Cadmlum, } \\
\text { dls- } \\
\text { solved } \\
\text { ( } \mu g / \mathrm{L} \\
\text { as Cd) }\end{array}$ & $\begin{array}{l}\text { Chro- } \\
\text { mium. } \\
\text { dis- } \\
\text { solved } \\
(\mu g / L \\
\text { as Cr) }\end{array}$ & $\begin{array}{l}\text { Cobalt, } \\
\text { dls- } \\
\text { solved } \\
\text { ( } \mu \text { g/L } \\
\text { as Co) }\end{array}$ & $\begin{array}{l}\text { Copper, } \\
\text { dis- } \\
\text { solved } \\
\text { ( } \mu \text { giL } / \mathrm{L} \\
\text { as Cu) }\end{array}$ \\
\hline 1 & $09-28-76$ & 2.6 & 0.1 & 10 & -- & -- & -- & -- & - & -- \\
\hline 3 & $02-23-78$ & 1.4 & $<.1$ & 12 & -- & -- & - & -- & -- & -- \\
\hline 4 & $09-01-76$ & 2.7 & .1 & 6.2 & -- & -- & -- & -- & -- & -- \\
\hline 5 & $11-05-81$ & 1.3 & .1 & 2.3 & 1 & 14 & $<1$ & 10 & 1 & 2 \\
\hline 7 & $06-16-77$ & 2.4 & $<.1$ & 5.2 & -- & -- & -- & - & -- & -- \\
\hline 8 & $02-14-77$ & 4.3 & .2 & 8.9 & -- & -- & -- & -- & - & -- \\
\hline 9 & $09-16-76$ & 1.9 & $<.1$ & 5.2 & -- & -- & -- & -- & -- & -- \\
\hline 11 & $09-16-81$ & 3.9 & $<.1$ & 6.7 & 2. & 100 & $<1$ & 10 & 1 & 4 \\
\hline 12 & $12-15-81$ & 30 & .2 & 7.2 & 1 & 54 & $<1$ & $<10$ & $<1$ & $<1$ \\
\hline 13 & $07-31-86$ & 31 & .2 & 13 & -- & -- & -- & - & -- & -- \\
\hline 14 & $07-28-88$ & 50 & .3 & .73 & -- & -- & -- & -- & -- & -- \\
\hline 17 & $09-17-79$ & 52 & .2 & 4.1 & -- & -- & -- & -- & -- & -- \\
\hline 19 & $08-15-78$ & 20 & .1 & 4.2 & -- & -- & -- & -- & -- & -- \\
\hline 21 & $01-12-78$ & 51 & .1 & 9.1 & $<1$ & $<100$ & $<2$ & -- & -- & 6 \\
\hline 23 & $08-11-77$ & 4.7 & .1 & 6.7 & -- & -- & -- & -- & -- & -- \\
\hline 24 & $10-08-80$ & 5.6 & .2 & 10 & 3 & 30 & 1 & 20 & 0 & 1 \\
\hline 26 & $07-18-78$ & 4.3 & .1 & 8.8 & 1 & $<100$ & -- & 2 & -- & $<2$ \\
\hline 27 & $01-08-80$ & 23 & .2 & 9.6 & 1 & 70 & 2 & 10 & 0 & 2 \\
\hline 30 & $08-04-87$ & 79 & .3 & 5.5 & 3 & 39 & $<1$ & $<1$ & $<3$ & 2 \\
\hline 31 & $06-10-81$ & 89 & .3 & 1.7 & 1 & 40 & 2 & 10 & 0 & 2 \\
\hline 32 & $09-27-79$ & -- & -- & -- & -- & -- & -- & -- & -- & -- \\
\hline 33 & $02-05-79$ & 6.6 & .1 & 1.1 & -- & -- & -- & -- & - & -- \\
\hline 34 & $07-14-78$ & 130 & .6 & 4.5 & 2 & $<100$ & 5 & -- & -- & 2 \\
\hline 35 & $01-21-81$ & 6.8 & $<.1$ & 1.3 & 1 & 20 & $<1$ & 10 & 0 & 1 \\
\hline 36 & $09-07-84$ & 63 & .2 & 7.5 & -- & -- & -- & -- & -- & -- \\
\hline 38 & $09-13-88$ & 50 & .3 & 2.0 & 1 & 57 & 2 & $<1$ & $<3$ & 2 \\
\hline & & & & & 68 & & & & & \\
\hline
\end{tabular}


Table 2.--Physical and chemical characteristics of streams during low flow, 1974-89--Cont inued

\begin{tabular}{|c|c|c|c|c|c|c|c|c|c|c|}
\hline $\begin{array}{c}\text { Site } \\
\text { number }\end{array}$ & $\begin{array}{l}\text { Date } \\
\text { of } \\
\text { sample }\end{array}$ & $\begin{array}{l}\text { Iron, } \\
\text { dis- } \\
\text { solved } \\
\text { ( } \mu \mathrm{g} / \mathrm{L} \\
\text { as } \mathrm{Fe})\end{array}$ & $\begin{array}{l}\text { Lead, } \\
\text { dis- } \\
\text { solved } \\
\text { ( } \mu g / L \\
\text { as } P b)\end{array}$ & $\begin{array}{l}\text { Manga- } \\
\text { nesee, } \\
\text { dis- } \\
\text { solved } \\
\text { ( } \mu \text { gg/L } \\
\text { as Mn) }\end{array}$ & $\begin{array}{c}\text { Mercury, } \\
\text { dis- } \\
\text { solved } \\
(\mu g / L \\
\text { as } \mathrm{Hg})\end{array}$ & $\begin{array}{l}\text { stron- } \\
\text { tium, } \\
\text { dis- } \\
\text { solved } \\
\text { ( } \mu \text { g /L } \\
\text { as } S r)\end{array}$ & $\begin{array}{l}21 n c, \\
\text { dis- } \\
\text { solved } \\
\text { ( } \mu g / L \\
\text { as } 2 n)\end{array}$ & $\begin{array}{l}\text { Sele- } \\
\text { nium, } \\
\text { dis- } \\
\text { solved } \\
\text { ( } \mu g / L \\
\text { as } \mathrm{Se} \text { ) }\end{array}$ & $\begin{array}{l}\text { Nickel, } \\
\text { dis- } \\
\text { solved } \\
\text { ( } \mu g / L \\
\text { as N1) }\end{array}$ & $\begin{array}{l}\text { Sllver, } \\
\text { dis- } \\
\text { solved } \\
\text { ( } \mu g / \mathrm{L} \\
\text { as Ag) }\end{array}$ \\
\hline 1 & $09-28-76$ & -- & -- & - & - & -- & - & - & -- & -- \\
\hline 3 & $02-23-78$ & - & - & - & -- & - & - & - & - & -- \\
\hline 4 & $09-01-76$ & - & - & - & -- & -- & -- & -- & -- & -- \\
\hline 5 & $11-05-81$ & 8 & 1 & $<1$ & 0.7 & -- & 33 & $<1$ & 1 & $<1.0$ \\
\hline 7 & $06-16-77$ & - & - & - & -- & -- & -- & -- & -- & - \\
\hline 8 & $02-14-77$ & -- & - & - & -- & -- & -- & -- & - & - \\
\hline 9 & $09-16-76$ & -- & - & -- & -- & - & - & -- & - & -- \\
\hline 11 & $09-16-81$ & 50 & 1 & 40 & $<.1$ & -- & 20 & $<1$ & 1 & $<1.0$ \\
\hline 12 & $12-15-81$ & 27 & $<1$ & 32 & $<.1$ & -- & 9 & $<1$ & 1 & $<1.0$ \\
\hline 13 & $07-31-86$ & - & -- & - & - & -- & - & - & - & -- \\
\hline 14 & $07-28-88$ & - & -- & - & - & -- & -- & -- & - & -- \\
\hline 17 & $09-17-79$ & -- & -- & -- & -- & -- & - & -- & -- & -- \\
\hline 19 & $08-15-78$ & -- & -- & - & -- & -- & - & - & -- & -- \\
\hline 21 & $01-12-78$ & 100 & 20 & 30 & $<.5$ & -- & $<20$ & $<1$ & -- & -- \\
\hline 23 & $08-11-77$ & -- & -- & -- & -- & -- & -- & - & -- & -- \\
\hline 24 & $10-08-80$ & 0 & 0 & 1 & .1 & - & 6 & 0 & 0 & 0 \\
\hline 26 & $07-18-78$ & 30 & 3 & $<10$ & .5 & -- & $<20$ & $<1$ & -- & -- \\
\hline 27 & $01-08-80$ & 30 & 0 & 20 & .1 & - & 50 & 0 & 1 & 0 \\
\hline 30 & $08-04-87$ & 12 & $<5$ & 8 & $<.1$ & 390 & 30 & $<1$ & $<1$ & $<1.0$ \\
\hline 31 & $06-10-81$ & 10 & 0 & 10 & $<.1$ & -- & 20 & 0 & 5 & 0 \\
\hline 32 & $09-27-79$ & -- & -- & -- & -- & -- & - & -- & -- & - \\
\hline 33 & $02-05-79$ & -- & -- & -- & -- & - & -- & -- & -- & -- \\
\hline 34 & $07-14-78$ & 20 & -- & 50 & .5 & - & 20 & $<1$ & -- & -- \\
\hline 35 & $01-21-81$ & $<10$ & 0 & $<1$ & $<.1$ & -- & 6 & 0 & 0 & 0 \\
\hline 36 & $09-07-84$ & -- & - & -- & -- & -- & -- & -- & -- & -- \\
\hline 38 & $09-13-88$ & 8 & $<5$ & 5 & $<.1$ & 450 & 9 & $<1$ & 2 & $<1.0$ \\
\hline
\end{tabular}


Table 3.--Median values of selected chemical and physical characteristics of ground water, by hydrologic province and aquifer

[Analyses by U.S. Geological Survey. mg/L, milligrams per liter; $18 / \mathrm{L}$, micrograms per 1 iter; <, less than; --, no analysis made]

\begin{tabular}{|c|c|c|c|c|c|c|c|c|}
\hline Source & $\begin{array}{c}\text { Number } \\
\text { of } \\
\text { analyses }\end{array}$ & $\begin{array}{c}\text { Alka- } \\
1 \text { inity } \\
\text { (mg/L } \\
\text { as } \\
\mathrm{CaCO}_{3} \text { ) }\end{array}$ & $\begin{array}{l}\text { Boron, } \\
\text { total } \\
\text { recov- } \\
\text { erable } \\
\text { ( } \mu \mathrm{g} / \mathrm{L} \\
\text { as B) }\end{array}$ & $\begin{array}{c}\text { Calcium, } \\
\text { dis- } \\
\text { solved } \\
\text { (mg/L } \\
\text { as Ca) }\end{array}$ & $\begin{array}{l}\text { Chlo- } \\
\text { ride, } \\
\text { dis- } \\
\text { solved } \\
\text { (mg/L } \\
\text { as Cl) }\end{array}$ & $\begin{array}{l}\text { Copper, } \\
\text { total } \\
\text { recov- } \\
\text { erable } \\
\text { ( } \mu g / \mathrm{L} \\
\text { as Cu) }\end{array}$ & $\begin{array}{l}\text { Eluo- } \\
\text { ride, } \\
\text { dis } \\
\text { solved } \\
\text { (mg/L } \\
\text { as } \mathrm{E} \text { ) }\end{array}$ & $\begin{array}{c}\text { Hardness, } \\
\text { total } \\
\text { (mg/L } \\
\text { as } \\
\mathrm{CaCO}_{3} \text { ) }\end{array}$ \\
\hline
\end{tabular}

Hydrologic Province 1

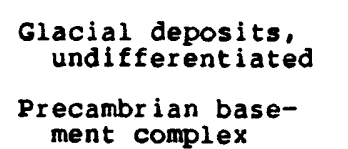

$\begin{array}{llll}15 & 98 & 30 & 28\end{array}$

Hydrologic Province 2 Glacial deposits,
undifferentiated

Precambrian and Cambrian sandstone

$\begin{array}{rrr}8 & 94 & <20 \\ 16 & 113 & 20\end{array}$

1.1

1.1

0.10

7.8

ydrologic Province 3

Glacial deposits.

undifferentiated

Ordovician 1 imestone.

dolomite, and sandstone

4.5

$$
.6
$$

12

.10

15

Precambrian and Cambrian

$23 \quad 181$

160

51

9.8

6

.30

225

sandstone

198

160

60

7.5

.21

240

Hydrologic Province 4

Glacial deposits, undifferentiated

Silurian and Devonian limestone and dolomite

$4 \quad 174<20$

$17 \quad 184$

60

Hydrologic Province 5

Glacial deposits,

undifferent iated

Hydrologic Province 6

Mississippian sandstone and siltstone

Hydrologic Province 7

Glacial deposits,

undifferentiated

$77 \quad 180 \quad 30$

8

177

860

28

258

30
85

43

56

52

4.2

545

2.0

4

.15

172

2.7

5

.52

250

78

14

$<10$

.20

300 
Table 3.--Median values of selected chemical and physical characteristics of ground water, by hydrologic province and aquifer--Cont inued

\begin{tabular}{|c|c|c|c|c|c|c|c|c|}
\hline Source & $\begin{array}{l}\text { Number } \\
\text { of } \\
\text { analyses }\end{array}$ & $\begin{array}{c}\text { Alka- } \\
1 \text { inity } \\
\text { (mg/L } \\
\text { as } \\
\left.\mathrm{CaCO}_{3}\right)\end{array}$ & $\begin{array}{l}\text { Boron, } \\
\text { total } \\
\text { recov- } \\
\text { erable } \\
(\mu \mathrm{g} / \mathrm{L} \\
\text { as } \mathrm{B})\end{array}$ & $\begin{array}{l}\text { Calcium, } \\
\text { dis- } \\
\text { solved } \\
\text { (mg/L } \\
\text { as Ca) }\end{array}$ & $\begin{array}{l}\text { Chlo- } \\
\text { ride, } \\
\text { dis- } \\
\text { solved } \\
\text { (mg/L } \\
\text { as } \mathrm{Cl} \text { ) }\end{array}$ & $\begin{array}{l}\text { Copper, } \\
\text { total } \\
\text { recov- } \\
\text { erable } \\
\text { ( } \mu g / L \\
\text { as Cu) }\end{array}$ & $\begin{array}{l}\text { Fluo- } \\
\text { ride, } \\
\text { dis } \\
\text { solved } \\
\text { (mg/L } \\
\text { as E) }\end{array}$ & $\begin{array}{c}\text { Hardness } \\
\text { total } \\
(\mathrm{mg} / \mathrm{L} \\
\text { as } \\
\left.\mathrm{CaCO}_{3}\right)\end{array}$ \\
\hline \multicolumn{9}{|l|}{ Hydrologic Province 8} \\
\hline $\begin{array}{l}\text { Glacial deposits, } \\
\text { undifferentiated }\end{array}$ & 12 & 156 & 85 & 84 & 15 & 4 & 0.40 & 310 \\
\hline Pennsylvanian sandstone & 33 & 280 & 355 & 80 & 24 & 4 & .40 & 320 \\
\hline \multicolumn{9}{|l|}{ Hydrologic Province 9} \\
\hline $\begin{array}{l}\text { Glacial deposits, } \\
\text { undifferentiated }\end{array}$ & 4 & 193 & $<20$ & 56 & 2.8 & 5.5 & .15 & 215 \\
\hline $\begin{array}{l}\text { Mississipplan sandstone } \\
\text { and siltstone }\end{array}$ & 31 & 274 & 65 & 75 & 16 & 3 & .50 & 290 \\
\hline \multicolumn{9}{|l|}{ Hydrologic Province 10} \\
\hline $\begin{array}{l}\text { Silurian and Devonian } \\
\text { limestone and dolomite }\end{array}$ & 7 & 243 & 175 & 130 & 18 & 4 & 1.2 & 560 \\
\hline \multicolumn{9}{|l|}{ Hydrologic Province 11} \\
\hline $\begin{array}{l}\text { Glacial deposits, } \\
\text { undifferentiated }\end{array}$ & 18 & -- & -- & $-\infty$ & 72 & 21 & -- & -- \\
\hline $\begin{array}{l}\text { Mississippian sandstone } \\
\text { and siltstone }\end{array}$ & 3 & 82 & -- & 68 & -- & 3 & - & 420 \\
\hline \multicolumn{9}{|l|}{ Hydrologic Province 12} \\
\hline $\begin{array}{l}\text { Glacial deposits, } \\
\text { undifferentiated }\end{array}$ & 3 & 144 & -- & 210 & 2,180 & -- & .60 & 633 \\
\hline Pennsylvanian sandstone & 11 & 156 & -- & 315 & 620 & -- & .45 & 935 \\
\hline $\begin{array}{l}\text { Mississipplan sandstone } \\
\text { and siltstone }\end{array}$ & 3 & 219 & -- & 130 & 660 & - & .70 & 450 \\
\hline
\end{tabular}


Table 3.--Median values of selected chemical and physical characteristics of ground water, by hydrologic province and aquifer--Continued

\begin{tabular}{|c|c|c|c|c|c|c|c|}
\hline Source & $\begin{array}{l}\text { Iron, } \\
\text { total } \\
\text { recov- } \\
\text { erable } \\
\text { ( } \mu g / L \\
\text { as } \mathrm{Fe})\end{array}$ & $\begin{array}{l}\text { Lead, } \\
\text { total } \\
\text { recov- } \\
\text { erable } \\
(\mu g / L \\
\text { as } \mathrm{Pb})\end{array}$ & $\begin{array}{l}\text { Sodium, } \\
\text { dis- } \\
\text { solved } \\
\text { (mg/L } \\
\text { as } \mathrm{Na} \text { ) }\end{array}$ & $\begin{array}{l}\text { Solids, } \\
\text { resldue } \\
\text { at } 180 \\
\text { oc, } \\
\text { dis- } \\
\text { solved } \\
\text { (mg/L) }\end{array}$ & $\begin{array}{l}\text { Stron- } \\
\text { tium, } \\
\text { total } \\
\text { recov- } \\
\text { erable } \\
\text { ( } \mu g / L \\
\text { as } S r)\end{array}$ & $\begin{array}{l}\text { sulfate, } \\
\text { dis- } \\
\text { solved } \\
\text { (mg/L } \\
\text { as } \mathrm{SO}_{4}\end{array}$ & $\begin{array}{l}\text { Zinc, } \\
\text { total } \\
\text { recov- } \\
\text { erable } \\
\text { ( } \mu g / L \\
\text { as } z r)\end{array}$ \\
\hline \multicolumn{8}{|l|}{ Hydrologic Province 1} \\
\hline $\begin{array}{l}\text { Glacial deposits, } \\
\text { undifferentiated }\end{array}$ & 220 & 6.5 & 2.4 & 127 & 68 & 6.6 & 83 \\
\hline $\begin{array}{l}\text { Precambrian base- } \\
\text { ment complex }\end{array}$ & 275 & $<5$ & 8.0 & 174 & 130 & 6.5 & 120 \\
\hline \multicolumn{8}{|l|}{ Hydrologic Province 2} \\
\hline $\begin{array}{l}\text { Glacial deposits, } \\
\text { undifferentiated }\end{array}$ & 400 & 13 & 2.0 & 106 & 50 & 6.4 & 60 \\
\hline $\begin{array}{l}\text { Precambrian and Cambrian } \\
\text { sandstone }\end{array}$ & 180 & $<5$ & 8.0 & 150 & 120 & 7.5 & 100 \\
\hline \multicolumn{8}{|l|}{ Hydrologic Province 3} \\
\hline $\begin{array}{l}\text { Glacial deposits, } \\
\text { undifferentiated }\end{array}$ & 3,500 & 18 & .9 & 31 & 52 & 8.9 & 330 \\
\hline $\begin{array}{l}\text { ordovician limestone, } \\
\text { dolomite, and sandstone }\end{array}$ & $725^{\circ}$ & $<5$ & 11.7 & . 296 & 335 & 18 & 35 \\
\hline $\begin{array}{l}\text { Precambrian and Cambrian } \\
\text { sandstone }\end{array}$ & 240 & $<5$ & 4.0 & 242 & 425 & 26 & $<20$ \\
\hline \multicolumn{8}{|l|}{ Hydrologic Province 4} \\
\hline $\begin{array}{l}\text { Glaclal deposits, } \\
\text { undifferentiated }\end{array}$ & 920 & 5 & 2.6 & 165 & 109 & 4.9 & 28 \\
\hline $\begin{array}{l}\text { Silurian and Devonian } \\
\text { limestone and dolomite }\end{array}$ & 710 & 7 & 3.6 & 291 & 410 & 14 & 80 \\
\hline \multicolumn{8}{|l|}{ Hydrologic Province 5} \\
\hline $\begin{array}{l}\text { Glacial deposits, } \\
\text { undifferentiated }\end{array}$ & 240 & 7 & 2.9 & 207 & 60 & 14 & 150 \\
\hline \multicolumn{8}{|l|}{ Hydrologic Province 6} \\
\hline $\begin{array}{l}\text { Mississippian sandstone } \\
\text { and siltstone }\end{array}$ & 2,300 & -- & 310 & 1,300 & $-\infty$ & 111 & -- \\
\hline \multicolumn{8}{|l|}{ Hydrologic Province 7} \\
\hline $\begin{array}{l}\text { Glacial deposits, } \\
\text { undifferentiated }\end{array}$ & 1,300 & 7 & 6.3 & 353 & 150 & 33 & 120 \\
\hline
\end{tabular}


Table 3.--Median values of selected chemical and physical characteristics of ground water, by hydrologic province and aquifer--Cont inued

\begin{tabular}{|c|c|c|c|c|c|c|c|}
\hline Source & $\begin{array}{l}\text { Iron, } \\
\text { total } \\
\text { recov- } \\
\text { erable } \\
(\mu g / L \\
\text { as } \mathrm{Fe})\end{array}$ & $\begin{array}{l}\text { Lead, } \\
\text { total } \\
\text { recov- } \\
\text { erable } \\
(\mu g / L \\
\text { as } \mathrm{Pb})\end{array}$ & $\begin{array}{l}\text { Sodium, } \\
\text { dis- } \\
\text { solved } \\
\text { (mg/L } \\
\text { as Na) }\end{array}$ & $\begin{array}{l}\text { Solids, } \\
\text { residue } \\
\text { at } 180 \\
\text { oc, } \\
\text { dis- } \\
\text { solved } \\
\text { (mg/L) }\end{array}$ & $\begin{array}{l}\text { Stron- } \\
\text { tium, } \\
\text { total } \\
\text { recov- } \\
\text { erable } \\
(\mu g / L \\
\text { as } S r)\end{array}$ & $\begin{array}{l}\text { Sulfate, } \\
\text { dis- } \\
\text { solved } \\
\text { (mg/L } \\
\text { as } \mathrm{SO}_{4}\end{array}$ & $\begin{array}{l}\text { zinc, } \\
\text { total } \\
\text { recov- } \\
\text { erable } \\
(\mu g / L \\
\operatorname{as~} 2 r)\end{array}$ \\
\hline \multicolumn{8}{|l|}{ Hydrologic Province 8} \\
\hline $\begin{array}{l}\text { Glacial deposits, } \\
\text { undifferentiated }\end{array}$ & 600 & 14 & 24 & 500 & 595 & 125 & 30 \\
\hline Pennsylvanian sandstone & 1,400 & 14 & 40 & 558 & 698 & 81 & 25 \\
\hline \multicolumn{8}{|l|}{ Hydrologic Province 9} \\
\hline $\begin{array}{l}\text { Glacial deposits, } \\
\text { undifferentiated }\end{array}$ & 1,430 & 6.5 & 5.8 & 250 & 205 & 26 & 230 \\
\hline $\begin{array}{l}\text { Mississippian sandstone } \\
\text { and siltstone }\end{array}$ & 1,400 & 6 & 16 & 362 & 590 & 40 & 20 \\
\hline \multicolumn{8}{|l|}{ Hydrologic Province 10} \\
\hline $\begin{array}{l}\text { Silurian and Devonian } \\
\text { limestone and dolomite }\end{array}$ & 270 & $<5$ & 24 & 767 & 20,500 & 265 & 60 \\
\hline \multicolumn{8}{|l|}{ Hydrologic Province 11} \\
\hline $\begin{array}{l}\text { Glacial deposits, } \\
\text { undifferentiated }\end{array}$ & 15,000 & 450 & - & 430 & -- & -- & -- \\
\hline $\begin{array}{l}\text { Mississippian sandstone } \\
\text { and siltstone }\end{array}$ & 150 & -- & 8,200 & 27,100 & -- & 3,100 & 2,200 \\
\hline \multicolumn{8}{|l|}{ Hydrologic Province 12} \\
\hline $\begin{array}{l}\text { Glacial deposits, } \\
\text { undifferentiated }\end{array}$ & -- & -- & 1,200 & 4,260 & -- & 290 & -- \\
\hline Pennsylvanian sandstone & -- & -- & 350 & 2,270 & -- & 830 & -- \\
\hline $\begin{array}{l}\text { Mississippian sandstone } \\
\text { and siltstone }\end{array}$ & 7.850 & -- & 640 & 2,100 & -- & 400 & -- \\
\hline
\end{tabular}

